NBER WORKING PAPER SERIES

\title{
EMIGRATION DURING THE FRENCH REVOLUTION: CONSEQUENCES IN THE SHORT AND LONGUE DURÉE
}

\author{
Raphaël Franck \\ Stelios Michalopoulos \\ Working Paper 23936 \\ http://www.nber.org/papers/w23936 \\ NATIONAL BUREAU OF ECONOMIC RESEARCH \\ 1050 Massachusetts Avenue \\ Cambridge, MA 02138 \\ October 2017
}

We would like to thank Sascha Becker, Davide Cantoni, Guillaume Daudin, Melissa Dell, Oded Galor, Paola Giuliano, Moshe Hazan, Ruixue Jia, Oren Levintal, Omer Moav, Ben Olken, Elias Papaioannou, Gerard Roland, Nico Voigtlaender, David Weil, and Ekaterina Zhuravskaya as well as seminar participants at Brown, Harvard, Harvard Kennedy School of Government, Hebrew University of Jerusalem, NBER Summer Institute Political Economy \& Income Distribution and Macroeconomics Workshop, Northwestern Kellogg, Paris-1, Princeton, Insead, NUS, Hong Kong University of Science and Technology, Sciences-Po, Tel Aviv, IDC Herzliya, Toronto, Warwick, and conference participants at the European Public Choice Society Meeting, the Israeli Economic Association conference, and the Warwick/Princeton conference for valuable suggestions. We thank Bernard Bodinier, Martin Fiszbein, and Nico Voigtlaender for sharing their data. We would also like to thank Nicholas Reynolds for superlative research assistance. All errors are our own responsibility. Stelios Michalopoulos and Raphael Franck have no relevant financial support to disclose in relationship to this project. The views expressed herein are those of the authors and do not necessarily reflect the views of the National Bureau of Economic Research.

NBER working papers are circulated for discussion and comment purposes. They have not been peer-reviewed or been subject to the review by the NBER Board of Directors that accompanies official NBER publications.

(C) 2017 by Raphaël Franck and Stelios Michalopoulos. All rights reserved. Short sections of text, not to exceed two paragraphs, may be quoted without explicit permission provided that full credit, including $\odot$ notice, is given to the source. 
Emigration during the French Revolution: Consequences in the Short and Longue Duree Raphaël Franck and Stelios Michalopoulos

NBER Working Paper No. 23936

October 2017

JEL No. N10,O10,O15

\begin{abstract}
$\underline{\text { ABSTRACT }}$
During the French Revolution, more than 100,000 individuals, predominantly supporters of the Old Regime, fled France. As a result, some areas experienced a significant change in the composition of the local elites whereas in others the pre-revolutionary social structure remained virtually intact. In this study, we trace the consequences of the émigrés' flight on economic performance at the local level. We instrument emigration intensity with local temperature shocks during an inflection point of the Revolution, the summer of 1792, marked by the abolition of the constitutional monarchy and bouts of local violence. Our findings suggest that émigrés have a non monotonic effect on comparative development. During the 19th century, there is a significant negative impact on income per capita, which becomes positive from the second half of the 20th century onward. This pattern can be partially attributed to the reduction in the share of the landed elites in high-emigration regions. We show that the resulting fragmentation of agricultural holdings reduced labor productivity, depressing overall income levels in the short run; however, it facilitated the rise in human capital investments, eventually leading to a reversal in the pattern of regional comparative development.
\end{abstract}

\author{
Raphaël Franck \\ Hebrew University of Jerusalem \\ Department of Economics \\ Mount Scopus \\ Jerusalem 91905 \\ Israel \\ raphael.franck@mail.huji.ac.il \\ Stelios Michalopoulos \\ Brown University \\ Department of Economics \\ 64 Waterman Street \\ Providence, RI 02912 \\ and NBER \\ smichalo@brown.edu
}




\section{Introduction}

Tracing the origins and consequences of major political upheavals occupies an increasing part of the research agenda among economists and political scientists. The Age of Revolution in Europe and the Americas, in particular, has received much attention as these major political disruptions are thought to have shaped the economic and political trajectories of the Western world toward industrialization and democracy. This broad consensus concerning their paramount importance, nevertheless, goes in tandem with a lively debate regarding the exact nature of their consequences. The voluminous literature on the economic legacy of the French Revolution attests to this.

On the one hand, there is a line of research that highlights its pivotal role in ushering the French economy into the modern era. This perspective, which begins with 19th century thinkers of different persuasions such as Thiers (1823-1827), Guizot (1829-1832), and Marx (1843 [1970]) and is continued during the 20 th and 21 st centuries by broadly left-leaning scholars (e.g., Jaurès (1901-1903), Mathiez (1922-1924), Soboul (1962), Hobsbawm (1990), Garrioch (2002), Jones (2002), and Heller (2006)), views the 1789 French Revolution as the outcome of the long rise of the bourgeoisie, whose industrial and commercial interests prevailed over those of the landed aristocracy. These authors, in making their case, stress the benefits from the weakening of the Old Regime as manifested in the abolition of the feudal system, the consolidation of private property, the simplification of the legal system, and the reduction of traditional controls and fiscal hindrances to commerce and industry. However, the scholars, who argue that the reforms brought about by the French Revolution were conducive to economic growth (e.g., Crouzet (2003)), are aware of France's lackluster economic performance during the 19th century vis-à-vis England and Germany, and attribute it to the political upheavals that characterized the country and the violence of the Revolution and Napoleonic Wars.

On the other hand, mostly liberal or conservative intellectuals (e.g., Taine (1876-1893), Cobban (1962), Furet (1978), Schama (1989)) emphasize that France remained largely agricultural vis-à-vis England and Germany until 1914. They argue that the French Revolution was not motivated by differences of economic interests between the nobility and the bourgeoisie, but was rather a political revolution with social and economic repercussions (Taylor (1967), Aftalion (1990)). ${ }^{1}$ They consider that the French Revolution was actually "anticapitalist" contributing to the persistent agricultural character of France during the 19th century. Besides the cost of war and civil conflict, these studies emphasize the development of an inefficient bureaucracy and the adverse impact of changes in land holdings on agriculture.

In this study we attempt to shed some light on the short- and long-run economic conse-

\footnotetext{
${ }^{1}$ Maza (2003) in fact argues that there was no genuine French bourgeoisie in 1789 as none of the politicians deemed to represent the bourgeoisie expressed any consciousness of belonging to such a group.
} 
quences of the French Revolution across départements (the administrative divisions of the French territory). Specifically, we exploit local variation in the weakening of the Old Regime, reflected in the different emigration rates across départements. During the Revolution, more than 100, 000 individuals emigrated to various European countries and the United States (Greer (1951)). Among the émigrés, nobles, clergy members, and wealthy landowners were disproportionately represented.

While the first émigrés left as early as 1789, the majority actually fled France, during and after the summer of 1792 (Taine (1876-1893), Duc de Castries (1966), Bouloiseau (1972), Boisnard (1992), Tackett (2015)), when the Revolution took a radical turn which French historian Georges Lefebvre has called the "Second Revolution" (Lefebvre (1962)). During that summer, following the arrest of King Louis XVI on August 10 and the "September Massacres" in Paris (Caron (1935), Bluche (1992)), the hitherto uneasy coexistence of the monarchy and the revolutionaries came to an abrupt end with the proclamation of the Republic on September 21, 1792. Four months later, King Louis XVI was guillotined.

Our identification strategy exploits local variation in temperature shocks at this inflection point of the French Revolution (i.e., the summer of 1792) to get plausibly exogenous variation in the rate of emigration across départements. The logic of our instrument rests on a well-developed argument in the literature on the outbreak of conflict that links variations in economic conditions to the opportunity cost of engaging in violence. To the extent that temperature shocks decrease agricultural output (which we show to be the case in our historical context), an increase in the price of wheat (the main staple for the French in the $18 t h$ century) ${ }^{2}$ would intensify unrest among the poorer strata of the population, thereby magnifying emigration among the wealthy supporters of the moribund monarchy. Consistent with this argument, we show that, in August and September 1792 , there were more peasant riots in départements that experienced larger temperature shocks. ${ }^{3}$ It is worth pointing out that the temperature shocks in the summer of 1792 are mild compared to other years during the Revolution, thereby suggesting that ordinary income fluctuations at critical junctures may have a persistent effect on subsequent development. Importantly, temperature shocks during the other years of the Revolution predict neither emigration rates nor subsequent economic performance.

Our findings suggest that émigrés have a nonmonotonic impact on comparative economic performance unfolding over the subsequent 200 years. Namely, high-emigration départements have significantly lower GDP per capita during the 19th century but the pattern reverses over the 20th century. Regarding magnitudes, an increase of half a percentage point in the share of

\footnotetext{
${ }^{2}$ On the importance of wheat and bread in France in the 18th century, see, for example, Kaplan (1984) and Kaplan (1996). See also Persson (1999) on grain markets during this period.

${ }^{3}$ Along the same lines, Grosfeld, Sakalli, and Zhuravskaya (2017) find that anti-Jewish pogroms in eastern Europe between 1800 and 1927 occurred when poor harvests coincided with institutional and political uncertainty.
} 
émigrés in the population of a département (which is the mean emigration rate) decreased GDP per capita by $12.7 \%$ in 1860 but increased it by $8.8 \%$ in 2010 .

Pinning down the exact mechanism(s) via which emigration shaped local economic performance is challenging. Thanks to the detailed French historical censuses, we attempt to shed some light on this issue. A significant fraction of the émigrés were landowners so their exodus is likely to have influenced the composition of local landholdings. Using the agricultural census of 1862, we show that high-emigration départements have fewer large landowners and more small ones. Indeed, the size of the average farm in France in 1862 was 23.12 acres, smaller than the average farm of 115 acres in England in 1851 and the average farm of 336.17 acres in the United States in 1860 (Shaw-Taylor (2005), Fiszbein (2016)). ${ }^{4}$ This legacy of fragmented landholdings has remained largely in place in France to this day. Furthermore we show that, during the 19th century, this reduction in the preponderance of large private estates and the development of a small peasantry had a negative impact on agricultural productivity by limiting the adoption of scale-intensive mechanization methods. Moreover, we find that the share of rich individuals in the population of high-emigration départements during the 19th century was significantly smaller compared to regions where few émigrés left. This absence of a critical mass of sufficiently wealthy individuals in the era of capital-intensive modes of production may also explain the slow pace of industrialization in the high-emigration départements during the 19th century.

Interestingly, as early as the middle of the 19th century, these agriculturally lagging départements register slightly higher literacy rates than their richer, agriculturally more productive peers. This modest educational edge widens during the early 20th century, after the French state instituted free and mandatory schooling, eventually translating to higher incomes per capita in the later part of the 20th century. This finding highlights that historical legacies may crucially interact with state-level policies and is consistent with recent studies in developing countries which show that increases in agricultural productivity reduce school attendance by increasing the opportunity cost of schooling (see, e.g., Shah and Steinberg (2015)). By establishing a causal link between the rate of structural transformation across regions in France and the intensity of emigration, we shed new light on an intensely debated topic, that is, the economic legacy of the 1789 Revolution within France. ${ }^{5}$

\footnotetext{
${ }^{4}$ In Appendix Table D.1, we distinguish between French départements and US counties which were above and below the median value of grain production in 1862 and in 1860, respectively. We also provide descriptive statistics excluding French farms below five hectares and US farms below nine acres so as to focus on farmers who were presumably above subsistence levels. This robustness check is motivated by the fact that the 1860 US census does not record plots less than three acres. Across all different metrics, French farms are significantly smaller than the US ones.

${ }^{5}$ To be sure, violence during the French Revolution was rampant and multifaceted. Besides the violence of the crowds which our identification strategy leverages, where groups of people vandalized shops and killed civilians and politicians (e.g., Jacques de Flesselle, Jean-Bertrand Féraud), Gueniffey (2011) discusses the top-down planned annihilation of local populations exemplified by the civil war in the Vendée département, the use of the judicial
} 
Related Literature. Our study relates to the literature on the economic consequences of revolutions and conflict. The latter is voluminous (see, e.g., Blattman and Miguel (2010) for a thorough review) and usually focuses on the impact of these events on the cumulable factors of production. Recent studies have shifted their attention to the institutional legacies of conflict. In this respect, our work is closely related to Acemoglu, Cantoni, Johnson, and Robinson (2011). The latter explores the impact of institutional reform caused by the French occupation of German territories. Consistent with the view that barriers to labor mobility, trade and entry restrictions were limiting growth in Europe, they find that French-occupied territories within Germany eventually experienced faster urbanization rates during the 19 th century. In our case, by focusing on départements within France where the de-jure institutional discontinuities exploited by Acemoglu, Cantoni, Johnson, and Robinson (2011) are largely absent, ${ }^{6}$ we examine whether, conditional on the nationwide consequences of the radical institutional framework brought forward by the French Revolution, the local weakening of the Old Regime, reflected in the differential rates of emigration across départements, influenced local development over a significantly longer horizon. Thus, our study is also closely related to Dell (2012) on the Mexican Revolution. She finds that land redistribution was more intense across municipalities where insurgent activity was higher as a result of droughts on the eve of the Revolution, leading to lower economic performance today. The latter was due to the fact that the Mexican state maintained ultimate control over the redistributed land known as ejidos.

By looking at the impact of emigration across départements, our study also contributes to a growing literature that investigates the economic consequences of disruptions in the societal makeup of a region. Nunn (2008) and Nunn and Wantchekon (2011), for example, explore the consequences of the slave trade for African countries and groups, whereas Acemoglu, Hassan, and Robinson (2011) focus on the impact of the mass execution of Jews during the Holocaust on the subsequent development of Russian cities.

Finally, our research is related to studies by Galor and Zeira (1993) and Galor and Moav (2004), which argue for a nonmonotonic role of equality in the process of development. When growth is driven by physical capital accumulation, a larger share of sufficiently wealthy families would be beneficial to local growth during the 19th century. However, areas with more evenly distributed wealth would experience faster human capital accumulation, translating into better economic outcomes during the 20th and 21st centuries. Consistent with this argument, we show that the preponderance of small landowners in the high-emigration départements goes in tandem

system to assassinate political opponents during the Reign of Terror, and the war launched against foreign countries. Unlike the violence of the crowds, these other types of violence do not seem to have responded to climate-induced temporary income shocks.

${ }^{6}$ See, for example, Soboul (1968) for a discussion regarding the application of the Code Civil and the persistence of local institutions within France during the 19th century. 
with an earlier takeoff in human capital accumulation in these regions.

The rest of the paper is organized as follows. In Section 2 we describe the historical background on emigration and land redistribution during the French Revolution. In Section 3 we describe the data and our empirical methodology. In Section 4 we present our main findings and in Section 5 we discuss some of the potential mechanisms that can account for the observed pattern. In Section 6 we conclude.

\section{Historical Background}

In 1789, on the eve of the Revolution, France was the largest economy in Europe, with approximately 25 million inhabitants and lower wages compared to England (see Labrousse (1933) and Toutain (1987)). Politically, it was a monarchy where King Louis XVI's subjects were divided into three orders: the nobility comprising between 150,000 and 300,000 members, the clergy around 100, 000 members, and the Third Estate (artisans, bankers, lawyers, salesmen, peasants, etc.) made up the rest. This political structure was to end with the Revolution. In Appendix A.1 we briefly discuss its proximate and ultimate causes.

\subsection{Emigration during the French Revolution}

The April 8, 1792, law defined as émigrés all the individuals absent from the département in which they possessed property, and, as a result of the July 27, 1792, law, their property could be seized by the French state. The share of émigrés in the population of each département is our key independent variable. The data were compiled by Greer (1951) from several original governmental accounts. The sources are mostly official publications such as the Liste Générale, par Ordre Alphabétique, des Emigrés de toute la République (1792-1800) (General List in Alphabetical Order of Emigrés throughout the Republic), local lists of émigrés, as well as the list of individuals who received compensation after 1825 for the property they lost during the Revolution. ${ }^{7}$ Greer (1951) lists a total of 129, 091 individuals as émigrés.

The revolutionaries were quick to portray all the émigrés as members of the aristocracy who had prospered on the poverty of French peasants and described them as the living manifestation of the hostility to the Revolution. Emigrés were both chastised for abandoning the fatherland to avoid danger in times of political instability and condemned for joining forces with "foreign tyrants" against the nation to restore a hated political regime. Revolutionaries thus passed a series of laws against émigrés, depriving them of their state-funded pensions in 1790, legislating that emigration was a crime in 1791, and eventually confiscating their property in 1792 . In doing

\footnotetext{
${ }^{7}$ France. Ministère des Finances. Etats Detaillés des Liquidations faites par la Commission d'Indemnité, a l'époque du 31 décembre 1826 en Execution de la Loi du 27 avril 1825, Paris, De l'Imprimerie Royale, 1827.
} 
so, some of the revolutionaries were hoping to redistribute land and create a more egalitarian society, but were disappointed not to see immediate consequences of their policies (e.g., Jones (1988), Vivier (1998)).

The data collected by Greer (1951) on the émigrés during the Revolution paint a more nuanced picture than the rhetoric of the revolutionaries, in terms of both the number of émigrés and their social composition. According to Greer (1951), the median département lost 0.31\% of its 1801 population (the first year for which we have reliable population data). Panel $A$ of Figure 1 displays the intensity of émigrés as a share of the population throughout France, showing substantial spatial variation. Panel $A$ of Table 1 lists the départements with the highest and lowest emigration rates. Moreover, a substantial fraction of émigrés (but not all of them) belonged to the local elites, as can be seen in Panel $B$ of Table 1 for the 69 départements for which such information is available. They were mainly aristocrats and clergymen, as well as wealthy urban dwellers and rural landowners from the Third Estate whose property was confiscated and sold (some even lost the property of the Church that they had acquired in the early stage of the Revolution). ${ }^{8}$ As Panel $C$ of Table 1 shows, the shares of the different types of émigrés are strongly correlated. Some of the commoners who left France were servants of aristocrats and followed their employers abroad. Others were landless peasants or artisans either fleeing for their lives or searching for a better life (see Duc de Castries (1966)).

Revolutionary violence not only took several forms, but also its geographic and social incidence was markedly different across French regions and social groups. The civil war was mostly confined to the southeast and west of France, and was particularly intense in the Vendée département. The Reign of Terror, which entailed the use of the judicial system to assassinate political opponents, was more intense in Paris, Lyon and Marseille (i.e., the three main French cities), as well as in the west of France (Greer (1935), Gueniffey (2011)). ${ }^{9}$ As such, unlike the civil war and the judicial Terror, which were spatially concentrated, emigration was for the contemporaries of the Revolution a spectacular consequence of revolutionary violence that, at the time, seemed to affect all of France. Moreover, while France under the monarchy had experienced civil war in the 16th and 17th centuries and while public executions were common during the 18th century (e.g., Bée (1983), Bastien (2006)), emigration was a specific consequence of the Revolution because it implied the precipitous decline of a previously conspicuous social

\footnotetext{
${ }^{8}$ On average, nobles were richer than peasants, and anecdotal evidence suggests that they possessed more land prior to 1789. Of course, there were exceptions, and the living conditions of some nobles, for instance, those in Brittany (Nassiet (1993)), were not really different from those of the peasants. This can explain why before 1789 , political antagonism also existed within each of the three orders, for example, between minor and great nobles (Furet (1978)). It may also help to rationalize why, during the Revolution, some commoners were favorable to a constitutional monarchy (e.g., Jean-Joseph Mounier) while some aristocrats supported the radical turn of the Revolution (e.g., Louis-Michel Le Peletier de Saint-Fargeau).

${ }^{9}$ Greer (1935) reports that there were less than 10 executions in 27 départements during the Terror.
} 
and political group. ${ }^{10}$ In this respect, emigration also differed from the violence stemming from the civil war and the judicial Terror, which disproportionately affected peasants and workers. ${ }^{11}$

\subsection{The Intensification of Emigration during the "Second Revolution"}

During the summer of 1792, major political upheavals and widespread violence, starting with the imprisonment of Louis XVI and his family in early August and culminating with the proclamation of the republic a few weeks later, signified the unraveling of the House of Bourbon and the abolition of the monarchy. In Appendix A.2 we provide details on the unfolding of these events. Many historical anecdotes describe how emigration accelerated during and immediately after the summer of 1792 (e.g., Taine (1876-1893), Bouloiseau (1972), Tackett (2015)). ${ }^{12}$ For instance, reform-minded aristocrats who had played a political role in the first years of the Revolution, such as the Marquis de Lafayette and the Duc de la Rochefoucauld-Liancourt, left France in August 1792. In fact, Tackett (2015) (p. 215) writes that in September 1792, "conditions had become so frightening that many wealthier families began fleeing Paris (...). Others, however, seem to have concluded that the countryside was even more dangerous than Paris." An additional historical piece of evidence pointing to the intensification of the emigration in the fall of 1792 is the reaction of the British government: it introduced the Aliens Act in the House of Lords on December 19, 1792, in an attempt to regulate the uncontrolled influx of French nationals, which created significant anxiety in governmental circles that feared the presence of revolutionary spies and saboteurs.

Several local historians (listed in Markoff (1996)) explicitly link emigration to local episodes of violence during the summer of 1792. For instance, in Var, a high-emigration département, local violence took the form of several days of rioting in Toulon, between July 28, 1792, and September 10th, 1792, where local revolutionaries targeted aristocrats, military officers, and wheat traders whom they considered hostile to the Revolution (Havard (1911-1913)). Members of these groups fled France for Italy. In Ariège a band of peasants led by a local revolutionary began to ransack and burn castles in late August 1792 (Arnaud (1904)). As a result, many aristocrats, bourgeois, and refractory priests sought refuge in Spain.

\footnotetext{
${ }^{10}$ Many Protestants left France after the revocation of the Edit de Nantes in 1685 by King Louis XIV (Scoville (1953)). However, French Protestants did not hold the political clout of the aristocrats who emigrated, and their exodus did not coincide with a massive political and economic transformation akin to that of the French Revolution.

${ }^{11}$ Greer (1935) estimates (Table 8, pp. 165-166) that peasants and workers made up a combined $59.25 \%$ of the total 16, 594 death sentences during the Terror while the nobles were only $8.25 \%$, clergymen $6.5 \%$, members from the upper middle class $14 \%$ and members from the lower middle class $10.5 \%$ (no status was given to the remaining $1.5 \%$ of individuals sentenced to death). Note that the seemingly low official number of victims obscures the fact that many more people were killed without a trial during the Terror.

${ }^{12}$ Arguably, some émigrés had fled France before the summer of 1792. For instance, the Count of Artois, who would become King Charles X (r. 1824-1830), left in 1789, and Jean-Joseph Mounier, one of the royalist leaders of the Amis de la Constitution Monarchique (Friends of the Monarchic Constitution), fled in 1790. A few also left in the post-Thermidorian period in 1794-1795.
} 


\subsection{Emigration and Land Redistribution during the Revolution}

The sale of the biens nationaux is considered by some historians as "the most important event of the French Revolution" (Lecarpentier (1908), Bodinier and Teyssier (2000)). Their claim is based on the fact that a significant amount of land was seized and sold by the government under the name of biens nationaux (national goods) during this period. This land belonged to the Church, the émigrés, and the counterrevolutionaries. The property of the Church was first seized by the French revolutionaries to pay off the debts of the French state on November 2, 1789. The property of the émigrés and counterrevolutionaries was also confiscated for that purpose three years later. It is not clear, however, whether the French state recovered much from those sales due to its inflationary policies. ${ }^{13}$ In addition, during the French Revolution, property rights were granted on the villages' commons: some of the common land was sold to private individuals while some of it was seized by the municipalities and, later on, leased to peasants (Vivier (1998)).

Land redistribution may have been consequential for the French départements for at least two reasons. First, the amount of land which was seized and sold by the government during the Revolution was significant; Bodinier (1999) estimates that $10 \%$ of land changed hands. Second, even though émigrés were invited to return to France in 1802 by Napoléon Bonaparte, he forbade émigrés from reclaiming their landed property. The loss of their property was made permanent in 1814 when it was reaffirmed by Louis XVIII (Louis XVI's brother). Emigrés (and their descendants) were to be compensated by the April 27, 1825, law, which came to be known as the "milliard des émigrés" since these reparations amounted to nearly one billion French francs (nearly $10 \%$ of the French GDP in 1825 (Maddison (2001))), but not all émigrés eventually received compensation for their losses. Overall, some of the émigrés were able to reconstitute part of their landed estate, whereas others were only able to live a gentry life with modest means, and some became destitute. ${ }^{14}$

Nevertheless, there is no consensus as to who ultimately benefited from the sale of the biens nationaux. Schama (1989) suggests that the redistribution of land was not from the landed elite to peasants, but rather a transfer of property within the landed classes. The members of the groups which were gaining economically before the Revolution and who managed to evade violence

\footnotetext{
${ }^{13}$ For an overview of the successive laws pertaining to the sale of the biens nationaux, see Bodinier and Teyssier (2000). For a specific analysis of the economic consequences of the sale of the Church property, see Finley, Franck, and Johnson (2017). On macroeconomic policies during the French Revolution, see, for example, Sargent and Velde (1995).

${ }^{14}$ Aristocrats like the Marquis de Dreux-Brézé in Sarthe and Barral de Montferrat in Isère emerged financially unscathed from the Revolution (Schama (1989)). The Marquis de Lafayette seemed to have lost a large share of his property and led a more modest life (Furet and Ozouf (1988)). Mme Lalanne, born Dudevant de Villeneuve, solicited her admission to the poor house in Bordeaux (Gironde) that she had founded before the Revolution (Boisnard (1992)). It must be noted that there is no evidence that the émigrés engaged in industrial and service activities after their return; their ideological stance was certainly not conducive to such endeavors (Baldensperger (1924)).
} 
by adopting a revolutionary stance (among them, many relatively wealthy urban bourgeois and small farmers) emerged richer since they bought the landed properties of the Church and the fleeing landed gentry at a low price (see, e.g., Marion (1908), Cobb (1972), Sutherland (2003)). Others argue that the sale of the biens nationaux was detrimental to the living conditions of peasants during the 19th century because it created a small peasantry of subsistence, thereby consolidating the agrarian structure of France and delaying economic modernization (Loutchisky (1897), Lefebvre (1924)). Finally, some contend that the redistribution of land was beneficial to French peasants: they became small-scale agrarian capitalists focused on market production (Ado (1987 [2012])). McPhee (1999), for example, provides anecdotal evidence on small landowners who engaged in wine production in Herault.

Crucially, local monographs on the sale of the biens nationaux suggest that the eventual extent of land redistribution and its beneficiaries crucially depended on the extent of local emigration during the French Revolution. This is, in itself, partly to be expected since the biens nationaux comprised the émigrés' properties. Below, we provide examples revealing the intimate relationship between the change in ownership structure, as a result of the sale of the biens nationaux in four départements, and the share of émigrés in the local population.

First, in Cher, which was the third lowest emigration département ( $0.11 \%$ of the population), Marion (1908) documents that there was very little land parcelization and redistribution, or if there was any, it benefited individuals who were already well off. For instance, in Ivoy-le-Pré (9886 ha, 2, 438 inhabitants), not a single plot of land owned by an émigré was sold, while a large domain was transferred from the abbey of Laurois to a major secular landowner, the local fermier-général (a private tax collector under the Old Regime). Similarly, in Menetou-Râtel (2, 801 ha, 1, 195 inhabitants), only 25 properties were sold, and 13 out of the 17 buyers were already major or medium-size landowners.

Second, in Gironde, which was a close-to-median intensity emigration département $(0.24 \%$ of the population), Marion (1908) shows that the properties owned by the Church and the émigrés were parcelized into several smaller land lots in many rural communes, thereby enabling individuals who were previously landless to acquire some property. For instance, in Lugon-etl'Île-du-Carnay (1094 ha, 947 inhabitants), some well-known merchants and notaries bought land, but most of the buyers of biens nationaux were landless farmers and artisans (i.e., blacksmiths, carpenters, coopers, masons, and shoemakers), who acquired small land plots.

Third, in Nord, an above-median intensity emigration département ( $0.35 \%$ of the population), Lefebvre (1924) provides information for 15 villages in the district of Avesnes, which we report in Table 2. The statistics reveal that large properties were parcelized, and there was a substantial transfer of property from nobles to peasants and urban bourgeois. Moreover, part of 
the land, often commons, whose property was in dispute was acquired by the state, that is, either the central government or the local towns.

Finally, in Ille-et-Vilaine, a relatively high-emigration area $(0.42 \%$ of the département's population), many aristocrats lost a significant part of their properties. The castle and the domain of the Vaurouault family near Saint-Malo, for example, were sold as biens nationaux in 1793. The family bought back the castle at the beginning of the $19 t h$ century but permanently lost the domain to small peasants (Boisnard (1992)). Another famous local aristocratic family that lost some of its land was that of François-René de Chateaubriand, the romantic writer and heir to one of the oldest baronies in Britanny. This unfortunate turn of events for François-René de Chateaubriand's family might explain why he was adamant later in his political career that émigrés should be compensated (Chateaubriand (1847), pp. 517-533).

It is against this background that we interpret the share of émigrés in each département as a proxy for the weakening of the local landed elites of the Old Regime and the extent of land redistribution. Below, we establish the empirical validity of these claims and trace the economic consequences of land parcelization over time.

\section{$3 \quad$ Data and Empirical Methodology}

\subsection{Measures of Income, Workforce, and Human Capital}

To capture the short- and medium-run effects of emigration on income per capita at the département level prior to World War II, we use data on GDP per capita as reconstructed by Combes, Lafourcade, Thisse, and Toutain (2011) and Caruana-Galizia (2013) for 1860, 1901 and 1930. For the post-World War II period, data on income per capita at the département level are not available before 1995, so we use data from the French National Institute of Statistics (INSEE, Institut National de la Statistique et des Etudes Economiques) for 1995, 2000, and 2010. We also construct the value added per worker in the agricultural, industrial, and service sectors combining the data of Combes, Lafourcade, Thisse, and Toutain (2011), who assess the value added in each of these three sectors in 1860, 1930, 1982, and 1990, with the occupational data from the governmental surveys carried out from the 19th century onward (Statistique Générale de la France and INSEE). The descriptive statistics in Table D.2 indicate that the shares of the workforce in the industrial and service sectors grew, respectively, from $21.6 \%$ and $15.3 \%$ in 1860 to $30.1 \%$ and $24.8 \%$ in 1930, indicating that slightly less than half of the working French population was still engaged in agriculture before WWII. However, by 1990, the share of the agricultural workforce had declined considerably, with the industrial and service sectors employing $30.7 \%$ and $60.0 \%$ of the workforce, respectively.

We also explore the effect of emigration during the French Revolution on the evolution of 
human capital from the 19th century until today. For the period before World War II, we take advantage of the data on the literacy of French army conscripts (France - Ministère de la Guerre (1839-1937)). ${ }^{15}$ The data enable us to compute the average share of illiterate conscripts, that is, those who could neither read nor write, by decade between the 1840s and 1930s. Our statistics

in Table D.3 show the overall relatively high levels of literacy in France. Specifically, 26.7\% of French army conscripts in the 1840 s, $16.0 \%$ in the 1870 s, and $5.1 \%$ in the 1930 s could neither read nor write. Our post Word War II measures of human capital rely on the successive population censuses carried out in 1968, 1975, 1982, 1990, 1999, and 2010. They allow us to compute the flow of men between the ages of 16 and 24 in each département who completed high school or had a college degree or both.

\subsection{Emigrés and Temperature Shocks in the Summer of 1792}

The observed relationship between emigration and regional development may reflect omitted variables which could explain both emigration and subsequent economic performance. For instance, if emigration was proportional to the pool of "potential" émigrés, then high-emigration départements would be those with initially many nobles and many wealthy landowners. In other words, since we do not have département-level data before and after the Revolution on the relative size of each order (i.e., the nobility, the clergy, and the Third Estate) observed emigration rates may be mechanically linked to the initial regional stock of the old elite and the extent of land concentration prior to 1789 , thereby biasing our estimates. Moreover, despite the thorough efforts to accurately reconstruct the numbers, (Greer (1951), p.17) acknowledges that his "statistics, cannot pretend to absolute exactitude. They include an irregular margin of error. In a few places it may infringe as much as fifty per cent (e.g., in Var), in others it narrows to insignificance (e.g., in Basses-Alpes)." 16 Another limitation of Greer (1951)'s data is that they do not provide a yearly breakdown on the timing of emigration for each département but only for the 1789-1799 period as a whole.

To overcome these important measurement issues, we leverage the spatial variation in the temperature shocks in the summer of 1792 as a source of variation for the share of émigrés in the population of each département. Our identification strategy is motivated by a strand of literature documenting the effect of climate on human activity and the outbreak of violence. The logic is that abnormal weather conditions cause a temporary decline in agricultural output, that is, a transitory negative income shock for farming-based economies. Such a shock decreases the

\footnotetext{
${ }^{15}$ These data are not subject to selection bias because every Frenchman had to report for military service. However, changes in conscription rules meant that not every man eventually served during the 19th century (Crépin (2009)).

${ }^{16}$ Higonnet (1981) suggests, for example, that there were about 25, 000 noble émigrés instead of 16,431, as estimated by Greer (1951).
} 
opportunity cost of violence which in our historical context can be measured by the intensity of emigration rates across départements. For instance, in Orne in the west of France, a highemigration and high-temperature shock département in the summer of 1792, the villagers of Rai and Corsei ransacked the Castle of Rai on September 23, 1792, demanding that the lord of the manor abandon his feudal rights. ${ }^{17}$

It is not clear when the emigration flows, triggered by the events of the summer of 1792 , stopped. It is possible that emigration in some départements took place over several months because violence continued after the summer of 1792. In this respect, two groups of regions stand out. First, the départements of Deux-Sèvres, Loire-Inférieure, Maine-et-Loire, Morbihan, and Vendée were the locus of the civil war in the west of France (e.g., Tilly (1964), Martin (1987)), and second, the départements of Bouches-du-Rhône, Calvados, Gironde, and Var participated in the Federalist Revolt in 1793 (see, e.g., Johnson (1986)). The common characteristic of these territories was that they experienced high-temperature shocks in the summer of 1792 which triggered a period of prolonged emigration and unrest.

In what follows, we explore the effects of the differential pattern of emigration during the Revolution, which we show to be partly shaped by transitory local weather shocks in the summer of 1792, on the long-term process of development across French départements. Our conjecture is that emigration is likely to have had both medium- and long-run repercussions via the channels of land redistribution and the curtailing of the upper tail of the local wealth distribution. In this respect, it stands to reason that any direct economic impact of the summer shocks of 1792 beyond their effect on emigration rates is unlikely to be quantitatively relevant several decades after the event.

Note. In Appendix $B$, we offer two complementary pieces of evidence regarding the impact of temperature shocks on economic conditions and local violence. First, in Appendix B.1 we show that larger temperature shocks translate into spikes in local wheat prices using data collected by Labrousse, Romano, and Dreyfus (1970) for the 1797-1800 period which covers the latter part of the Revolution (see Figure A.3 and columns (1)-(5) of Table D.5). Second, in Appendix B.2 we use the dataset on peasant revolts assembled by Markoff (1996) to quantitatively establish that abnormal temperatures in the summer of 1792 are systematically related to the incidence of peasant revolts during the "Second Revolution" (see Figure A.1 and columns (6)-(7) of Table D.5).

\footnotetext{
${ }^{17}$ The lord of the manor was Louis-Sébastien Desdouits du Ray, a commoner who had been ennobled thanks to the fortune he had made when working in the Compagnie des Indes (du Motey (1893), pp. 108-109). His children emigrated, and years later, in 1826, he and his wife were compensated as ascendants of émigrés under the April 27, 1825, law for the property losses incurred during the French Revolution (France - Ministère des Finances. Etats Détaillés des Liquidations faites par la Commission d'Indemnité, à l'époque du 1er avril 1826 en Exécution de la Loi du 27 avril 1825, Paris, De l'Imprimerie Royale, 1826. Vol. 2, pp.2-3).
} 


\subsection{Temperature Shocks Construction}

Our temperature data come from the European Seasonal Temperature and Precipitation Reconstruction Project, which was developed by paleoclimatologists at the University of Berne (Luterbacher, Dietrich, Xoplaki, Grosjean, and Wanner (2004), Luterbacher, Dietrich, Xoplaki, Grosjean, and Wanner (2006), Pauling, Luterbacher, Casty, and Wanner (2006)). These are season-specific reconstructions for the 1500-1900 period, at a resolution of 0.5 by 0.5 decimal degrees. These data are assembled using a multiplicity of indirect proxies such as tree rings, ice cores, corals, ocean and lake sediments, as well as historical documentary records. As such, measurement error may be nontrivial. Moreover, climatic records are interpolated over relatively

large areas, resulting in two cells per département on average. ${ }^{18}$ According to the authors, the quality and breadth of the underlying sources improve over time, particularly from the end of the 18th century onward.

We follow Hidalgo, Naidu, Nichter, and Richardson (2010) and Franck (2016) and employ two alternative measures of temperature shocks for the summer of 1792 . First, we use the squared deviation of temperature:

$$
Z_{d, t, s}=\left(\frac{x_{d, t, s}-\bar{x}_{d, s}}{\sigma_{d, s}}\right)^{2},
$$

where the temperature $x_{d, t, s}$ in département $d$ in year $t$ of season $s$ is standardized by the mean $\bar{x}_{d, s}$ and the standard deviation $\sigma_{d, s}$ of temperature in each département $d$ in season $s$, where both the mean and standard deviation are computed over a baseline period. The baseline period which we use to compute $\bar{x}_{d, s}$ and $\sigma_{d, s}$ comprises all the summer temperatures in the 25 years before 1792 (i.e., from 1767 until 1791). As we discuss below, we consider several robustness checks to this baseline specification.

Second, we define the absolute deviation of temperature as:

$$
Z_{d, t, s}=\left|\frac{x_{d, t, s}-\bar{x}_{d, s}}{\sigma_{d, s}}\right|,
$$

Panel $B$ of Figure 1 maps the spatial distribution of the mean temperature in the summer of 1792, while Panel $C$ of Figure 1 portrays the squared deviation of temperature. In Panel $D$ we present these temperature shocks after partialing out the time-invariant geographic controls described below. The observed spatial variation in temperature shocks of Panel $D$ is our source of identification.

\footnotetext{
${ }^{18}$ Départements were designed in 1790 to be of relatively small size so that it would take at most one day of horse travel to reach the département's administrative center from any location in the département. On average, the département's area is $6,000 \mathrm{~km}^{2}$, which is approximately the size of the US state of Delaware.
} 
It is important to note that the summer of 1792 was comparable to the other summers during the Revolution. The descriptive statistics in Table D.4 indeed show that the summer of 1792 is at the median of the summer temperature distribution for the 1788-1799 period, with an average temperature of 17.97, standard deviation 1.36, and a minimum (maximum) temperature of 13.69 (21.82). The temperature in the summer of 1792 was therefore less unusual than the summers of 1788 and 1789 which led to the outbreak of the Revolution. In fact, the descriptive statistics in Table D.4 show that the average temperature shock in the summer of 1792 was milder than any other summer temperature shock during the 1788-1799 period.

\subsection{Confounding Characteristics of Each Département}

\subsubsection{Geographic Characteristics}

In the empirical analysis below, we control for the département's area, land suitability for agriculture, elevation, longitude and latitude. These geographic characteristics may influence both a region's emigration rate as well as its agricultural comparative advantage and hence the pace of industrialization and, ultimately, economic growth. Controlling for longitude and latitude also enables us to account for the location of industries before (and after) the Revolution that were mostly situated in the east and north of France. Moreover, given the importance of temperature shocks in 1792 for our identification strategy (see below), we control for the average temperature in the summer of 1792. In addition, we take into account the distance from each département's main administrative center (chef-lieu) to the coast, the border, and the three largest urban centers (before the French Revolution and to this day), Paris, Lyon, and Marseille. These variables capture the potential confounding effects of the geographic location of the départements, which may have affected emigration intensity and local development via the proximity to trade routes.

\subsubsection{Prerevolutionary Characteristics}

Differences in local pre-1789 development outcomes may have jointly affected emigration during the Revolution and the subsequent evolution of income per capita. To account for these potentially confounding factors, we add the following proxies. First, to capture prerevolutionary levels of human capital, particularly the upper end of the distribution, we use an indicator for the presence of a university in 1700 in the département (Bosker, Buringh, and van Zanden (2013)). Second, we compute the share of the population that subscribed to the Quarto edition of the Encyclopédie in the mid-18th century (Darnton (1973), Squicciarini and Voigtländer (2015)) which also captures the diffusion of the ideas of the Enlightenment within France. Third, we construct the number of mechanical mills in 1789 used in textile production (Bonin and Langlois (1997)). This variable not only accounts for early industrialization but also for prerevolutionary agita- 
tion as a substantial number of riots in France in 1788 and 1789 occurred in textile-producing regions that suffered from the increased competition from English manufacturers after the signature of the Eden Treaty in 1786 (which lowered tariffs between England and France (Mathiez (1922-1924))). ${ }^{19}$ Finally, we add a dummy for the départements which Vivier (1998) singles out as having few commons just before the outbreak of the Revolution and hence more established private property rights over land.

\subsection{Empirical Model}

The effect of emigration during the French Revolution on economic development is estimated using 2SLS. The second stage provides a cross-sectional estimate of the relationship between the share of émigrés in the population in each département during the Revolution and measures of GDP per capita, human capital, and additional economic outcomes at different points in time:

$$
Y_{d, t}=\alpha+\beta E_{d}+\mathbf{X}_{d}^{\prime} \cdot \omega+\varepsilon_{d, t}
$$

where $Y_{d, t}$ represents some proxy of economic performance in département $d$ in year $t, E_{d}$ is the $\log$ of the share of émigrés in the population of département $d, X_{d}^{\prime}$ is a vector of geographical and prerevolutionary characteristics of département $d$, and $\varepsilon_{d, t}$ is an i.i.d. error term for département $d$ in year $t$.

In the first stage, $E_{d}$, the log of the share of émigrés in the population of département $d$ during the French Revolution is instrumented by $Z_{d, 1792}$, the squared (or absolute) deviation of temperature in the summer of 1792 :

$$
E_{d}=\delta_{0}+\delta_{1} Z_{d, 1792}+\mathbf{X}_{d}^{\prime} \cdot \omega+\mu_{d}
$$

where $\mathbf{X}_{d}^{\prime}$ is a vector of geographical and prerevolutionary traits of département $d$ described above.

\section{Results}

\subsection{First Stage: Temperature Shocks in the Summer of 1792 and Emigration}

The first-stage results are reported in Table 3 where the instrument is the squared (absolute) standardized deviation from average temperature in the summer of 1792 in columns (1)-(3) (columns (4)-(6)). In all specifications and irrespective of the inclusion of geographic and historical controls, the estimates reveal that the squared and absolute temperature deviations in the summer

\footnotetext{
${ }^{19}$ On the Eden Treaty, see, for example, Henderson (1957), and on the consequences of the disruption to international trade caused by the revolutionary and Napoleonic Wars, see, for example, Heckscher (1922), Crouzet (1964) and Juhász (2015).
} 
of 1792 are positively and significantly correlated at the $1 \%$ level with variations in the share of émigrés across French départements. This effect is also quantitatively large. In column (3) of Table 3, the beta coefficient equals to 0.549. Put differently, a one-standard-deviation increase in the squared deviation from temperature in the summer of 1792 (0.067) increases the share of émigrés in the population by $0.42 \%$ (relative to a sample mean of $0.47 \%$ and a standard deviation of $0.64 \%$ ). Moreover, the F-statistic of the first stage is equal to 16.88 in the specification where the instrumental variable is the squared deviation of temperature in 1792 (column (3)) and 11.32 in the specification where the instrumental variable is the absolute deviation of temperature in 1792 (column (6)), suggesting that these instruments are not weak. Figure 2 graphs the firststage relationship between the squared deviation from average temperature in the summer of 1792 and the share of émigrés, conditional on geographic characteristics (Panel A) and conditional on geographic and pre-1789 historical characteristics (Panel B).

Note. In Appendix B.3, we provide a series of robustness checks on the uncovered link between temperature shocks in the summer of 1792 and variation in the share of émigrés. These robustness checks have a dual goal. The first is to highlight that consistent with the historical narrative, the temperature shock of the summer of 1792 is the only significant determinant of emigration among all the temperature shocks during the revolutionary period. Specifically, we show that emigration rates are not explained by (i) temperature shocks in the other three seasons of 1792 (Table D.6); (ii) summer temperature deviations between 1788 and 1800 (Table D.7); or (iii) rainfall shocks in the summer of 1792 (Table D.8). We also show that (iv) Conley-corrected standard errors at various distance thresholds provide similar first-stage results (Table D.9); (v) and alternative time windows to standardize the temperature shocks (Table D.10) do not change the patterns found.

Second, in an attempt to strengthen our identification assumption, namely that the weather shock in the summer of 1792 is uncorrelated with preexisting social and economic traits, we gathered salient pre-revolutionary covariates at the département level and tested whether these features predict the 1792 temperature deviation. Such covariates include (i) episodes of violence immediately before (and after) the Revolution; (ii) complaints of the French population in 1789 as expressed in the cahiers de doléances; (iii) human capital before the Revolution proxied by the share of brides and grooms that were able to sign their wedding contracts; (iv) the share of the clergy that was hostile to the Revolution, and (v) the number of famous aristocratic families. All in all, the results in Table D.11 are reassuring. None of these potentially important variables correlates with our instrument, thus suggesting that it is a plausible source of identification for the impact of emigration on regional economic performance in the short and longue durée. 


\subsection{The Effect of the Emigrés on the Economy in the Medium and Long Run}

In this subsection, we explore the impact of emigration during the Revolution on several economic outcomes over time, namely income per capita, sectoral labor productivity, and the composition of the workforce.

\subsubsection{Emigrés and the Evolution of Income per Capita}

The relationship between emigration and income per capita up to World War II is presented in Table 4, where the instrument is the squared deviation from standardized temperature in the summer of 1792 . Table D.12 in Appendix D replicates Table 4 using the absolute deviation from standardized temperature in the summer of 1792. As shown in columns (1), (5), and (9) in Panel A of Table 4, the unconditional OLS relationship between emigration and GDP per capita is negative in 1860 and 1901, and turns positive in 1930 but is insignificant. The relationship between emigration and income per capita in 1860 strengthens and becomes significant when we account for geographical factors in column (2). The 2SLS estimates in columns (3)-(4), (7)(8), and (11)-(12) in Panel A of Table 4 reveal that there is a negative and significant effect of emigration on income per capita in 1860 and 1901 as well as a negative but insignificant effect in 1930, whether we only account for geographic controls or include both geographic and prehistorical controls. A half-percentage-point increase in the share of émigrés in a département decreases GDP per capita by $12.8 \%$ in 1860 and $18.8 \%$ in $1901 .{ }^{20}$ In both Tables 4 and D.12, the coefficient estimates associated with the share of émigrés in the 2SLS regressions are significantly larger than the corresponding OLS ones. Besides measurement error in the share of émigrés resulting in attenuation bias in the OLS coefficients, an additional and perhaps more pertinent explanation for the downward bias of the OLS coefficient arises from the fact that the unobserved initial presence of wealthy landowners and priests in the population of a given département (the stock) and their measured share in the département's population (the flow) are mechanically linked.

An alternative way to assess the negative but eventually vanishing impact of emigration on local economic development during the 19th and early 20th centuries can be seen in Figure D.4 where we take advantage of the data from Bonneuil (1997) on fertility and infant mortality between 1811 and 1901. The fertility rate is computed as the Coale fertility index (Coale (1969)) for each département, while the infant mortality rate is computed as the share of children who

\footnotetext{
${ }^{20}$ Few of our geographic and historical controls are significant in the 2SLS regressions reported in columns (8) and (12). Longitude is positively correlated with income per capita in 1860 and 1901, probably reflecting the fact that départements in the east of France were more industrialized. A lack of commons in the 1780s is also positively correlated with income per capita, which could be expected since commons were detrimental to agricultural productivity. Finally, distance to the coast has a negative impact on income, as landlocked départements could not profit from maritime trade.
} 
died before their first birthday. In Figure D.4 we report the coefficients associated with the share of émigrés in 2SLS regressions (available upon request) where the dependent variable is the Coale fertility index (Panel A) and infant mortality (Panel B). A high share of émigrés has a positive and significant effect on fertility and infant mortality until the 1880s, and no significant impact afterward.

The relationship between emigration and income per capita in the long run is presented in Panel B of Table 4. As shown in columns (1), (5) and (9) unconditionally, emigration during the Revolution has an insignificant positive association with income per capita across départements in 1995, 2000, and 2010. This relationship becomes significantly positive once geographical features are accounted for in columns (2), (6), and (10). Finally, the 2SLS estimates in columns (3)-(4), (7)-(8), and (11)-(12) in Panel B of Table 4 suggest that emigration had a positive effect in the long run. A half-percentage-point increase in emigration increases GDP per capita in 1995 by $8.7 \%$, in 2000 by $9.8 \%$, and in 2010 by $8.8 \% .^{21}$ Similar results are reported in Table D.12 in Appendix D.

Our 2SLS estimates in Tables 4 and D.12 indicate that there was a reversal of the effect of emigration on income per capita: départements with more emigration were poorer until World War I but became richer by the turn of the 21st century. We illustrate this reversal by plotting in Figure 3 the coefficients associated with the share of émigrés in the 2SLS regressions reported in columns (4), (8), and (12) of Panels A and B in Tables 4 and D.12.

Robustness checks. This reversal in the impact of emigration on economic performance is driven neither by a specific group of départements nor by outlier départements with "too few" or "too many" émigrés. In Figure 4, we plot the coefficients from 2SLS regressions on GDP per capita in 1860 and 2010 where we remove one "nuts 1" region at a time. ${ }^{22}$ In Figure 5, we plot the coefficients from 2SLS regressions on GDP per capita in 1860 and 2010, where we remove the top and bottom 1\%,5\%,10\% and 20\% départements in the distribution of the share of émigrés. Under all these alternative permutations, the coefficient associated with the share of émigrés in the 2SLS regressions remains consistently significant: negative in 1860 and positive in 2010.

This pattern is also evident in the reduced-form estimates reported in Table D.7 in Appendix D. Panels A and B of Figure 6 graph the reduced-form relationships between the temperature shock in the summer of 1792 and GDP per capita in 1860 and 2010, respectively. Moreover, the reduced-form regressions in Table D.7 in Appendix D show that no temperature shock in the

\footnotetext{
${ }^{21}$ In the 2SLS regressions, three covariates have a systematic significant effect on GDP per capita in 1995, 2000, and 2010. Specifically, the distance of each département from Paris and Lyon is negatively correlated with income, indicating the importance of these two major urban centers on spatial development. Furthermore we find that the département's area is positively correlated with income, suggesting the presence of scale effects.

${ }^{22}$ The nomenclature of territorial units for statistics (or "nuts") is a standard for referencing administrative divisions within European Union countries. Here we use the first level of "nuts" for France.
} 
summers between 1788 and 1800, other than that of 1792, can explain this reversal. We also show that the sign and statistical significance in the reduced-form relationship between temperature shocks in 1792 and GDP per capita in 1860 and 2010 is robust to using baselines other than the 25 years preceding 1792, that is, using the 50 years before 1792 (1743-1791) or the 1751-1800, 1751-1775, and 1776-1800 periods in Table D.10 in Appendix D.

Finally, in Table D.13, we examine the impact of the social status of émigrés on GDP per capita in 1860 and 2010 by distinguishing between rich émigrés (aristocrats, priests, and upper middle class) and poor émigrés (lower middle class, workers, and peasants). Even though statistics on these social groups of émigrés are only available for 69 out of 86 départements, the 2SLS regression results in Table D.13 are qualitatively similar to those in Table 4 insofar as the shares of rich and poor émigrés have a negative and significant effect on GDP per capita in 1860 and a positive and significant impact on GDP per capita in 2010.

\subsubsection{Emigrés, Labor Productivity, and the Workforce}

This subsection explores the effect of emigration on labor productivity in the different sectors of the economy. In Panel $A$ of Table 5, we examine the impact of emigration on the value added per worker in the agricultural, industrial, and service sectors in 1860, 1930, 1982, and 1990, respectively. The 2SLS regressions in columns (1)-(3) show that emigration had a significantly negative impact on productivity in all three sectors in 1860. The estimates in columns (4)-(6) reveal that there was still a negative effect of emigration on agricultural productivity in 1930. However, in columns (7)-(12), the effect of the share of émigrés on productivity in each sector in 1982 and 1990 is positive and significant.

The negative effect of the share of émigrés on agricultural productivity in the mid-19th century can be partially accounted for by the limited mechanization in agriculture in 1862 in highemigration départements. Specifically, in Table 6 we find that, out of the 15 different categories of agricultural instruments per worker in the agricultural sector, emigration is negatively correlated with 13 of these inputs, and this effect is significant for the quantity of fertilizer and the number of scarifiers, grubbers, searchers, seeders, and tedders. It is also significantly and negatively correlated with the first principal component of all these agricultural tools per worker in the agricultural sector. These results are in line with the view that French agriculture remained relatively backward as a result of the French Revolution. ${ }^{23}$

In Panel $B$ of Table 5, we examine the impact of emigration on the share of the workforce employed in the agricultural, industrial, and service sectors. The 2SLS regressions in columns

\footnotetext{
${ }^{23}$ In regressions available upon request, which are motivated by the study of Rosenthal (1988) on irrigation in the aftermath of the Revolution, we analyze the impact of emigration during the Revolution on the area drained in each department as well as the number of pipe factories in each département in 1856 using the information in Barral (1858). We find that emigration had an insignificant impact on both variables.
} 
(1)-(3) show that emigration had a positive but insignificant impact on the share of the workforce in the agricultural sector in 1860, a positive and significant effect at the $10 \%$ level on the share of the workforce in the service sector, but a negative and significant effect at the $1 \%$ level on the share of the workforce in the industrial sector. This last result suggests that emigration during the French Revolution delayed the structural transformation of France toward the industrial era, in line with the analysis of Cobban (1962). Moreover, the regressions in columns (4)-(6) show that in 1930, emigration still had an insignificant effect on the share of the workforce in the agricultural sector, a negative and significant effect at the $10 \%$ level on the share of the workforce in the industrial sector, and a positive and significant effect at the $5 \%$ level on the share of the workforce in the service sector. Finally, the regressions in columns (7)-(9) show that in 2010, emigration had a negative and significant effect at the $1 \%$ level on the share of the workforce in the agricultural sector as well as a positive and significant effect on the shares of the workforce in the industrial sector at the $5 \%$ level and in the service sector at the $1 \%$ level.

All in all, the evidence in Tables 5 and 6 sheds some light on the sources of the negative impact of emigration on incomes during the 19th century shown in Table 4. It suggests that emigration during the French Revolution disproportionately and inversely affected agricultural productivity up until World War II and slowed down the structural transformation toward industry during the 19th century. Nevertheless, since the second half of the 20th century, highemigration départements have been hosting a more productive workforce in the industrial and service sectors. ${ }^{24}$

\section{Mechanisms}

In this section we explore some potential channels which may account for the negative effect of emigration during the Revolution on the standards of living in the 19th century and its positive effect toward the end of the 20th century. First, we investigate how the absence of émigrés seems to have had an impact on the size and the composition of the local elites during the 19th century. Second, we analyze the impact of émigrés on the landownership structure. Finally, we examine their effect on the evolution of human capital across départements over time.

\subsection{Emigration during the Revolution and the Economic Elites of the 19th Century}

Here we investigate how emigration during the Revolution influenced the size and composition of local elites during the 19th century. The 2SLS estimates in Table 7 focus on electors in the 1839

\footnotetext{
${ }^{24}$ In Table D.14, we examine the impact of emigration during the Revolution on the population in each département (Panel A) as well as in the chef-lieu (i.e., administrative center) of each département (Panel B). We find that emigration during the Revolution has no impact on population density until World War II.
} 
elections under the regime of the July monarchy (1830-1848). At that time, the voting franchise was restricted to men above the age of 25 who could pay 200 francs worth of direct annual taxes. This was a significant amount considering that the average daily wage of bakers in Paris in 1840 was equal to four francs (Chevallier (1887), p.46).

The 2SLS estimates in column (1) of Table 7 show that émigrés had a negative effect on the share of electors in the population in 1839. The presence of a smaller economic elite in high-émigrés areas suggests that the local elites were severely weakened by emigration during the Revolution, leaving these départements with fewer wealthy individuals who could potentially fund the costly investments of industrialization. This finding is in line with the evidence in Table 5, that départements with a large share of émigrés were characterized by both lower productivity and lower employment in the industrial sector. ${ }^{25}$

Moreover, the estimates in Table 7 suggest that emigration had a negative effect on the share of landowners among the electors (column (2)), a positive but insignificant effect on the share of businessmen and professionals (i.e., doctors and lawyers) (columns (3)-(4)), as well as a positive and significant effect on the share of civil servants (column (5)). The finding in column (2) highlights the relative paucity of sufficiently wealthy landowners that may explain the lower agricultural productivity in 1860 in high-emigration départements. We come back to this issue in the next section where we discuss in detail how the composition of agricultural landholdings shaped local development.

The estimate in column (5) of Table 7 shows that in 1839, electors in high-emigration départements were disproportionately drawn from the pool of civil servants. At first, this pattern may seem puzzling, but it is in line with the analysis of Tocqueville (1856) on how the French Revolution contributed to the growth of the French administration and the central state. The increased presence of civil servants in high-emigration départements is corroborated by the estimates in Table D.16, where we show that emigration had a positive and significant effect on the workforce share of civil servants in 1851 and 1866 as well as a positive but insignificant one in 1881. All in all, the evidence suggests that there were relatively more civil servants, and presumably, a more powerful administrative machine, in the départements where the Revolution had been more intense, as proxied by the share of émigrés in the population.

\footnotetext{
${ }^{25}$ In Table D.15, we examine the impact of emigration on local financial development. We proxy the latter by the total value of loans (in French francs) granted by local savings banks and by the number of contracts sealed by notaries in each département, keeping in mind that notaries had, by the second half of the 19th century, lost their central role as financial intermediaries which they had held prior to the Revolution (Hoffman, Postel-Vinay, and Rosenthal (2000)). We find that emigration is negatively correlated with both measures during the 19th century (the effect is, however, only significant on the number of contracts sealed by notaries in 1861). Overall, the results suggest that the negative effect of émigrés on GDP per capita only weakly stemmed from financial underdevelopment.
} 


\subsection{Emigration during the Revolution and the Composition of Agricultural Holdings}

We have already established that in départements with a higher share of émigrés, labor agricultural productivity was significantly lower and fewer rich landowners voted in the elections held in 1839. In this section, we further examine the impact of emigration on the size of agricultural landholdings.

In the agricultural census of 1862, landholdings are categorized in brackets according to their size. The largest landholdings are those in the category above 40 hectares. Given the historical account and the evidence on the composition of the elites, one would expect to find that high-emigration départements have a dearth of large holdings. This is shown to be the case in column (1) in Panel A of Table 8 where the dependent variable is the share of farms above 40 hectares: a one-percentage-point increase in the share of émigrés in the population decreases the share of farms above 40 hectares in 1862 by $1.54 \%$. It is instructive to link this finding with the work of David (1975) (pp.221-231) on the adoption of the mechanical reaper for harvesting wheat in 1854-1857 in the United States. He finds that the mechanical reaper was only economically viable for farms larger than roughly 20 hectares. In 1862 only $13 \%$ of farms were above 20 hectares in the median French département, while $52.9 \%$ and $58.5 \%$ of farms were above that threshold in the United States in 1860 and England in 1851 (Grigg (1992)), respectively. Moreover, as we show in column (2), French départements that experienced a larger exodus during the Revolution had systematically fewer farms above this scale-efficient size. Namely, we find that a one-percentage-point increase in the share of émigrés in the population decreased the share of farms above 20 hectares in 1862 by $0.87 \%$. This absence of sufficiently large landholdings echoes the findings in Table 6 regarding the delayed mechanization of French agriculture in high-emigration départements.

In columns (3)-(5) in Panel A of Table 8, our dependent variables are the ratio of the number of farms of 40 hectares and above to the number of farms below 10 hectares in 1862 and the ratio of the number of farms of 50 hectares and above to the number of farms below 10 hectares in 1929 and 2000. These variables are meant to capture the relative abundance of large- to small-sized farms within a département. Over the last 150 years, regions in France where emigration was more intense during the 1789 Revolution consistently feature an agricultural landscape dominated by small- to medium-sized farmers and a scarcity of large ones. ${ }^{26}$ The demise of large landed elites and the creation of a small peasantry mainly working for subsistence, at least until World War II, was part of the legacy of the émigrés' flight during the French Revolution. Panels C and D of Figure 6 plot the residuals of the reduced-form regressions between the summer of 1792

\footnotetext{
${ }^{26}$ Additional results available upon request show that the share of émigrés had a positive but insignificant effect on the total number of farms and total number of farms per inhabitant in 1862.
} 
temperature shock and the ratio of farms above 40 hectares to farms below 10 hectares in 1862 and between the summer of 1792 temperature shock and the share of farms above 20 hectares in 1862.

It is interesting to compare the results in Panel A of Table 8 to those of Finley, Franck, and Johnson (2017), who find that the auctions of Church land during the Revolution are positively correlated with land concentration during the mid-19th century (and hence, with higher investments in agriculture). Their rationale is that the auctions of Church property, which took place in the early stages of the Revolution before the summer of 1792, mainly entailed a transfer of land from the Church to members of the wealthier sections of the local society. In our context, the extent to which the local elite might eventually have been able to benefit from the Church property would depend on the extent of emigration during the Revolution. In other words, if our conjecture is right, one would expect to find that the negative impact of emigration on land concentration to be magnified in areas where more Church land was auctioned. This is what we find in Panel B of Table 8, where we run reduced-form regressions on the 67 départements for which we have information on the share of the Church property sold during the Revolution (Bodinier and Teyssier (2000)). Specifically, we control for the latter and add the interaction term between the share of Church land sold in each département and the temperature shocks in the summer of 1792. In all the regressions, we find, in line with Finley, Franck, and Johnson (2017), that the share of the Church property sold in each département is positively correlated with the presence of large estates, and more importantly for our analysis, that the interaction term is negative and highly significant. The direct effect of temperature shocks also remains precisely estimated, suggesting that emigration did lead to a decline in the share of large landowners even in the absence of Church land redistribution. Its impact, nevertheless, was significantly stronger precisely where more Church land was sold.

One may naturally wonder why market forces did not "correct" this inefficient size of small landholdings over time. In other words, why did this lopsided ownership structure in agriculture survive when one would expect consolidation to take place? Although a thorough exploration of this subject would take us beyond the confines of the current study, we venture a tentative explanation below.

First of all, it must be noted that there was no deliberate, official policy designed specifically to perpetuate the fragmentation of landownership status quo during the 19th century (Agulhon, Désert, and Specklin (1976)). Nevertheless, the existence of the octrois might help to explain why the tendency toward consolidation might have been less pronounced. The octrois were the local taxes levied on almost all goods entering towns (e.g., meat, wine, fruits, vegetables, coal, etc.) and, de facto, functioned as internal trade barriers within France (before and after 1789, as they 
were only finally abolished in 1943). These octrois favored small local farmers whose production would be exempt from paying them. Throughout the 19th century, the central government progressively reined in the ability of towns to levy octrois, and on December 29, 1897, the French Parliament passed a law which came into effect on January 1, 1901, dictating a substantial decrease in octrois rates. This law, which was the outcome of the lobbying from "progressives" who sought to improve citizens' health by promoting the consumption of wine as opposed to liquor, benefited large wine producers in the south, who were able to produce cheap wine in large quantities. The law thus crowded out small wine producers who successfully lobbied for costly anti-competitive legislation which was adopted in 1905 to reduce fraud and adulteration in the wine market and which, de facto, protected small producers of local wine (Franck, Johnson, and Nye (2014)). This example suggests that local demand for barriers to entry would be stronger in regions dominated by small landowners since competition from large farmers would be damaging to their revenues. In fact this is what we find in Table D.17: départements with a larger share of émigrés had in 1875 more French towns ("communes") which were protected by octrois taxes, and the magnitude of these taxes for various products were also likely to be significantly higher.

Another potential explanation for the negative impact of emigration on agricultural productivity may stem from the positive effect of emigration on the share of commons in each département in 1863, as can be seen in column (6) in Panel A of Table 8. A one-percentage-point increase in the share of émigrés in the population increases by $1.72 \%$ the share of commons in 1863 . As discussed by Vivier (1998), there is ample anecdotal evidence that the central state and the local governments seized the commons during the Revolution in places where there were more émigrés. In turn, the local governments leased those lands to farmers for a limited number of years. Such leases in agriculture may have had a negative effect on agricultural productivity by limiting investments in machinery and promoting intensive production methods which would be damaging for land productivity in the long run. ${ }^{27}$

The evidence in this section provides a possible foray into understanding why local incomes were depressed during the 19th century in regions that émigrés left in large numbers. Can the same economic forces, reflected in the distribution of agricultural landholdings, help to explain the takeoff of these initially lagging regions? This is what we ask below.

\footnotetext{
${ }^{27}$ French towns ("communes") could lend their land under ordinary leases or grant longtime leases. The "ordinary" leases were limited to 9 years in 1791 for all communes, but exceptions could be granted by the national administration. The 9 -year limit was soon extended to 18 years. Moreover, in 1859, the law was changed so that the ordinary leases of the communes were a minimum of 9 years and a maximum of 27. Furthermore, communes had the right to deliver lifelong leases on commons.
} 


\subsection{Emigration during the Revolution and Human Capital Accumulation}

This section examines whether the positive effect of emigration on the standards of living in the long run can be explained by its impact on the evolution of human capital accumulation of each département before and after World War II.

\subsubsection{The Effect of Emigrés on Human Capital Accumulation}

For the period before World War II, our empirical analysis focuses on the decadal averages between the 1840s and the 1930s of the share of illiterate French army conscripts, that is, 20-year-old men who reported for military service in the département where their father lived and who could neither read nor write. In the 2 SLS regressions reported in Table 9, we find that emigration has a negative effect on the share of illiterate conscripts throughout the period. This effect is significant at the $10 \%$ level in the $1840 \mathrm{~s}$ and $1870 \mathrm{~s}$, and barely insignificant during the $1850 \mathrm{~s}$ ( $\mathrm{p}$-value $=0.12$ ), $1860 \mathrm{~s}(\mathrm{p}$-value $=0.23), 1880 \mathrm{~s}(\mathrm{p}$-value $=0.17)$, and $1890 \mathrm{~s}(\mathrm{p}$-value $=0.27)$. The negative effect of emigration on illiteracy is consistently significant for the generations of conscripts in the 1900s, 1910s, and 1930s, that is, for the 20-year-old men who would have benefited from the adoption of the 1881-1882 laws on free and mandatory schooling until age 13. This pattern suggests that in high-emigration areas throughout the 19th century, and despite their limited means, parents attempted to invest relatively more in the human capital of their children compared to the more affluent, low emigration départements. This tendency toward higher literacy rates becomes more evident after 1881-1882 when schooling becomes free and mandatory until the age of 13 . Below we discuss how this pattern may be attributed to the relatively low returns to agricultural labor compared to the other sectors of the economy.

Since World War II, départements which experienced large emigration waves during the French Revolution have maintained their human capital advantage already apparent at the turn of the 20th century. This can be seen in Panels $A$ and $B$ of Figure D.5, where we plot the coefficients associated with the share of émigrés in 2SLS regressions. In Panel $A$ the dependent variable is the share of men ages 16-24 with only a high-school degree in 1968, 1975, 1982, 1990, 1999 and 2010, whereas in Panel $B$ the dependent variable is the share of men ages 16-24 with a college degree in the respective years. The share of émigrés has a positive and significant effect on the share of males age 16-24 with only a high school degree for 1975, 1982, and 1990. Nevertheless, the share of émigrés has a positive and significant effect on the share of men aged 16-24 with a college degree consistently between 1968 and 2010. These results suggest that since World War II, human capital accumulation has been more intense overall in high-emigration regions; although it seems as though there has been a slow convergence over the last two decades in terms of high school completion rates, the relatively earlier transition to widespread literacy 
in high-émigrés areas has conferred upon them an educational edge reflected in a greater flow of college graduates to this day.

\subsubsection{The Opportunity Cost of Education and Child Labor}

Naturally, to understand why literacy rates differ across regions over time, one needs to tease out the forces that shape the demand and supply of schooling locally. This is not an easy task. However, one element that makes the case of France easier to analyze is the fact that primary schooling became free and mandatory until the age of 13 after the adoption of the 1881-1882 laws. Although this would imply that the supply of schooling over time should become more uniform across regions, we find that high-emigration départements experience systematic under provision of primary schools per school-aged (5-15 years of age) population until WWI. This is shown in Panel $A$ of Table D.18. A similar pattern is found in Panel $B$ where the dependent variable is the total public spending per pupil between 1876 and 1901. Panel $C$ of Table D.18 actually suggests that the limited supply of schooling reflected an overall under provision of public goods in high-emigration départements which also had a less dense transportation network up until at least World War I. Moreover, given the role of the Church in the provision of schooling in France before and after the Revolution (see Appendix A.3 for a discussion), it is worth pointing out that Table D.19 shows that the temperature shocks in the summer of 1792 are not correlated with variables that Franck and Johnson (2016) show to be good proxies for religiosity in France before World War I. This lack of correlation between our instrument and the number of religious communities in each département devoted to education, charity, and solely to religious purposes in 1856 (from the 1856 French census), as well as the share of representatives in the lower house of Parliament who voted against the separation of Church and State in 1905 (Franck (2010)), suggests that the Church's ability to provide education in the 19th century was uncorrelated with emigration during the Revolution.

In light of these observations, the fact that literacy became more widespread in the highemigration regions which received overall fewer public goods (including public primary schools) is all the more striking. But what may rationalize this pattern? We offer two complementary pieces of evidence.

First, a potential explanation for the rise in literacy across high-emigration areas from the late 19th century onward may be partly attributed to the observation that one of the factors that influence human capital investments is the relative return of working in agriculture versus services and industry. To the extent that literacy is arguably more complementary to non agricultural occupations, a larger gap in labor productivity in favor of services and industry might act as a catalyst for human capital accumulation. We already noted in Panel $A$ of Table 5 that the 
emigration wave during the Revolution had a negative impact on labor productivity in all sectors of the economy until World War II. But what happened to the relative sectoral returns? In Panel $C$ of Table 5, we run 2SLS regressions where the dependent variable is the ratio of the value added per worker in the non agricultural sector (i.e., industry and services) vis-à-vis the agricultural one in 1860, 1930, 1982, and 1990. Emigration had a positive and significant effect on this ratio at the $1 \%$ level in 1860 and 1930 in columns (1) and (2), suggesting the relative desirability of the nonagricultural sector of the local economy in high-emigration départements. In columns (3) and (4), the effect of emigration on the relative labor productivities in 1982 and 1990 is insignificant. This would be expected, as a supply response regarding human capital accumulation would eventually lower the differential wages between the agricultural and non agricultural sectors.

A second explanation for the early rise of literacy in the high-emigration areas can be traced to the opportunity cost of acquiring education. Besides the direct monetary cost of attending school, a relevant but often underappreciated part of the decision on whether to acquire schooling would be the forgone wages that a child would bring home. In the case of 19th-century France, this outside option would be tightly linked to productivity in agriculture. ${ }^{28}$ Taking into account both the depressed labor productivity in the agricultural sector of high-émigrés areas until World War II and the decline in the monetary costs of primary schooling after 1881, it is plausible to expect individuals in high-émigrés départements to eventually accumulate human capital at a faster pace instead of working in the agricultural sector.

We examine the conjecture that children and teenagers would be less likely to work in the agricultural sector by using data from the 1929 agricultural survey. This survey provides information at the département level on the number of individuals below the age of 15 working in agriculture. The 2SLS regression results reported in Table 10 show that in high-emigration départements in 1929, individuals below the age of 15 were systematically less likely to work in the agricultural sector, and presumably more likely to stay in school. The pattern is the same whether the baseline is the overall workforce in agriculture, the number of daily agricultural workers, the total number of daily agricultural workers (including foreign workers) below the age of 15, or the total number of French and foreign daily agricultural workers above the age of 15.

In an effort to provide some historical background to the uncovered relationship between returns to agriculture and the relative delay in human capital accumulation in low-emigration areas during the 19th century, we turn to the parliamentary debates which preceded the adoption of mandatory schooling laws in France. In this respect, it is interesting to examine the debates held in 1881-1882 when laws on mandatory schooling until age 13 were first adopted, but also

\footnotetext{
${ }^{28}$ The adverse effect of higher agricultural productivity on human capital accumulation has been recently documented by Shah and Steinberg (2015) in the context of India.
} 
in 1936 when mandatory schooling was extended until the age of $14 .{ }^{29}$ Politicians who voiced concerns regarding the implementation of the mandatory schooling laws in 1881-1882, such as Jean-Edmond Laroche-Joubert who supported them or Ferdinand Boyer who opposed them, thought that parents would refuse to send their children to school because they would be deprived of the wages that their children would earn by working on nearby large farms (Journal Officiel, Debats, Chambre des députés 18-21 décembre 1880, pp. 36-75). ${ }^{30}$ Laroche-Joubert represented in the lower house of Parliament the Charente département, a low-emigration area with a high ratio of large to small farms, while Boyer represented in the lower house of Parliament the Gard département, also a low-emigration place with a median ratio of large to small farms. In 1936, the same type of argument was made by Henri Connevot, who represented Creuse, a lowemigration département with a high ratio of large to small farms in the upper house of Parliament. Specifically, Connevot was in favor of the law but expressed his concerns that "in our rural areas, very often, thirteen-year old children, as soon as they pass the primary school certificate, are sent away to work by their parents, both boys and girls, to earn 100 francs per month the first year and 150 francs per month the second year. These are therefore three thousands francs which are lost by needy families. It will therefore be very difficult to enforce the law, or it will be necessary to grant allowances to those families." (Journal Officiel, Débats Parlementaires, Sénat, 28 juillet 1936, p 903. Translation is ours.)

Emigration, Landownership and Comparative Development Weaving together the evidence so far, one may wonder whether the time-varying impact of émigrés on comparative development may be quantitatively explained by the persistent differences in the composition of agricultural landholdings brought about by the emigration during the Revolution. In other words, can the relative increase in the number of small landowners account for the inverse relationship between emigration rates and agricultural productivity in the medium run, as well as higher human capital accumulation and better economic performance after World War II?

We examine this hypothesis in Table 11 where we assess the change in the magnitudes of our baseline findings regarding the value added per worker in agriculture in 1860 (Table 5) and GDP per capita in 2010 (Table 4) when we account for the ratio of farms above 40 ha to farms below 10 ha in 1862, which reflects the degree of concentration in landownership. First, the association between the ratio of large to small farms and economic performance changes sign

\footnotetext{
${ }^{29}$ In 1881-1882, as well as in 1936, most of the politicians who supported mandatory schooling laws did so because they thought that the development of a state-funded secular system would consolidate the Republican regime by weakening the Catholic Church. Conversely, the opposition to the mandatory schooling laws was motivated by the defense of the Catholic school system (see Franck and Johnson (2016) and the references therein).

${ }^{30}$ Jules Ferry, who was the prime minister when the June 16, 1881, law was adopted and minister of education when the March 28, 1882, law was passed, conceded that the implementation of mandatory schooling might be problematic. (Journal Officiel, Chambre des Députés, 20 décembre 1880, p. 112).
} 
over time, similar to the effect of emigration during the Revolution. A département dominated by large farms in mid-19th-century France was significantly more productive in agriculture in 1862; however, départements where the agricultural sector was populated by small- and medium-sized farmers in 1862 have higher income per capita in 2000. Moreover, accounting for the composition of agricultural holdings decreases the estimated coefficient on the share of émigrés by roughly half when the dependent variable is the value added per worker in agriculture in 1860, and by approximately $40 \%$ when the variable of interest is GDP per capita in 2010 . This implies that a sizeable fraction of the observed reversal in the relationship between emigration rates during the Revolution and subsequent economic performance is indeed driven by the nonmonotonic impact of the concentration in landownership on comparative development.

The uncovered evidence is complementary to the mechanism proposed by Franck and Galor (2015), who argue that the early industrialization across French départements led to underinvestment in education and lower employment in skilled-intensive occupations.

\section{Conclusion}

It is widely debated whether the 1789 Revolution enabled economic growth and industrialization in France or stalled French development by consolidating an agrarian structure of small nearsubsistence farmers. In this study, we focus on the economic consequences of the local weakening of the Old Regime, as proxied by the share of émigrés, mostly aristocrats, wealthy landowners and clergymen, who fled France during the 1789-1799 period and whose property was confiscated and sold by the revolutionaries. Our identification strategy exploits local variation in temperature shocks during the summer of 1792 to obtain plausibly exogenous variation in the share of émigrés across French départements. Emigration intensified in August and September of 1792 when the Revolution took a radical turn. King Louis XVI was imprisoned, and a few weeks later, the first French Republic was proclaimed. At this critical juncture of the French Revolution, we show that local shocks in the economic environment (captured by temperature shocks) are a strong predictor of local emigration rates.

The study establishes that emigration during the French Revolution has had a nonmonotonic impact on regional income per capita over the subsequent 200 years. While emigration had a negative impact on income during the 19th century, it had a positive and significant effect in the long run. We suggest several mechanisms that may rationalize this pattern. First, in départements with more émigrés, there was more land redistribution. Large estates were fragmented into smaller ones. This pattern may explain the archaic means of agricultural production in France and its delayed industrialization during the 19th century. Second, the size and composition of the local elites were shaped by emigration during the Revolution. High-emigration areas had fewer 
wealthy individuals as well as fewer large landowners.

We conjecture that the changes in the economic environment due to emigration during the Revolution shaped the incentives for human capital accumulation over time. Specifically, we find that high-emigration départements have systematically higher literacy rates among the conscripts even before the adoption of the laws regarding free and mandatory schooling in 1881-1882, and this relationship further strengthens with respect to the generations born thereafter.

This early rise in literacy rates may be linked to two elements influencing human capital accumulation. First, départements with a higher share of émigrés in the population during the Revolution are shown to have a larger gap in labor productivity in favor of the industrial and service sectors up until World War II. To the extent that human capital is complementary to non agricultural activities, raising the relative productivity of the latter would incentivize the accumulation of basic literacy in high-emigration areas. Second, the opportunity cost of acquiring education reflected in agricultural productivity was lower in the high-emigration départements. Indeed, using data from 1929, we show that child labor in agriculture was lower in départements with low-emigration rates and high-agricultural productivity, underlying the adverse dynamic impact of high opportunity cost on school attendance. Since World War II, these départements have kept their edge in education, as reflected in higher rates of college graduates today. As such, the reduction in the share of wealthy individuals in the local population and the fragmentation of agricultural property in the wake of the Revolution are consistent with studies predicting a nonmonotonic role of equality in the process of development (Galor and Zeira (1993), Galor and Moav (2004)).

Our study suggests several potential avenues for future research. For example, political upheavals at different stages of development may shape economic trajectories and social preferences across generations, and lead to the emergence of new political institutions over time. Second, our study suggests that radical policies of land redistribution in agrarian societies can have economic consequences that have a time-varying impact. Further research could explore how policies specific to the industrial or service sector may influence the long-term evolution of human capital. 


\section{References}

Acemoglu, D., D. Cantoni, S. Johnson, and J. A. Robinson (2011): "The consequences of radical reform: the French Revolution," American Economic Review, 101(7), 3286-3307.

Acemoglu, D., T. A. Hassan, and J. A. Robinson (2011): "Social structure and development: a legacy of the Holocaust in Russia," Quarterly Journal of Economics, 126(2), 895-946.

Ado, A. (1987 [2012]): Paysans en révolution. Terre, pouvoir et jacquerie, 1789-1794. Société des Etudes Robespierristes, Paris, France.

Aftalion, F. (1990): The French Revolution: an economic interpretation. Cambridge University Press, Cambridge, UK.

Agulhon, M., G. Désert, and R. Specklin (1976): "Apogée et crise de la civilisation paysanne," in Histoire de la France rurale, ed. by G. Duby, and A. Wallon, vol. 3. Editions du Seuil, Paris, France.

Arnaud, G. (1904): Histoire de la révolution dans le département de l'Ariège (1789-1795). Edouard Privat, Toulouse, France.

Baldensperger, F. (1924): Le mouvement des idées dans l'émigration française (1789-1815). Plon-Nourrit, Paris.

Balla, E., and N. D. Johnson (2009): "Fiscal crisis and institutional change in the Ottoman Empire and France," Journal of Economic History, 69(3), 809-845.

Banerjee, A., E. Duflo, G. Postel-Vinay, and T. Watts (2010): "Long-run health impacts of income shocks: wine and phylloxera in nineteenth-century France," Review of Economics and Statistics, 92(4), 714-728.

BArral, J.-A. (1858): Drainage, irrigations, engrais liquides, tome troisième (2e édition). Librairie agricole de la maison rustique, Paris France.

Bastien, P. (2006): L'exécution publique à Paris au XVIIIe siècle. Une histoire des rituels judiciaires. Champ Vallon, Seyssel, France.

BÉe, M. (1983): "Le spectacle de l'éxécution dans la France d'Ancien Régime," Annales, Histoire, Sciences Sociales, 38(4), 843-862.

Biard, M. (1995): Collot d'Herbois: légendes noires et Révolution. Presses Universitaires de Lyon, Lyon, France. 
Blattman, C., and E. Miguel (2010): "Civil War," Journal of Economic Literature, 48(1), $3-57$.

Bloch, M. (1929): "Les plans parcellaires," Annales d'Histoire Economique et Sociale, 1(1-2-3), 60-70,225-231,390-398.

Bluche, F. (1992): Septembre 1792: logiques d'un massacre. Robert Laffont, Paris, France.

Bodinier, B. (1999): "La vente des biens nationaux: essai de synthèse," Annales historiques de la Révolution française, 315(1), 7-19.

Bodinier, B., And E. Teyssier (2000): L'événement le plus important de la révolution, la vente des biens nationaux. Société des études robespierristes et Comité des travaux historiques et scientifiques, Paris, France.

Boisnard, L. (1992): La noblesse dans la tourmente, 1774-1802. Taillandier, Paris, France.

Bonin, S., and C. Langlois (1997): Atlas de la Révolution Française, Vol 10 - Economie. Editions de l'Ecole des Hautes Etudes en Sciences Sociales, Paris, France.

Bonneuil, N. (1997): Transformation of the French Demographic Landscape, 1806-1906. Clarendon Press, Oxford, UK.

Bosker, M., E. Buringh, and J. L. van Zanden (2013): "From Baghdad to London: unravelling Urban Development in Europe and the Arab World 800-1800," Review of Economics and Statistics, 95(4), 1418-1437.

Bouloiseau, M. (1972): La république jacobine, 10 août 1792 - 9 thermidor an II. Le Seuil, Collection Points Histoire, Paris, France.

Bouton, C. A. (1993): The flour war: gender, class and community in late ancien régime. Pennsylvania State University Press, State College, PA.

Brissot, J.-P. (1792): Second discours de J.P. Brissot, député, Sur la nécessité de faire la guerre aux Princes allemands, prononcé a la Société des Amis de la Constitution, séante aux Jacobins, à Paris dans la séance du 30 décembre 1791. De l'Imprimerie du Patriote François, Place du Théâtre Italien, Paris.

Caron, P. (1935): Les massacres de septembre. Maison du livre français, Paris, France.

Carra, J.-L. (1782): Système de la raison: ou le prophète philosophe. Kearby, London, UK. 
Caruana-Galizia, P. (2013): "Estimating French regional income: departmental per capita gross value added, 1872-1911," Research in Economic History, 29, 71-95.

Cassirer, E. (1932 [2009]): The Philosophy of the Enlightenment. Princeton University Press, Princeton, NJ.

Chateaubriand, F.-R. D. (1847): "Opinion sur le projet de loi tendant a indemniser les anciens propriétaires de biens fonds confisqués et vendus au profit de l'Etat, en vertu des lois révolutionnaires, prononcée a la Chambre des Pairs, le 11 avril 1825," in Oeuvres Complètes Tome Deuxième (Oeuvres Politiques). Firmin Didot, Paris, France.

Chevallier, E. (1887): Les salaires au XIXe siècle. Arthur Rousseau, Paris, France.

Coale, A. J. (1969): "The Decline of Fertility in Europe from the French Revolution to World War II," in Fertility and Family Planning : A World View, ed. by S. Behrman, L. Corsa, and R. Freedman, pp. 3-24, Ann Arbor, MI. University of Michigan Press.

Coвb, R. (1972): Reactions to the French Revolution. Oxford University Press, Cambridge, UK.

Cobban, A. (1962): The social interpretation of the French Revolution. Cambridge University Press, Cambridge, UK.

Combes, P.-P., M. Lafourcade, J.-F. Thisse, and J.-C. Toutain (2011): "The rise and fall of spatial inequalities in France: a long-run perspective," Explorations in Economic History, $48,243-271$.

Conley, T. G. (1999): "GMM Estimation with Cross Sectional Dependence," Journal of Econometrics, 92(1), 1-45.

Crépin, A. (2009): Histoire de la conscription. Gallimard, Folio Histoire, Paris.

Crouzet, F. (1964): "Wars, blockade, and economic change in Europe, 1792-1815," Journal of Economic History, 24(4), 567-588.

(2003): "The historiography of French economic growth in the nineteenth century," Economic History Review, 56(2), 215-242.

Darnton, R. (1973): "The Encyclopédie wars of prerevolutionary France," American Historical Review, 78(5), 1331-1352.

Daudin, G. (2010): "Domestic trade and market size in late eighteenth-century France," Journal of Economic History, 70(3), 716-743. 
DAvid, P. A. (1975): Technical choice innovation and economic growth. Essays on American and British experience in the 19th century. Cambridge University Press, New York, NY.

Dell, M. (2012): "Path Dependence in Development: Evidence from the Mexican Revolution," mimeo, Harvard University, Department of Economics.

DU Motey, H. R. (1893): Une paroisse rurale au duché d'Alençon: Saint-Germain-de Clairefeuille, des origines de la paroisse à 1790. E. Renaut-deBroise, Alençon, France.

Duc de Castries, R. (1966): La vie quotidienne des émigrés. Hachette, Paris, France.

Dupâquier, J., And M. DupÂquier (1985): Histoire de la démographie. Perrin, Paris, France.

Finley, T., R. Franck, and N. D. Johnson (2017): "The effects of land redistribution: evidence from the French Revolution," Working paper, George Mason University.

Fiszbein, M. (2016): "Agricultural diversity, structural change and long-run development: evidence from US counties," Working paper, Boston University.

France - Ministère de la Guerre (1839-1937): Compte rendu sur le recrutement de l'armée. Imprimerie Nationale, Paris.

FRANCK, R. (2010): "Economic growth and the separation of Church and State: the French case," Economic Inquiry, 48(4), 841-859.

(2016): "The political consequences of income shocks: explaining the consolidation of democracy in France," Review of Economics and Statistics, 98(1), 57-83.

Franck, R., And O. Galor (2015): "Is Industrialization Conducive to Long-Run Prosperity?," CESifo Working Paper Series No. 5354.

(2017): "Technology-Skill Complementarity in Early Phases of Industrialization," National Bureau of Economic Research Paper No. 23197.

Franck, R., And N. D. Johnson (2016): "Can public policies lower religiosity? Evidence from school choice in France, 1878-1902," Economic History Review, 69(3), 915-944.

Franck, R., N. D. Johnson, and J. V. C. Nye (2014): "From internal taxes to national regulation: evidence from a French wine tax reform at the turn of the twentieth century," Explorations in Economic History, 51(1), 77-93.

Furet, F. (1978): Penser la révolution française. Gallimard, Paris, France. 
Furet, F., And J. Ozouf (1977): Lire et écrire. L'alphabétisation des français de Calvin à Jules Ferry. Editions de Minuit, Paris, France.

Furet, F., And M. Ozouf (1988): Dictionnaire critique de la Révolution française. Flammarion, Paris, France.

Galor, O., And O. Moav (2004): "From physical to human capital accumulation: inequality and the process of development," Review of Economic Studies, 71(4), 1001-1026.

Galor, O., And J. Zeira (1993): "Income Distribution and Macroeconomics," Review of Economic Studies, 60(1), 35-52.

Garrioch, D. (2002): The making of revolutionary Paris. University of California Press, Berkeley, Berkeley, CA.

GAY, P. (1966): The Enlightenment: an interpretation; the rise of modern paganism. Alfred Knopf, New York, NY.

(1969): The Enlightenment: an interpretation; the science of freedom. Alfred Knopf, New York, NY.

Godechot, J. (1951): Les institutions de la France sous la Révolution et l'Empire. Presses Universitaires de France, Paris, France.

Greer, D. (1935): The incidence of the terror during the French Revolution: a statistical interpretation. Gloucester, MA: P. Smith.

(1951): The incidence of the emigration during the French Revolution. Gloucester, MA: P. Smith.

GRIGG, D. B. (1992): The transformation of agriculture in the West. Blackwell, Oxford, UK.

Grosfeld, I., S. O. Sakalli, and E. Zhuravskaya (2017): "Middleman minorities and ethnic violence: anti-Jewish pogroms in the Russian empire," Paris School of Economics Working Paper, 0(0), 00-00.

Gueniffey, P. (2011): "La grande terreur: naissance et mort d'une idéologie," in Histoires de la révolution et de l'empire, pp. 237-302. Perrin, Paris.

Guizot, F. (1829-1832): Histoire générale de la civilisation en Europe depuis la chute de l'empire romain jusqu'à la révolution française. Pichon et Didier, Paris, France. 
Haun, J. (1973): "Visual quantification of wheat development," Agronomy Journal, 65(1), 116119.

Havard, O. (1911-1913): Histoire de la révolution dans les ports de guerre. Toulon. Nouvelle Librairie Nationale, Paris, France.

Heckscher, E. F. (1922): The continental system: an economic interpretation. Clarendon Press, Oxford, UK.

Heller, H. (2006): The Bourgeois Revolution in France, 1789-1815. Bergham Books, New York, NY.

Henderson, W. (1957): "The Anglo-French commercial treaty of 1786," Economic History Review, 10(1), 104-112.

Hidalgo, F. D., S. Naidu, S. Nichter, and N. Richardson (2010): "Economic Determinants of Land Invasions," Review of Economics and Statistics, 92(3), 505-523.

Higonnet, P. L.-R. (1981): Class, ideology, and the rights of nobles during the French

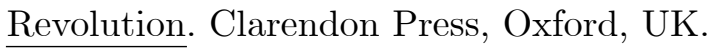

Hobsbawm, E. J. (1990): Echoes of the Marseillaise: two centuries look back on the French

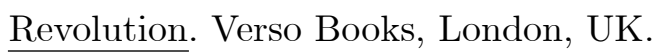

Hoffman, P. T., G. Postel-Vinay, and J.-L. Rosenthal (2000): Priceless Markets. The Political Economy of Credit in Paris, 1660-1870. University of Chicago Press, Chicago, IL.

Hyslop, B. F. (1934): French nationalism in 1789 according to the General Cahiers. Columbia University Press, New York, NY.

IsRAeL, J. (2014): Revolutionary ideas: an intellectual history of the French Revolution from the rights of man to Robespierre. Princeton University Press, Princeton,NJ.

JAuRÈs, J. (1901-1903): Histoire socialiste de la Révolution française, Edition revue par A. Mathiez (1922-1924). Editions de la Librarie de l'Humanité, Paris.

Johnson, H. C. (1986): The Midi in revolution. Princeton University Press, Princeton, NJ.

Jones, C. (2002): The Great Nation : France from Louis XV to Napoleon 1715-1799. Penguin Press, London, UK.

Jones, P. (1988): The peasantry in the French Revolution. Cambridge University Press, Cambridge, UK. 
JuHÁsz, R. (2015): "Temporary protection and technology adoption: evidence from the Napoleonic blockade," Working Paper.

Kaplan, S. L. (1984): Provisioning Paris - merchants and millers in the grain and flour trade during the eighteenth century. Cornell University Press, Ithaca, NY.

(1996): The bakers of Paris and the bread question 1700-1775. Duke University Press, Durham, NC.

Koyré, A. (1948): “Condorcet," Journal of the History of Ideas, 9(2), 131-152.

Labrousse, E. (1933): Esquisse du mouvement des prix et des revenus en France au XVIIIe siècle. Librairie Dalloz, Paris, France.

Labrousse, E., R. Romano, and F. Dreyfus (1970): Le prix du froment en France au temps de la monnaie stable (1726-1913). Ecole Pratique des Hautes Etudes - SEVPEN, Paris, France.

Lebrun, F., J. Quéniart, and M. Venard (2003): Histoire générale de l'enseignement et de l'éducation en France: de Gutempberg aux Lumières (1480-1789). Perrin - Collection Tempus, Paris, France.

Lecarpentier, G. (1908): La vente des biens écclésiastiques pendant la révolution française. Alcan, Paris.

Lefebvre, G. (1924): Les paysans du Nord pendant la révolution française. C. Robbe, Lille, France.

- (1962): The French revolution, vol. I: from its origins to 1793. Columbia University Press, New York, NY.

Loutchisky, I. (1897): La petite propriété en France et la vente des biens nationaux. Honoré Champion, Paris.

Luterbacher, J., D. Dietrich, E. Xoplaki, M. Grosjean, and H. Wanner (2004): "European Seasonal and Annual Temperature Variability, Trends, and Extremes Since 1500," Science, 303(5663), 1499-1503.

- (2006): "European Seasonal Temperature Reconstructions," IGBP PAGES/World Data Center for Paleoclimatology Data Contribution Series No. 2006-060, NOAA/NCDC Paleoclimatology Program.

Maddison, A. (2001): The World Economy: A Millennial Perspective. Development Centre Studies, OECD. 
Marion, M. (1908): La vente des biens nationaux pendant la révolution (avec étude spéciale des ventes dans les départements de la Gironde et du Cher). Honoré Champion, Paris, France.

Markoff, J. (1996): The abolition of feudalism: peasants, lords, and legislators in the French revolution. Pennsylvania State University Press, Pittsburgh, PA.

Martin, J.-C. (1987): La Vendée et la France, 1789-1799. Editions du Seuil, Paris, France.

(2006): Violence et révolution. Essai sur la naissance d'un mythe national. Editions du Seuil, Paris, France.

Marx, K. (1843 [1970]): Critique of Hegel's Philosophy of Right. Cambridge University Press, Ed. Joseph O’Malley, London.

Mathiez, A. (1922-1924): La Révolution française. Librairie Armand Colin, Paris, France.

Mayeur, F. (2003): Histoire générale de l'enseignement et de l'éducation en France: De la

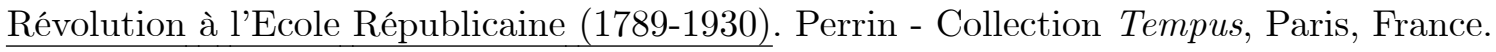

MazA, S. (2003): The myth of the French bourgeoisie: an essay on social imaginary, 1750-1850. Harvard University Press, Cambridge, MA.

McPhee, P. (1999): Revolution and Environment in Southern France Peasants, Lords, and Murder in the Corbières 1780-1830. Oxford University Press, Oxford, UK.

Mornet, D. (1933): Les origines intellectuelles de la révolution française. Librarie Armand Colin, Paris, France.

Nassiet, M. (1993): Noblesse et pauvreté. La petite noblesse en Bretagne, XVe-XVIIIe siècle. Presses Universitaires de Rennes, Rennes, France.

Nunn, N. (2008): “The Long Term Effects of Africa's Slave Trades," Quarterly Journal of Economics, 123(1), 139-176.

Nunn, N., And L. Wantchekon (2011): "The Slave Trade and the Origins of Mistrust in Africa," American Economic Review, 101(7), 3221-3252.

Palmer, R. R. (1941): Twelve who ruled: the year of the Terror in the French Revolution. Princeton University Press, Princeton, NJ.

Pauling, A., J. Luterbacher, C. Casty, and H. Wanner (2006): "Five hundred years of gridded high-resolution precipitation reconstructions over Europe and the connection to large-scale circulation," Climate Dynamics, 26, 387-405. 
Persson, K. G. (1999): Grain markets in Europe 1500-1900. Cambridge University Press, Cambridge, UK.

Peyrard, C. (1996): Les Jacobins de l'Ouest. Sociabilité révolutionnaire et formes de politisation dans le Maine et la Basse Normandie (1789-1799). Publications de la Sorbonne, Paris, France.

RESNiCK, D. P. (1966): The white terror and the political reaction after Waterloo. Harvard University Press, Cambridge, MA.

Rosenthal, J.-L. (1988): The fruits of revolution. Property rights, litigation and French agriculture, 1700-1860. Cambridge University Press, Cambridge, UK.

Sargent, T. J., And F. R. Velde (1995): "Macroeconomic policies of the French Revolution," Journal of Political Economy, 103(3), 474-518.

Schama, S. (1989): Citizens: a chronicle of the French Revolution. Random House, New York, NY.

Scoville, W. C. (1953): "The Hugenots in the French economy," Quarterly Journal of Economics, 67(3), 423-444.

Shah, M., and B. M. Steinberg (2015): "Workforce and human capital investment: evidence from India," NBER Working Paper, 0(21543), 00-00.

Shapiro, G., AND J. MARKOFF (1998): Revolutionary demands: a content analysis of the Cahiers de Doléances of 1789. Stanford University Press, Stanford, CA.

Shaw-TAYlor, L. (2005): "Family farms and capitalist farms in mid nineteenth-century England," Agricultural History Review, 53(2), 158-191.

Soboul, A. (1958): Les sans-culottes parisiens en l'an II: mouvement populaire et gouvernement révolutionnaire, 2 juin 1793 - 9 Thermidor An II. Librairie Clavreuil, Paris, France.

- (1962): Histoire de la Révolution française. Editions Sociales, Paris.

(1968): "Survivances" féodales" dans la société rurale française au XIXe siècle," in Annales. Histoire, Sciences Sociales, vol. 23, pp. 965-986. JSTOR.

Squicciarini, M. P., and N. Voigtländer (2015): "Human capital and industrialization: evidence from the age of enlightenment," Quarterly Journal of Economics, 130(4), 1-40. 
Sutherland, D. (2003): The French Revolution and empire: the quest for a civic order. Blackwell Publishers, Oxford, UK.

TACKett, T. (1986): Religion, revolution, and regional culture in eighteenth-century France: the ecclesiastical oath of 1791. Princeton University Press, Princeton, NJ.

- (2015): The coming of the terror in the French revolution. Harvard University Press, Cambridge, MA.

Taine, H. (1876-1893): Les origines de la France contemporaine. Robert Laffont - Bouquins [2011], Paris, France.

TAYlor, G. V. (1967): "Noncapitalist wealth and the origins of the French Rrevolution," American Historical Review, 72,(2), 469-496.

Thiers, A. (1823-1827): Histoire de la révolution française. Lecointre et Durey, Paris, France.

Tilly, C. (1964): The Vendée: a sociological analysis of the counter-revolution of 1793. Harvard University Press, Cambridge, MA.

Tocqueville, A. D. (1856): L’ancien régime et la révolution. Michel Levy, Paris, France.

Toutain, J.-C. (1987): "Le produit intérieur brut de la France de 1789 à 1982," Economies et Sociétés, 21(5), 1-237.

Vivier, N. (1998): Propriété collective et identité communale: les biens communaux en France, 1750-1914. Publications de la Sorbonne, Paris, France.

Vovelle, M. (1985): La mentalité révolutionnaire. Sociétés et mentalités sous la révolution française. Messidor, Paris, France.

Waldinger, M. (2014): "Drought and the French Revolution: the effect of adverse weather conditions on peasant revolts in 1789," Working paper, London School of Economics.

Zadoks, J., T. Chang, and C. KonzaK (1974): "A decimal code for the growth stages of cereals," Weed Research, 14(6), 415-421. 


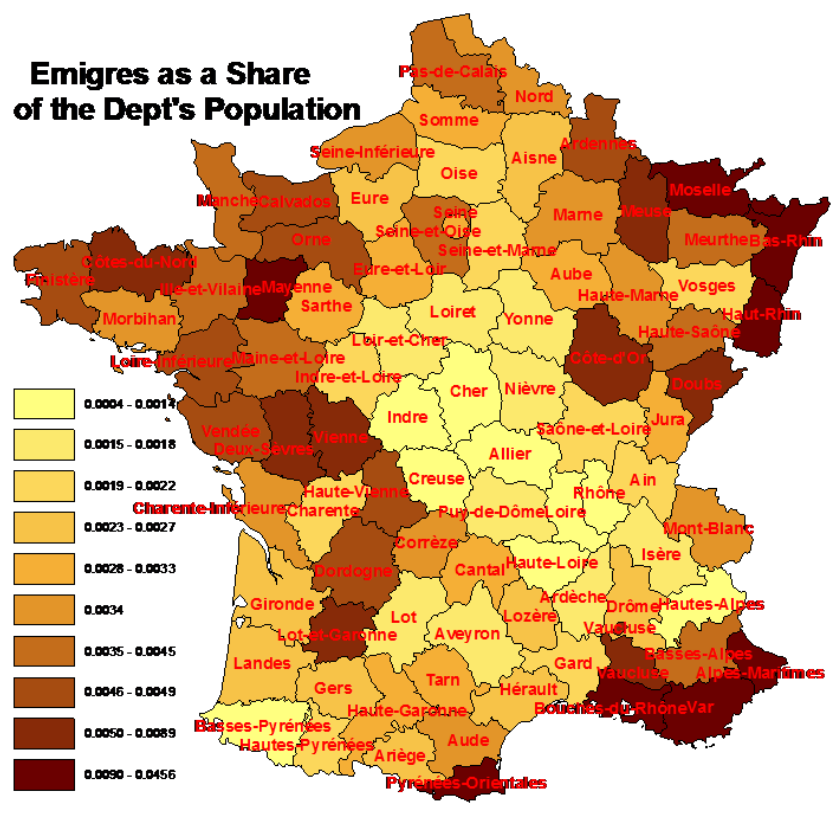

A. Emigrés as a Share of the

Département's Population

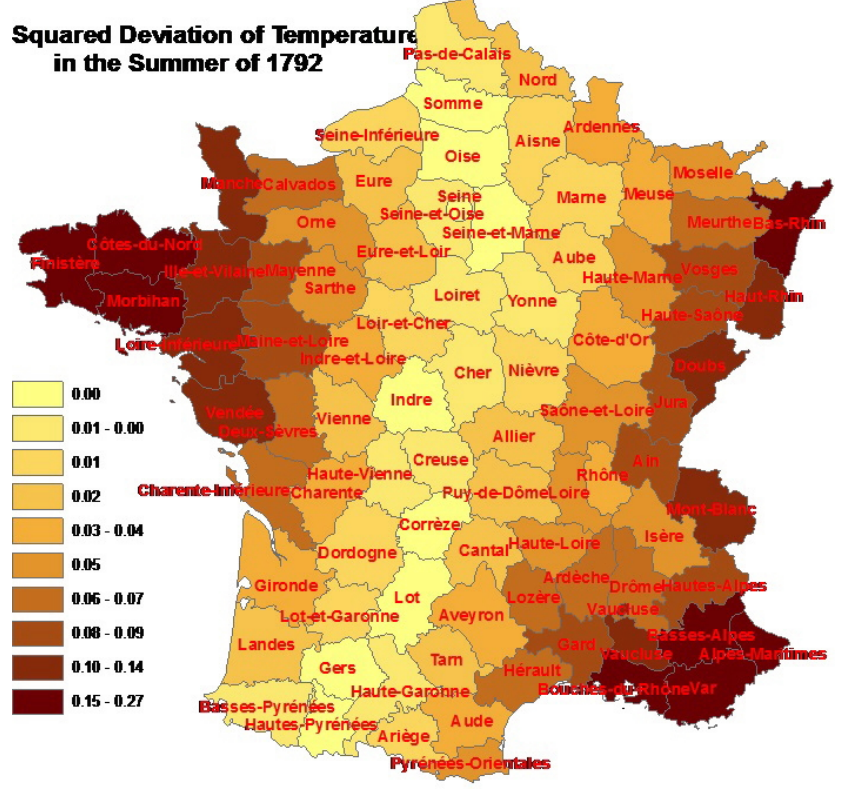

C. Squared Deviation from Temperature

in Summer 1792 (baseline 1767-1791)

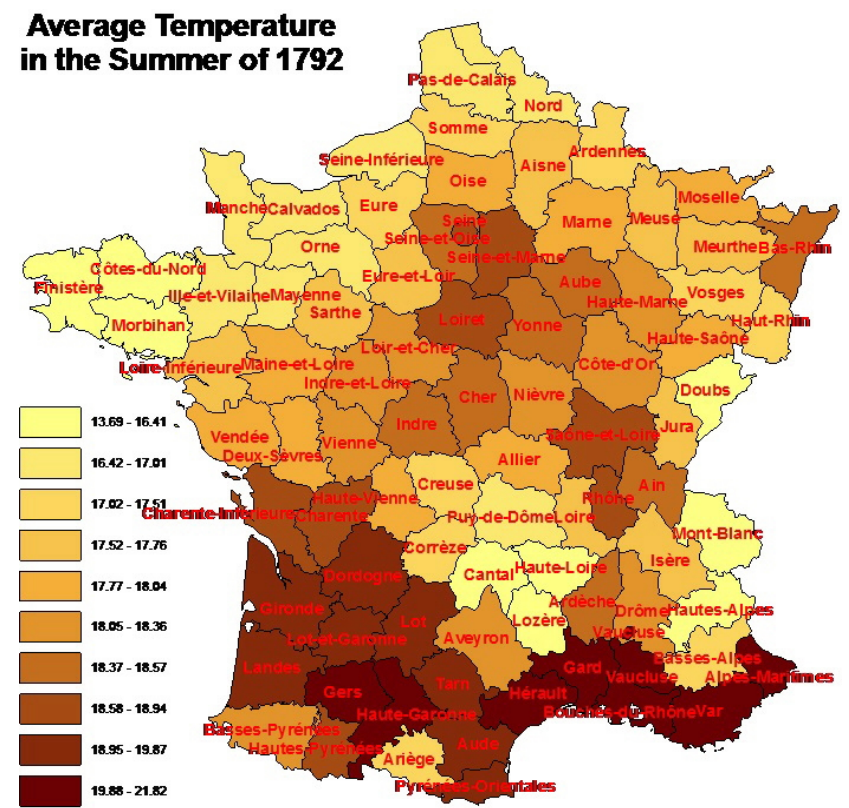

B. Average Temperature in

Summer 1792

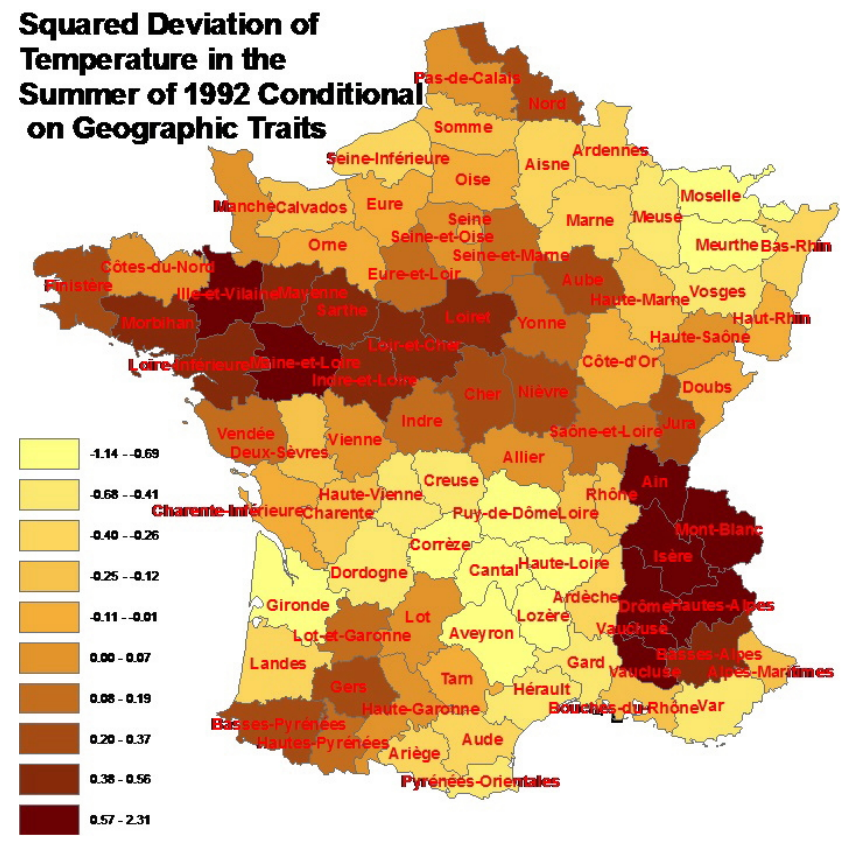

D. Squared Deviation from Temperature

in Summer 1792 (baseline 1767-1791)

Partialing Out Geographic Controls

Figure 1: Share of Emigrés in Population and Summer Temperature in 1792 in French Départements

Source: Greer (1951),Luterbacher, Dietrich, Xoplaki, Grosjean, and Wanner (2004),Luterbacher, Dietrich, Xoplaki, Grosjean, and Wanner (2006); Pauling, Luterbacher, Casty, and Wanner (2006). 


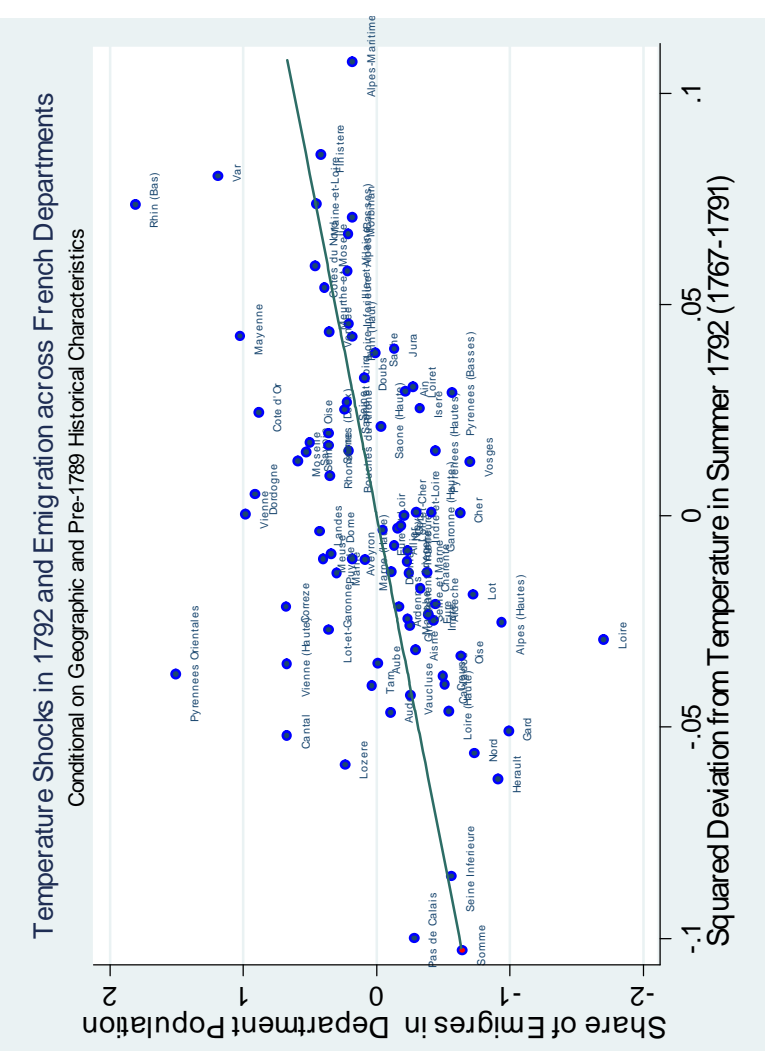

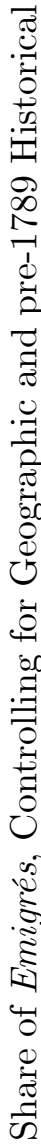
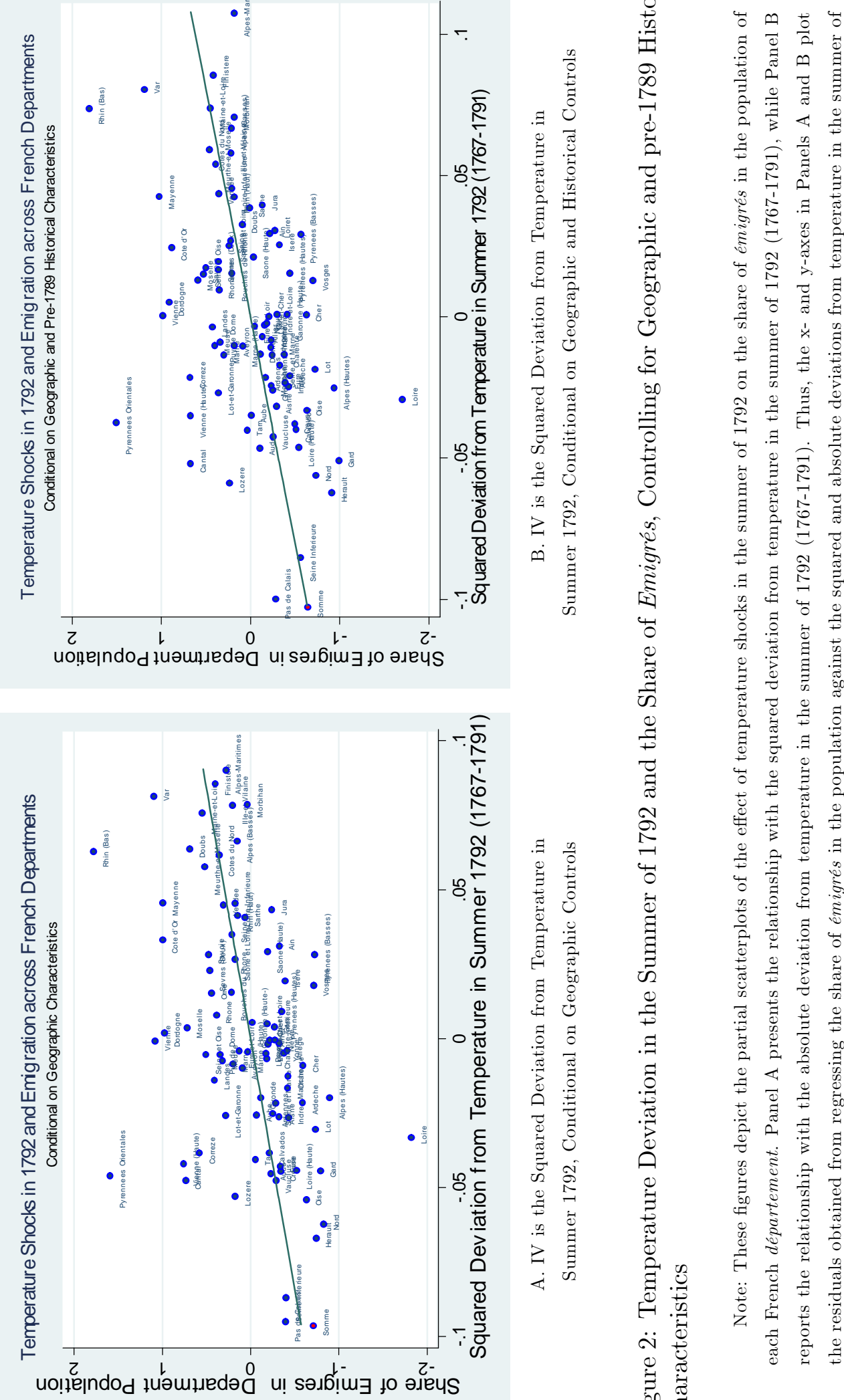

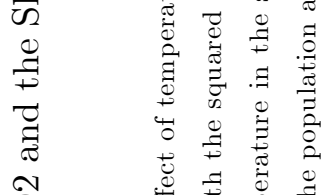

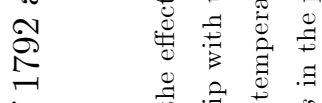

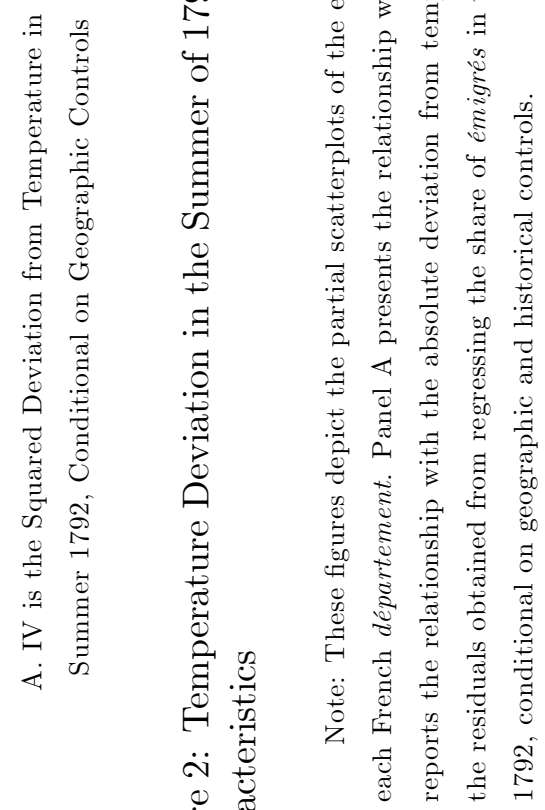




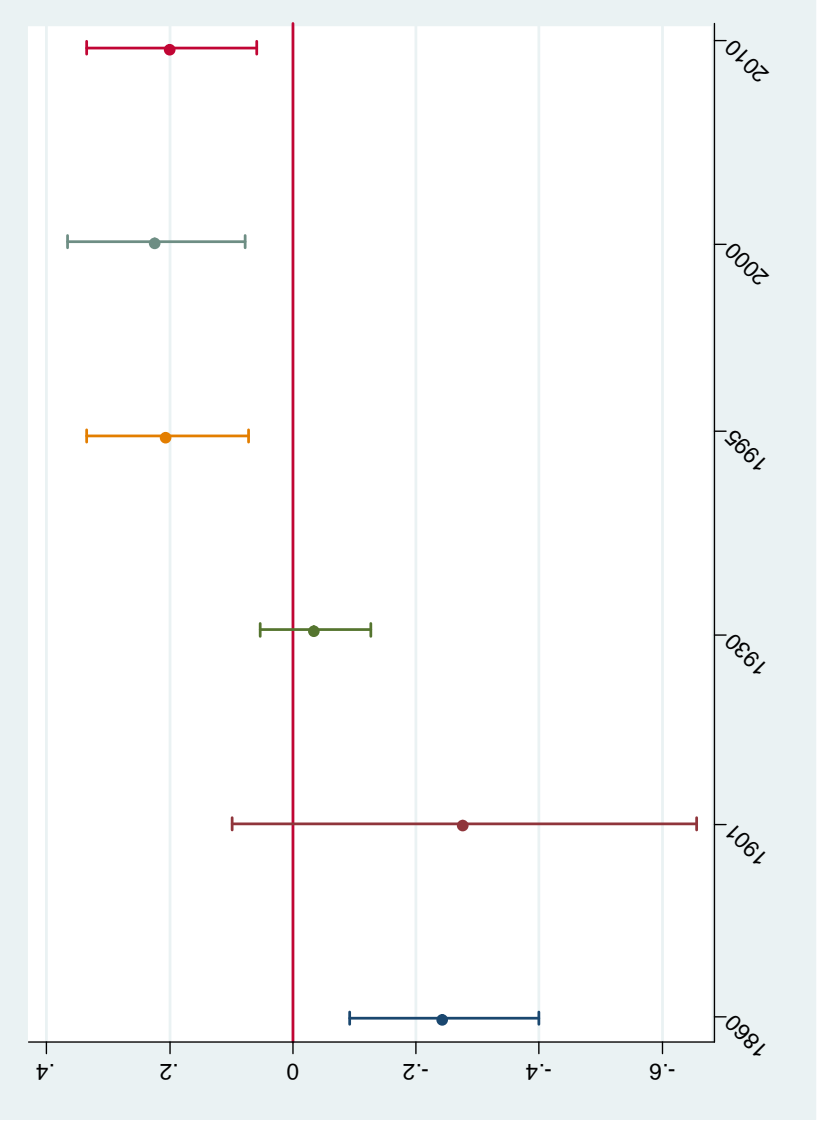

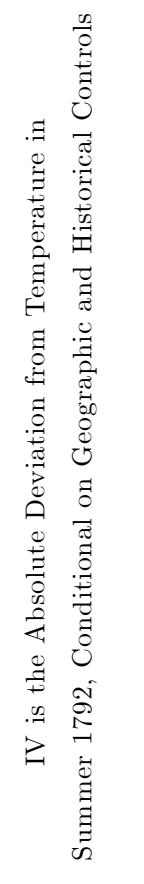

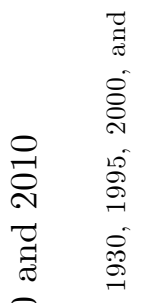

总

is 8

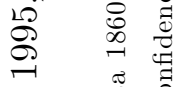

官 营

-1 .

ङे مै

용

$\mathscr{D}_{-1} \quad$.

.$\exists \quad$

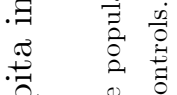

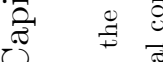

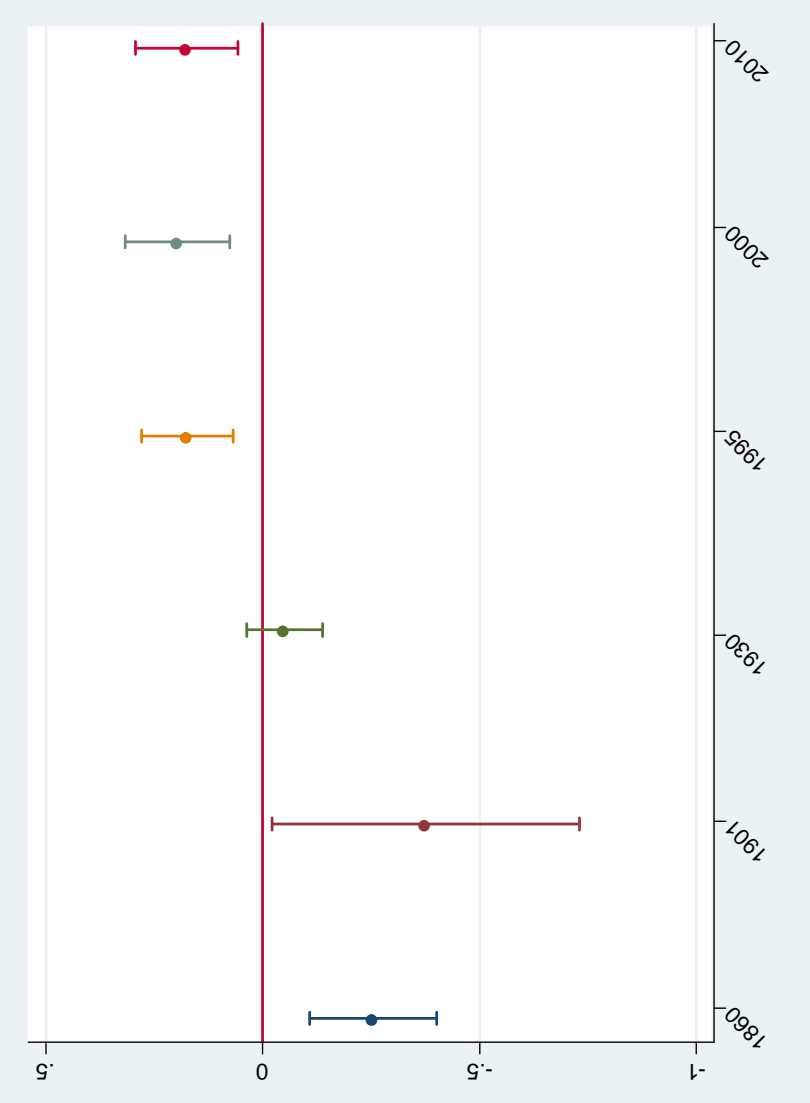

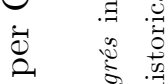

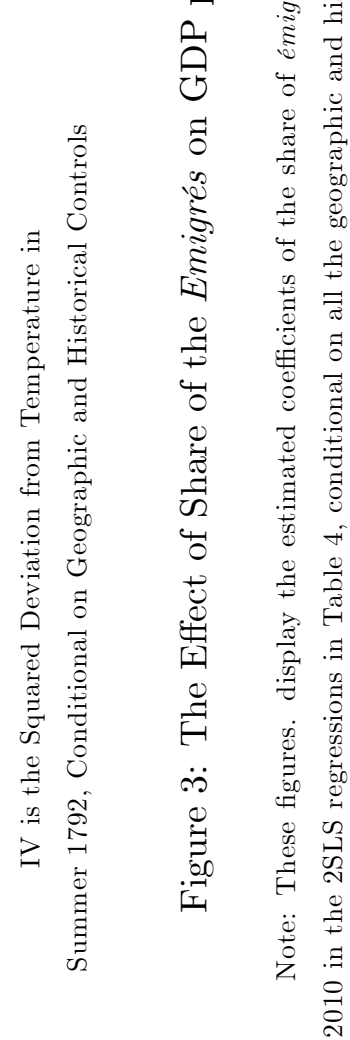



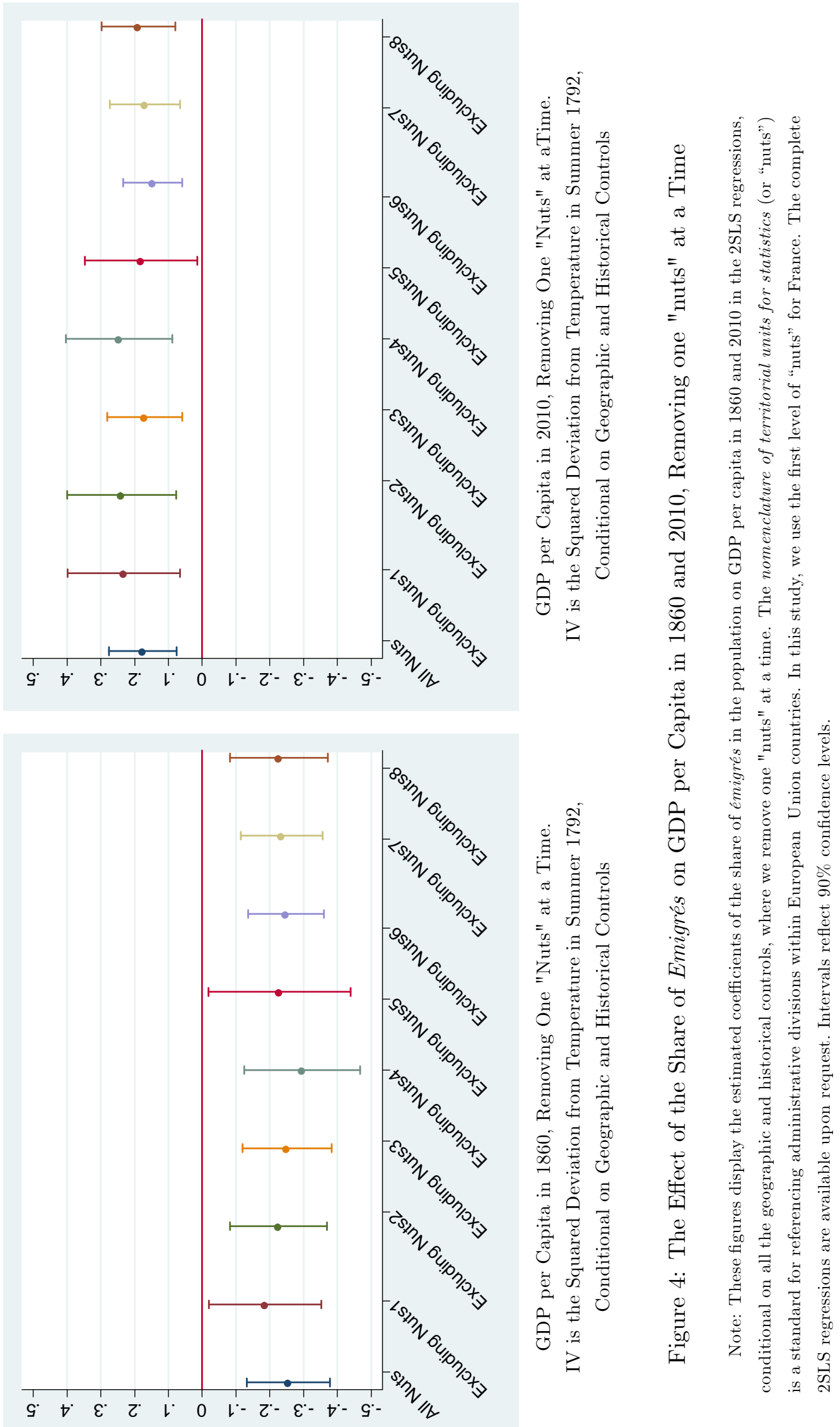


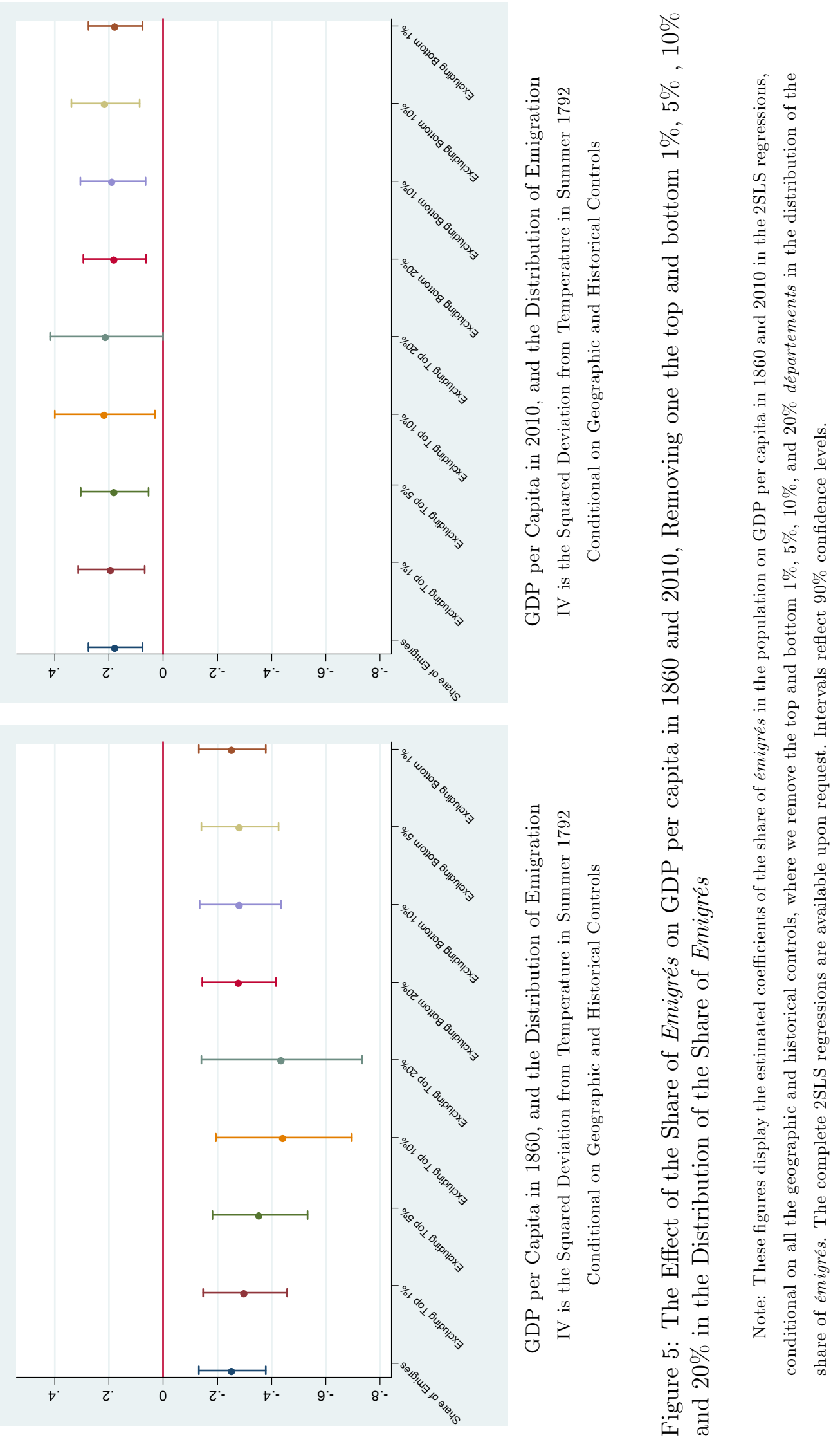




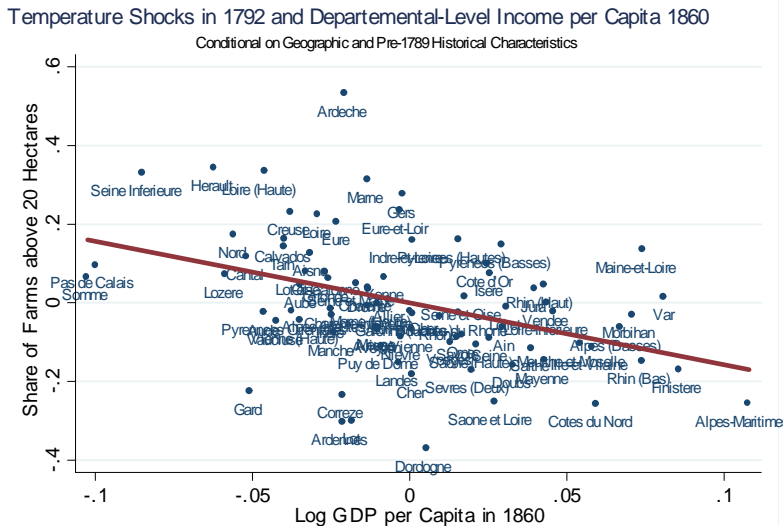

A. IV is the Squared Deviation from

Temperature in Summer 1792

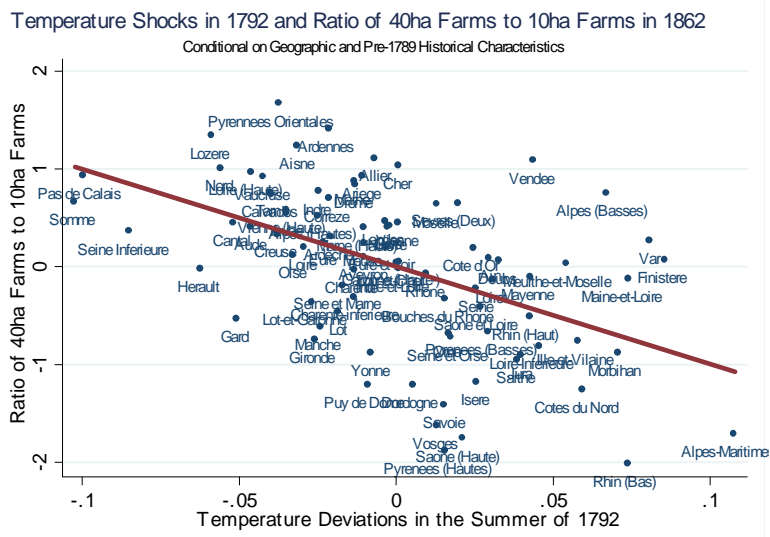

C. IV is the Squared Deviation from

Temperature in Summer 1792

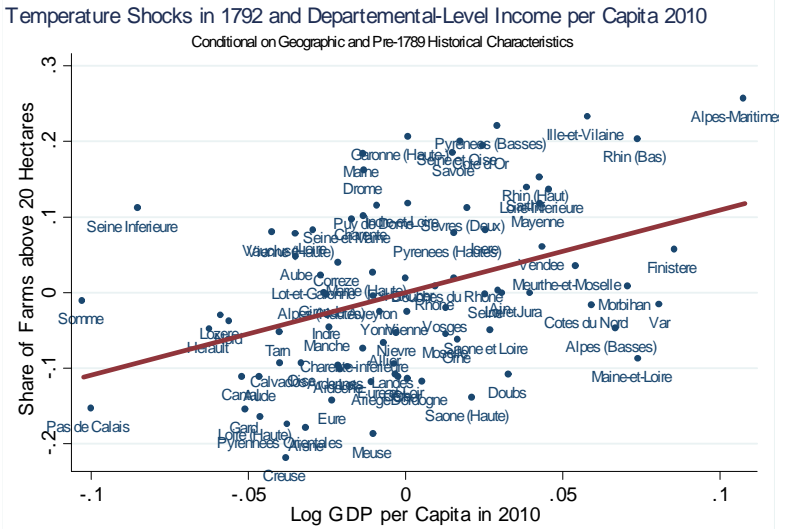

B. IV is the Squared Deviation from

Temperature in Summer 1792

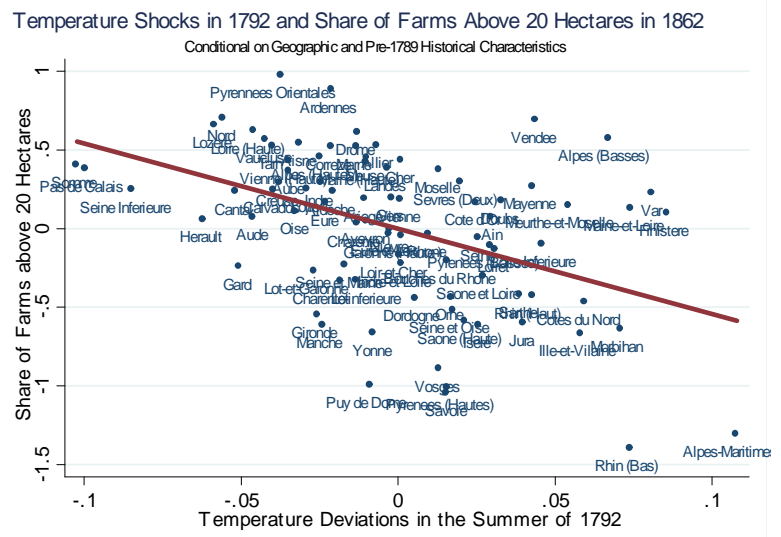

D. IV is the Squared Deviation from

Temperature in Summer 1792

Figure 6: Temperature Deviation in the Summer of 1792 and GDP per Capita in 1860 and 2010, Controlling for Geographic Traits

Note: These figures depict the partial scatterplots of the association between the squared deviation of temperature in the summer of $1792(1767-1791)$ on GDP per capita in 1860 (Panel A), GDP per capita in 2010 (Panel B), the ratio of farms above 40 ha to farms below 10 ha in 1862 (Panel C), as well as the ratio of farms above 20 ha in 1862 (Panel D). Thus, the $\mathrm{x}$ - and y-axes plot the residuals obtained from regressing the share of émigrés in the population against the squared deviations from temperature in the summer of 1792 , conditional on the geographic and historical set of covariates. 
Table 1: Emigrés during the Revolution

\section{Panel A. Départements with High and Low Emigration}

Five départements with largest

\begin{tabular}{|c|c|c|c|c|c|c|c|}
\hline \multicolumn{2}{|c|}{ Number of émigrés } & \multicolumn{2}{|c|}{ Share of émigrés } & \multicolumn{2}{|c|}{ Number of émigrés } & \multicolumn{2}{|c|}{ Share of émigrés } \\
\hline & 3827 & & & & 105 & Loire & \\
\hline Py & 38 & Bouches-du-Rhone & & Hautes-Alpes & 105 & Hautes-Alpes & \\
\hline Bouches-du-1 & 5125 & Var & & Cher & 239 & Cher & $0.11 \%$ \\
\hline Var & 5331 & yrenees Orientales & 3.48 & Haute-Loire & 271 & Rhone & $0.11 \%$ \\
\hline Bas-Rhin & 20510 & Bas-Rhin & $4.56 \%$ & Indre & 278 & Haute-Loire & $0.12 \%$ \\
\hline
\end{tabular}

\section{Panel B. Social Groups}

\begin{tabular}{lccc}
\hline \hline & & & \\
Nobles & $23 \%$ & Priests & $34 \%$ \\
Upper Middle Class & $10 \%$ & Lower Middle Class & $3 \%$ \\
Working Class & $6 \%$ & Peasants & $7 \%$ \\
Unidentified & $17 \%$ & & \\
\hline
\end{tabular}

Panel C. Correlations between Social Groups

\begin{tabular}{|c|c|c|c|c|c|}
\hline & Priests & Nobles & Upper Middle Class & Lower Middle Class & Working Class \\
\hline Nobles & 0.62 & & & & \\
\hline Upper Middle Class & 0.46 & 0.56 & & & \\
\hline Lower Middle Class & 0.54 & 0.50 & 0.80 & & \\
\hline Working Class & 0.58 & 0.52 & 0.71 & 0.89 & \\
\hline Peasants & 0.53 & 0.35 & 0.43 & 0.76 & 0.86 \\
\hline
\end{tabular}

Note: The data on the social categories of émigrés reported in Panels B and $\mathrm{C}$ are only available for 69 out of the 86 départements in mainland France. In Panel C, the correlations are between the natural logarithm of the variables.

Source: Greer (1951). 
Table 2: Property Ownership before and after the French Revolution in 15 Villages in the District of Avesnes in the Nord Département

\begin{tabular}{lcc}
\hline \hline & \multicolumn{2}{c}{ Ownership } \\
& Before & After \\
& the Revolution (\%) \\
\hline & 33.52 & 44.18 \\
Peasants & 4.73 & 25.68 \\
Bourgeois & 37.08 & 14.35 \\
Nobility & 18.80 & 0.03 \\
Church & 0.69 & 0.58 \\
Poor Institutions and Hospitals & 5.18 & 15.80 \\
Commons*
\end{tabular}

Note: * Before the Revolution, there was no clear ownership of the commons.

Source: Lefebvre (1924, Tableau II, pp.892-893).

Table 3: First-Stage Regressions: Squared and Absolute Deviations from Temperature in Summer 1792

$\begin{array}{lllllll}(1) & (2) & (3) & (4) & (5) & (6)\end{array}$

First stage: the instrumented variable is the Share of Emigres

\begin{tabular}{|c|c|c|c|c|c|c|}
\hline Squared Devation from Temperature in Summer 1792 (1767-1791) & $4.450^{* * *}$ & $5.929^{* * *}$ & $6.159^{* * *}$ & & & \\
\hline Absolute Devation from Temperature in Summer 1792 (1767-1791) & & & & $\begin{array}{c}2.365^{* * *} \\
{[0.497]}\end{array}$ & $\begin{array}{c}2.612^{* * *} \\
{[0.708]}\end{array}$ & $\begin{array}{c}2.590^{* * *} \\
{[0.770]}\end{array}$ \\
\hline Geographic Controls & No & Yes & Yes & No & Yes & Yes \\
\hline Historical Controls & No & No & Yes & No & No & Yes \\
\hline F-stat (1st stage) & 17.89 & 18.11 & 16.88 & 22.61 & 13.62 & 11.32 \\
\hline Observations & 85 & 85 & 85 & 85 & 85 & 85 \\
\hline
\end{tabular}

Note: This table reports the first stage of the 2SLS regressions where the IV is the squared deviation of standardized summer temperature in 1792 (columns (1)-(3)) or the absolute deviation of standardized summer temperature in 1792 (columns (4)-(6)) and where the instrumented variable is the share of émigrés in the population (the dependent variable in the second stage of the 2SLS regression is GDP per capita in 1860 as shown in Tables 4 and D.12). The specifications in columns (1) and (4) do not include controls, those in columns (2) and (5) only include geographic controls, while those in columns (3) and (6) include all controls. The dependent variable is in logarithm. Robust standard errors are reported in brackets. *** significant at the $1 \%$ level, ** at the $5 \%$ level, * at the $10 \%$ level. 
Table 4: Emigrés on GDP per Capita (IV: Squared Deviation of Temperature in Summer 1792)

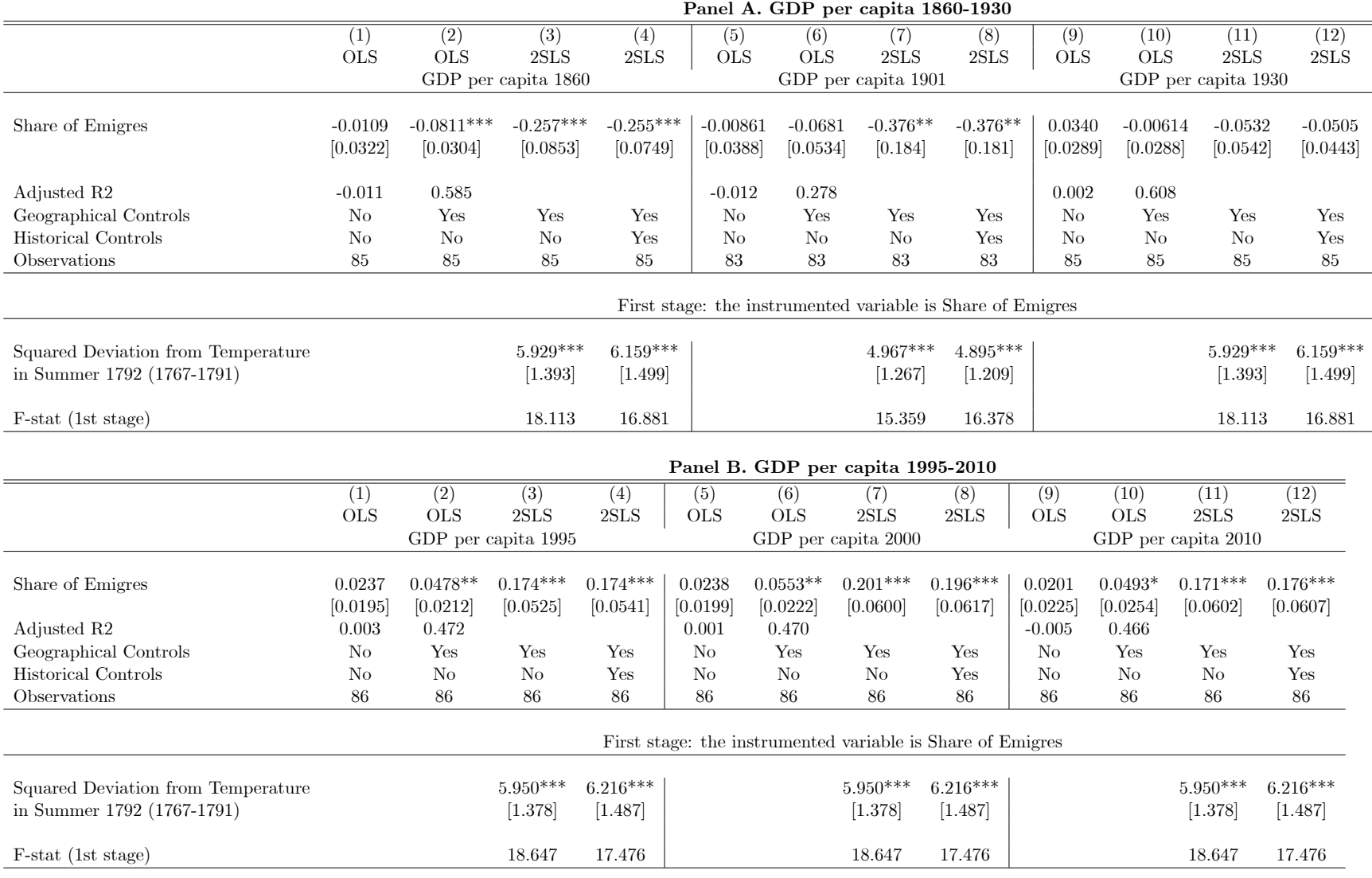

Note: This table reports the effect of the share of émigrés in the population on GDP per capita in 1860, 1901, and 1930 (Panel A) and in 1995, 2000, and 2010 (Panel B) in OLS and 2SLS regressions. All the dependent variables are in logarithm. The IV in the first stage of the 2SLS regressions is the squared standardized deviation from temperature in the summer of 1792. Robust standard errors are reported in brackets. *** significant at the $1 \%$ level, $* *$ at the $5 \%$ level, $*$ at the $10 \%$ level. 
Table 5: The Effect of Emigrés on the Value Added Per Capita and the Workforce in Agriculture, Industry and Services, 1860-1990

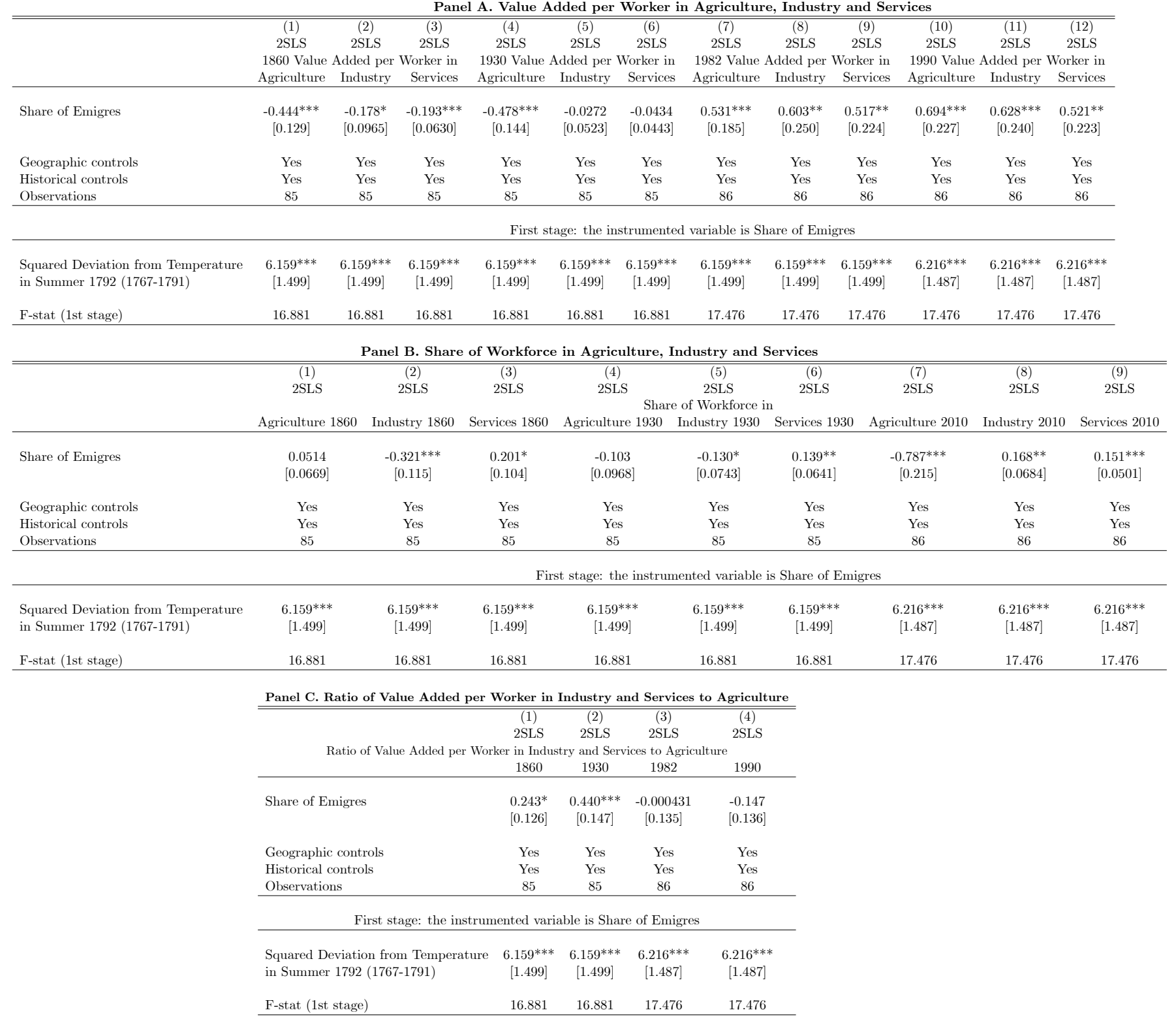

Note: This table reports the effect of the share of émigrés in the population on the value added per worker in agriculture, industry, and services in 1860, 1930, and 1990 (Panel A) and the shares of the workforce in agriculture, industry, and services in 1860, 1930, and 2010 (Panel B) in 2SLS regressions. All the dependent variables are in logarithm. The IV in the first stage of the 2SLS regressions is the squared standardized deviation from temperature in summer 1792. Robust standard errors are reported in brackets. ${ }^{* * *}$ significant at the $1 \%$ level, ${ }^{* *}$ at the $5 \%$ level, ${ }^{*}$ at the $10 \%$ level. 


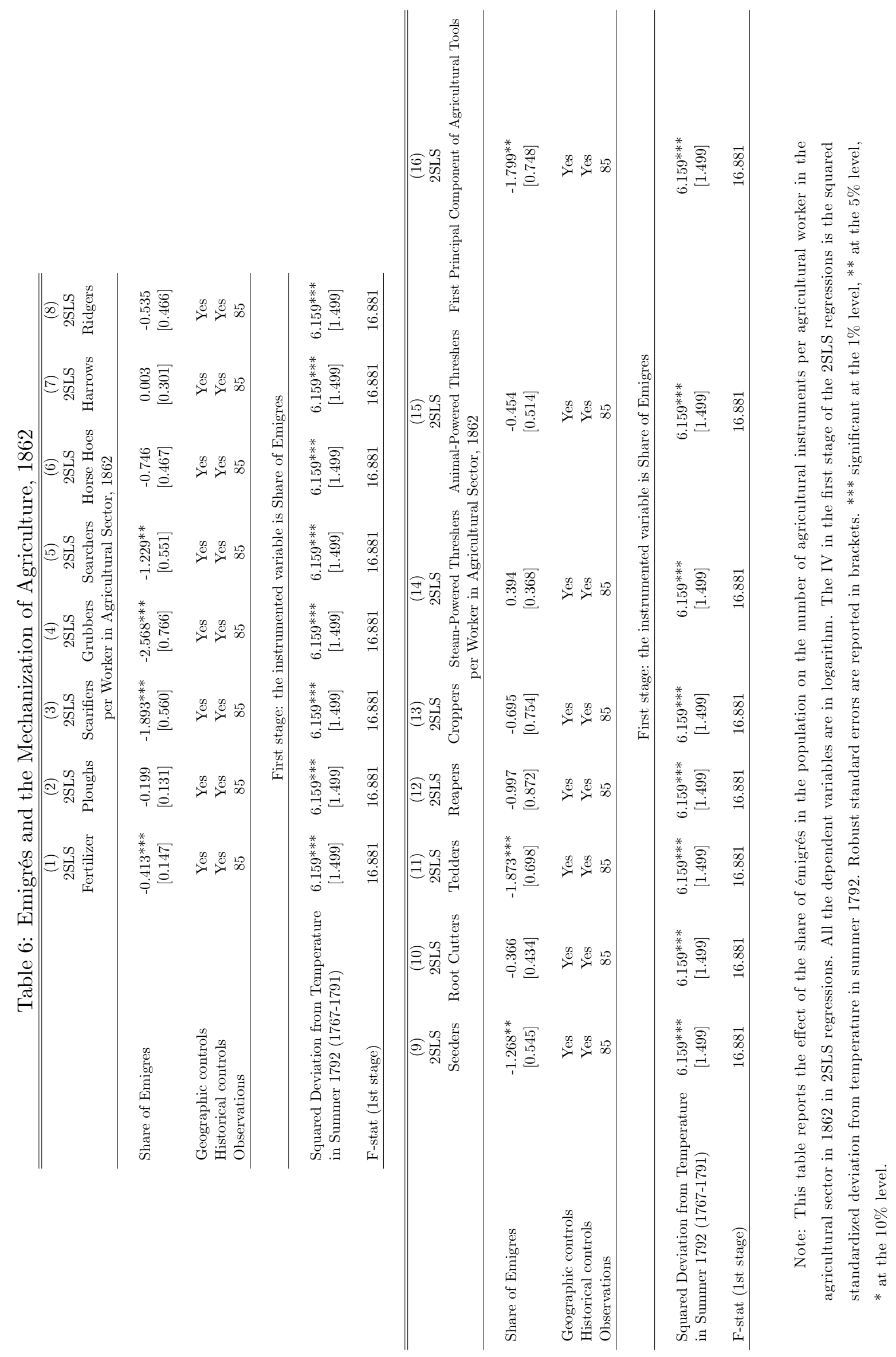


Table 7: Emigrés and Electors in 1839 under the Censitory Regime of the July Monarchy

\begin{tabular}{|c|c|c|c|c|c|}
\hline & $\begin{array}{c}\text { (1) } \\
\text { 2SLS } \\
\text { Share of Electors } \\
\text { in Department Population }\end{array}$ & $\begin{array}{c}\text { 2SLS } \\
\text { Share of Landowners } \\
\text { among Electors } \\
\end{array}$ & $\begin{array}{c}(3) \\
\text { 2SLS } \\
\text { Share of Businessmen } \\
\text { among Electors }\end{array}$ & $\begin{array}{c}\text { (4) } \\
\text { 2SLS } \\
\text { Share of Professionals } \\
\text { among Electors }\end{array}$ & $\begin{array}{c}(5) \\
\text { 2SLS } \\
\text { Share of Civil Servants } \\
\text { among Electors } \\
\end{array}$ \\
\hline Share of Emigres & $\begin{array}{c}-0.546^{* * *} \\
{[0.168]}\end{array}$ & $\begin{array}{c}-0.101^{* *} \\
{[0.048]}\end{array}$ & $\begin{array}{l}0.0917 \\
{[0.098]}\end{array}$ & $\begin{array}{c}0.147 \\
{[0.112]}\end{array}$ & $\begin{array}{c}0.425^{* *} \\
{[0.172]}\end{array}$ \\
\hline $\begin{array}{l}\text { Geographic controls } \\
\text { Historical controls } \\
\text { Observations }\end{array}$ & $\begin{array}{l}\text { Yes } \\
\text { Yes } \\
81\end{array}$ & $\begin{array}{l}\text { Yes } \\
\text { Yes } \\
67\end{array}$ & $\begin{array}{l}\text { Yes } \\
\text { Yes } \\
67 \\
\end{array}$ & $\begin{array}{l}\text { Yes } \\
\text { Yes } \\
67 \\
\end{array}$ & $\begin{array}{l}\text { Yes } \\
\text { Yes } \\
67 \\
\end{array}$ \\
\hline \multicolumn{6}{|c|}{ First stage: the instrumented variable is Share of Emigres } \\
\hline $\begin{array}{l}\text { Squared Deviation from Temperature } \\
\text { in Summer } 1792 \text { (1767-1791) }\end{array}$ & $\begin{array}{c}7.733^{* * *} \\
{[1.514]}\end{array}$ & $\begin{array}{c}7.872^{* * *} \\
{[1.600]}\end{array}$ & $\begin{array}{c}7.872^{* * *} \\
{[1.600]}\end{array}$ & $\begin{array}{c}7.872^{* * *} \\
{[1.600]}\end{array}$ & $\begin{array}{c}7.872^{* * *} \\
{[1.600]}\end{array}$ \\
\hline F-stat (1st stage) & 26.093 & 24.195 & 24.195 & 24.195 & 24.195 \\
\hline
\end{tabular}

Note: This table reports the effect of the share of émigrés in the population on the share of voters in the population and the shares of landowners, businessmen, professionals (i.e., lawyers and doctors), and civil servants among those voters in 1839, under the censitory regime of King Louis Philippe (1830-1848), in 2SLS regressions. All the dependent variables are in logarithm. The IV in the first stage of the 2SLS regressions is the squared standardized deviation from temperature in summer 1792. Robust standard errors are reported in brackets. $* * *$ significant at the $1 \%$ level, ${ }^{* *}$ at the $5 \%$ level, ${ }^{*}$ at the $10 \%$ level. 


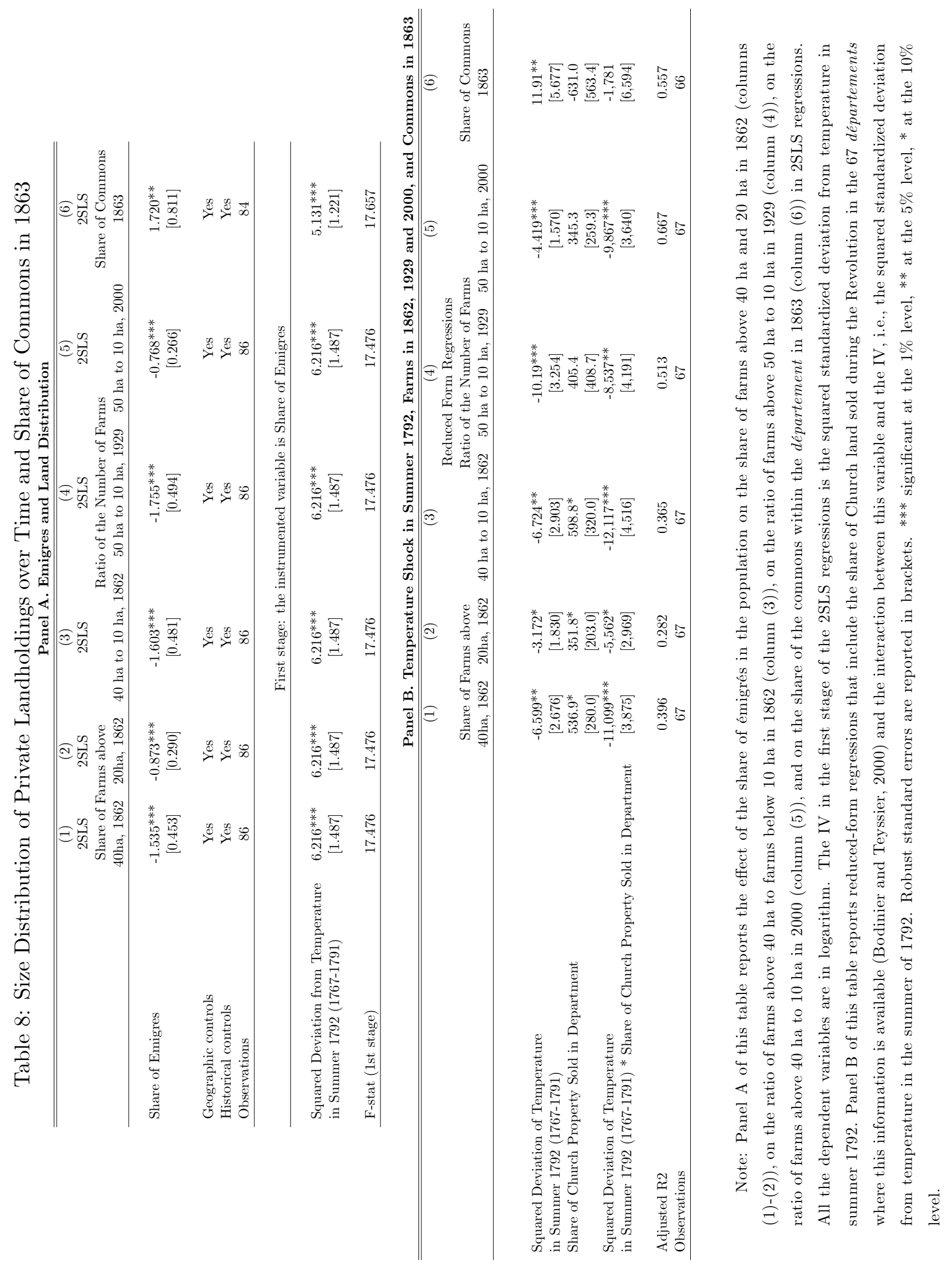


Table 9: Emigrés and the Share of Illiterate Army Conscripts

\begin{tabular}{|c|c|c|c|c|c|c|c|c|c|}
\hline & $\begin{array}{c}(1) \\
\text { SSIS }\end{array}$ & $\begin{array}{c}(2) \\
\text { (SIS }\end{array}$ & $\begin{array}{c}(3) \\
2 S L S\end{array}$ & $\begin{array}{c}(4) \\
\text { (S) }\end{array}$ & $\begin{array}{c}5) \\
\text { (5I S }\end{array}$ & $\begin{array}{c}(6) \\
S I S\end{array}$ & $\begin{array}{c}(7) \\
\text { (SIS }\end{array}$ & $\begin{array}{c}(8) \\
\text { (8IS }\end{array}$ & $\begin{array}{c}(9) \\
S I S\end{array}$ \\
\hline & \multicolumn{9}{|c|}{ Share of Illiterate Conscripts by Decade } \\
\hline & $1840 \mathrm{~s}$ & $1850 \mathrm{~s}$ & $1860 \mathrm{~s}$ & $1870 \mathrm{~s}$ & $1880 \mathrm{~s}$ & $1890 \mathrm{~s}$ & $1900 \mathrm{~s}$ & $1910 \mathrm{~s}$ & $1930 \mathrm{~s}$ \\
\hline Share of Emigres & $\begin{array}{r}-0.330^{*} \\
{[0.185]}\end{array}$ & $\begin{array}{l}-0.285 \\
{[0.183]}\end{array}$ & $\begin{array}{l}-0.260 \\
{[0.214]}\end{array}$ & $\begin{array}{c}-0.460^{*} \\
{[0.241]}\end{array}$ & $\begin{array}{l}-0.342 \\
{[0.250]}\end{array}$ & $\begin{array}{l}-0.318 \\
{[0.290]}\end{array}$ & $\begin{array}{c}-0.543^{* *} \\
{[0.254]}\end{array}$ & $\begin{array}{c}-0.605^{* *} \\
{[0.246]}\end{array}$ & $\begin{array}{c}-0.343^{* * *} \\
{[0.109]}\end{array}$ \\
\hline Geographic controls & Yes & Yes & Yes & Yes & Yes & Yes & Yes & Yes & Yes \\
\hline Historical controls & Yes & Yes & Yes & Yes & Yes & Yes & Yes & Yes & Yes \\
\hline \multirow[t]{2}{*}{ Observations } & 84 & 84 & 86 & 86 & 84 & 84 & 84 & 84 & 86 \\
\hline & \multicolumn{9}{|c|}{ First stage: the instrumented variable is Share of Emigres } \\
\hline $\begin{array}{l}\text { Squared Deviation from Temperature } \\
\text { in Summer } 1792(1767-1791)\end{array}$ & $\begin{array}{c}6.834^{* * *} \\
{[1.547]}\end{array}$ & $\begin{array}{c}6.834^{* * *} \\
{[1.547]}\end{array}$ & $\begin{array}{c}6.216^{* * *} \\
{[1.487]}\end{array}$ & $\begin{array}{c}6.216^{* * *} \\
{[1.487]}\end{array}$ & $\begin{array}{c}5.131^{* * *} \\
{[1.221]}\end{array}$ & $\begin{array}{c}5.131^{* * *} \\
{[1.221]}\end{array}$ & $\begin{array}{c}5.131^{* * *} \\
{[1.221]}\end{array}$ & $\begin{array}{c}5.131^{* * *} \\
{[1.221]}\end{array}$ & $\begin{array}{c}6.216^{* * *} \\
{[1.487]}\end{array}$ \\
\hline F-stat (1st stage) & 19.515 & 19.515 & 17.476 & 17.476 & 17.657 & 17.657 & 17.657 & 17.657 & 17.476 \\
\hline
\end{tabular}

Note: This table reports the effect of the share of émigrés in the population on the share of illiterate French army conscripts, i.e., 20-year-old men who reported for military service in the département where their father lived, in 2SLS regressions. All the dependent variables are in logarithm. The IV in the first stage of the 2SLS regressions is the squared standardized deviation from temperature in the summer of 1792 . Robust standard errors are reported in brackets. ${ }^{* * *}$ significant at the $1 \%$ level, ${ }^{* *}$ at the $5 \%$ level, * at the $10 \%$ level. 


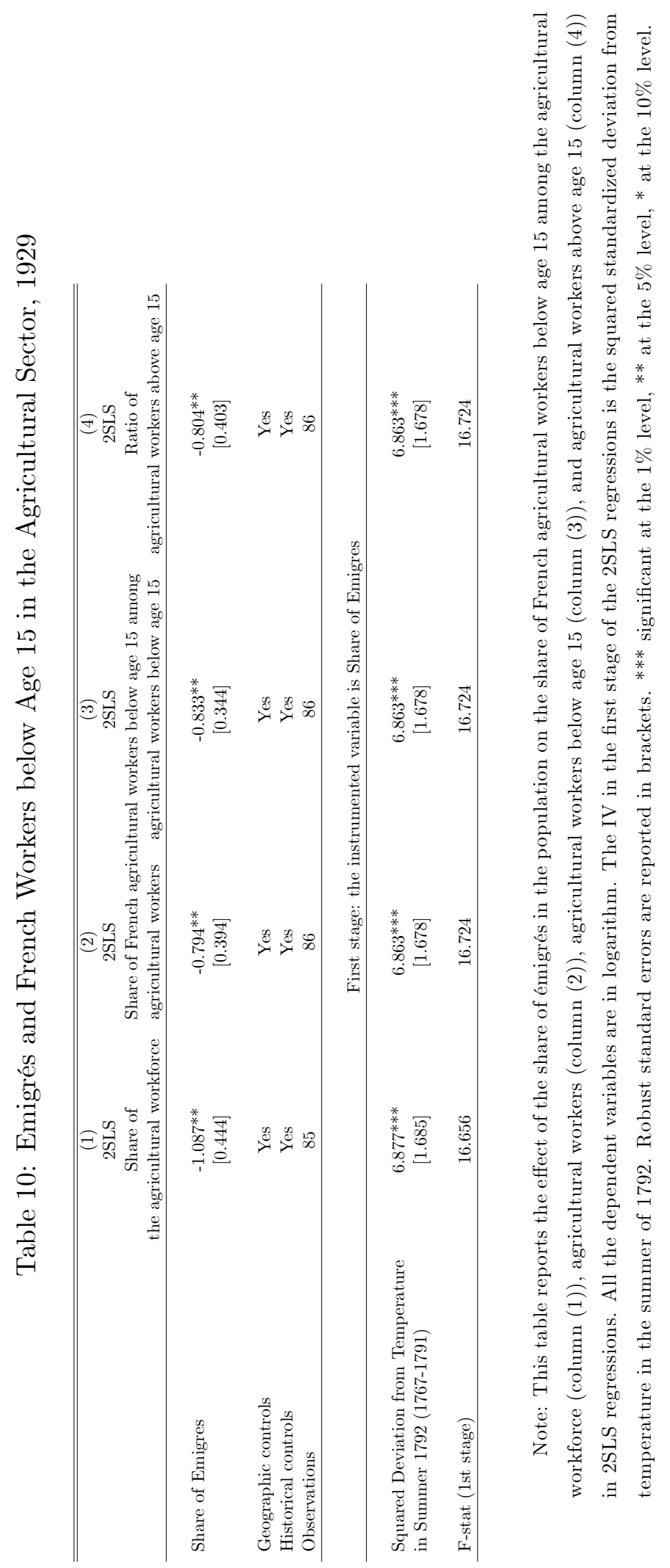




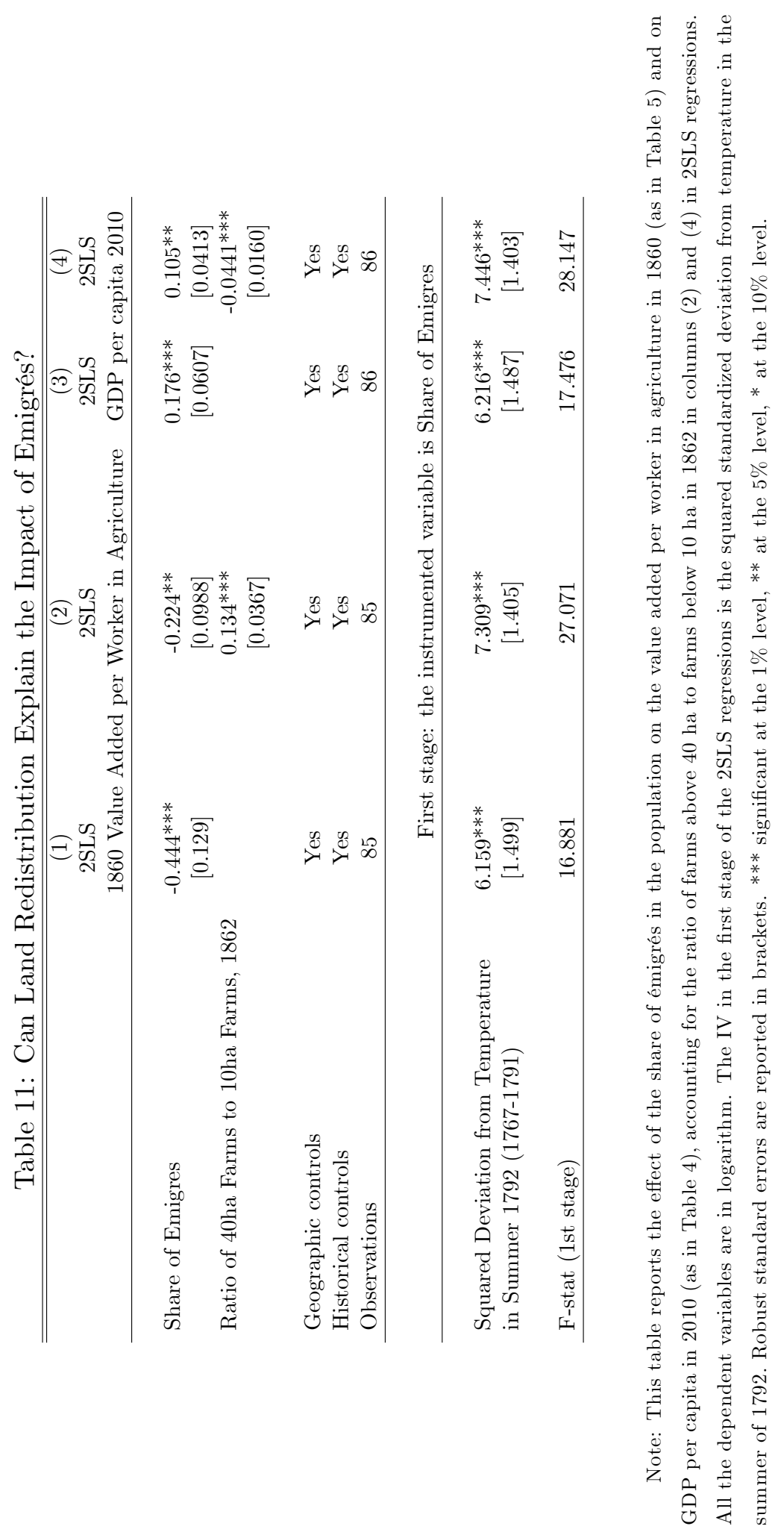




\section{Appendix for Online Publication}

\section{A. Historical Background}

\section{A.1 The Origins of the French Revolution}

Most historians now agree on the immediate causes of the French Revolution. The Old Regime experienced a fiscal crisis in the late 1780s, resulting mainly from the French support to the American War of Independence and by an inefficient tax system in need of reform. The crisis was exacerbated by two consecutive years of bad harvests and peasant revolts in 1788 and 1789 (see, e.g., Aftalion (1990), Balla and Johnson (2009), Waldinger (2014), and Tackett (2015) for a discussion).

However, the structural causes of the French Revolution are still debated. Some historians emphasize the rise of the bourgeoisie, while others stress the conflicts within the nobility and the Third Estate (Furet (1978)). Such a debate is keenly related to the importance of ideas in the unfolding of events and, in particular, to the violence of the French Revolution, leading to a declaration of war against foreign countries and to internal conflict. As noted by Israel (2014), there were revolts before and after the French Revolution which did not have major political and economic consequences: it is therefore difficult to argue that ideas would not play a role in the deeper roots of the French Revolution and the outbreak of revolutionary violence. These ideas include the development of a French national identity encouraged by the monarchy in the wake of the defeat in the Seven Years' War (1756-1763) as well as the development over two centuries of a national state with a centralized administration which gradually rendered local aristocrats, who used to serve as local justice officers, costly and redundant (Tocqueville (1856)). These ideas also relate to the Enlightenment philosophers and their revolutionary disciples. Enlightenment philosophers dismissed revealed religions and criticized existing social and political hierarchies, but they were oblivious to their optimistic faith in reason, nature and people. ${ }^{31}$ When every revolutionary thought that he represented the "people", and that his actions were guided by the "will of the people," he then felt legitimized in using violence so that his revolutionary ideas would prevail. $^{32}$ According to Furet (1978) this also explains the obsession of revolutionaries with treasons and conspiracies: the revolution was inherently good, seen as freeing the entire population from tyranny, and therefore, only hidden and evil forces would oppose it. This "revolutionary

\footnotetext{
${ }^{31}$ On the philosophy of Enlightenment, see, for example, Cassirer (1932 [2009]) as well as Gay (1966) and Gay (1969). On the relationship between Enlightenment philosophy and the revolution, see notably Mornet (1933) and Martin (2006), and specifically Koyré (1948) on Condorcet, the only Enlightenment philosopher who took an active part in the Revolution.

${ }^{32}$ For instance, in 1782, future revolutionary leader Jean-Louis Carra published a book where he advocated violence to overthrow "superstition" and "tyranny" (Carra (1782)). Another telling example can be found in the Instruction written to the soldiers on 26 Brumaire Year II (November 16, 1793) by Comité du Salut Public member Jean-Marie Collot d'Herbois as they quelled the revolt in Lyon: "Everything is permissible for those who act in service of the revolution" (Tout est permis pour ceux qui agissent dans le sens de la révolution). On the repression carried out by Collot d'Herbois in Lyon, see, for example, Palmer (1941) and Biard (1995).
} 
mentality" (Vovelle (1985)) may rationalize the revolutionaries' obsession with finding culprits and conspirators among their royalist opponents but also amidst the most devoted in their own ranks. ${ }^{33}$

\section{A.2 The "Second Revolution"}

During the summer of 1792, France experienced political turmoil and widespread agitation that would lead to the collapse of the House of Bourbon. The Legislative Assembly had declared war on April 20, 1792, against Austria. France attacked the Austrian Netherlands, but Prussia joined forces with Austria and, at first, the French army suffered losses. These foreign armies were thought to be preparing to invade France, and rumors spread among the Parisian population that nobles and priests were plotting with the leaders of the foreign armies. The Brunswick Manifesto, issued on July 25, 1792, by Charles William Ferdinand, Duke of Brunswick and commander of the armies allied against France, heightened the tensions as it threatened that Parisian civilians would be held personally responsible and tried in a military court if the members of the French royal family were harmed. While this measure was intended to intimidate the French revolutionaries, it only galvanized them. On August 10, 1792, the radical Parisian sans-culottes, supported by volunteers from Brittany and the South of France, attacked the King's castle and jailed Louis XVI and his family. As rumors of foreign invasion intensified, aristocrats and priests who were thought to be a part of the conspiracy against the revolution became targets of violence.

On September 2-6, 1792, the radical sans-culottes, who were mostly of bourgeois background, slaughtered aristocrats and clergy members who were imprisoned in the Parisian jails, along with petty thieves and prostitutes (Soboul (1958)). Similar episodes of violence occurred in various parts of France (Caron (1935), Bluche (1992), Markoff (1996)). Some of this violence was caused by peasant revolts, which were exacerbated by the July 22, 1792, decree pertaining to mass conscription, as well as by the June 18, 1792, and August 25, 1792, laws, which subordinated the payments of feudal dues to the presentation of the primal titles (Peyrard (1996), pp. 107-114, Ado (1987 [2012]), pp. 311-322). The war took a different turn with the victory of the French revolutionary army on September 20, 1792, at Valmy. The following day, the monarchy was abolished and the republic proclaimed. The trial of King Louis XVI began on December 11, 1792. On January 20, 1793, the members of the National Convention voted 380 to 310 in favor of his execution, and he was guillotined the next day.

\section{A.3 Primary School Provision during the 19th Century}

Under the Old Regime, the French state barely intervened in primary schooling and let the Church organize its own network of primary schools (Lebrun, Quéniart, and Venard (2003)). The

\footnotetext{
${ }^{33}$ As revolutionary leader Jacques-Pierre Brissot exclaimed in a 1791 speech: "We need great treasons" (Nous avons besoin de grandes trahisons) (Brissot (1792)).
} 
French Revolution harmed the Catholic school system, but the successive French rulers between 1799 and 1830 (Napoléon Bonaparte, 1799-1815, Louis XVIII, 1815-1824, Charles X, 1824-1830) enabled the Church to (re-)develop its educational network. After 1830, the French political regimes (the July Monarchy under King Louis-Philippe I, 1830-1848, the Second Republic, 18481852, and the Second Empire, 1852-1870) were less favorable to the Church, but education laws which were passed under those regimes fostered the development of Catholic schools. Thus, François Guizot, who was King Louis-Philippe I's prime minister, reshaped the organization of schooling in France with the June 28, 1833, law that compelled all French communes to host a primary school in their jurisdiction. This law enabled the Church to organize its own private education system, but also to retain its control over public schooling. In particular, monks and nuns could be employed as teachers in public schools while religious instruction remained mandatory During the Second Republic, Education Minister Alfred de Falloux passed the March 15, 1850 law and the August 27, 1851, regulation that favored the Church since towns would not have to fund a public school if a private (i.e., Catholic) school already operated in their jurisdiction. Besides, all teachers had to fulfill the duties prescribed by the Church. Finally, Catholic secondary schools could compete with public secondary schools and could still receive subsidies from the State and from the local governments.

Nonetheless, the political stance of the Catholic Church led to a conflict on education against the French state which reached its apex after the establishment of the Third Republic in 1875. The Republicans, who opposed the Catholic Church for its support for the Royalist politicians, first weakened the Catholic educational system in the 1880s and 1890s before separating Church and State in 1905. See, for example, Mayeur (2003), Franck and Johnson (2016), and Franck and Galor (2017) for recent studies on this issue.

\section{B. Temperature Shocks, Wheat Prices, Local Violence, and Emigration}

\section{B.1. The Impact of Temperature Shocks on Wheat Prices}

In late 18th-century France, there is ample anecdotal evidence suggesting that abnormal weather conditions would negatively impact crops and in particular wheat production, which was the main crop cultivated and consumed in most French départements (Kaplan (1984), Kaplan (1996)). Late spring and summer climatic conditions are important determinants of the winter wheat yields (Triticum aestivum), which is planted in the fall and harvested in the summer or early autumn of the following year. ${ }^{34}$

When local markets are not perfectly integrated, local wheat prices are likely to respond to local yield fluctuations, increasing the probability of social agitation when prices rise. ${ }^{35}$ Anecdotal

\footnotetext{
${ }^{34} \mathrm{On}$ the growth and developmental stages of wheat and the impact of weather conditions, see, for example, Haun (1973) and Zadoks, Chang, and Konzak (1974).

${ }^{35}$ On market integration (and lack thereof) during the Revolution, see, for example, Daudin (2010).
} 
evidence from historians such as Soboul (1962) (pp.342-346) and Johnson (1986) (p.256) are consistent with this reality. ${ }^{36}$ Unfortunately, there are no comprehensive data on wheat prices for 1792, but such data do exist for 1797-1800, that is, for the later part of the Revolution (Labrousse, Romano, and Dreyfus (1970)). This allows us to run panel-level regressions where the price of wheat in each département is linked to the temperature shocks in the summer in that département over the 1797-1800 period:

$$
P_{d, t}=\alpha_{d}+\alpha_{t}+\alpha_{1} Z_{d, t}+u_{d, t}
$$

where $P_{d, t}$ is the price of wheat in département $d$ in year $t, Z_{d, t}$ is the temperature deviation in département $d$ in the summer of year $t, \alpha_{d}$ and $\alpha_{t}$ are département and year fixed effects, and $u_{d, t}$ is an error term for département $d$ in year $t$. We consider several specifications for $Z_{d, t}$ including the squared and absolute deviation defined in the main text. For completeness, we also constructed separate measures for positive (and negative) weather shocks to investigate whether wheat prices differentially respond to abnormally warm or cold summer temperatures.

We report the regression results in columns (1)-(5) of Table D.5. In the first column, our explanatory variable is the squared deviation from standardized temperature; this specification does not include département fixed effects so as to highlight the source of variation in our identification strategy. In columns (2)-(5) we include département-specific constants to account for any time-invariant département-level characteristics: the main explanatory variable is the squared deviation from standardized temperature in column (2), the absolute deviation from standardized temperature in column (3), the positive and negative squared deviations in column (4) and the positive and negative absolute deviations in column (5).

Reassuringly, increases in temperature shocks at the département level led systematically to higher wheat prices during the 1797-1800 period, consistent with an economy composed of relatively fragmented markets where local weather fluctuations have material local economic consequences. In Figure D.3 in Appendix D we plot the percentage change in yearly wheat prices between 1797 and 1798 and the difference in summer temperature shocks for the same period. There is a clearly positive relationship.

\section{B.2. The "Second Revolution": Violence and Emigration during the Summer of 1792}

To provide some support to the narrative that emigration in a département was partly driven by local violence resulting from abnormal weather conditions, we test whether the temperature shocks in the summer of 1792 are significantly related to local riots during the "Second

\footnotetext{
${ }^{36}$ In a study of the Revolution in the South of France between 1789 and 1793, Johnson (1986) writes (p.256): "The great concentration of violent episodes occurred in March 1789, July and August 1789, July 1791, March and April 1792, and July and August 1792. All occurred in either the spring or summer and were for the most part the results of poor harvests and food shortages."
} 
Revolution." For this purpose, we use the data from Markoff (1996), who provides information on local riots in August and September 1792, which we aggregate at the level of the département. We have information on 82 departements. The average département has 53.30 riots with a standard deviation of 193.65, a minimum of 0 , and a maximum of 1,489. In the OLS regressions, $R_{d}$ is the $\log$ of the number of riots in August and September 1792 in département d, and $Z_{d, 1792}$ is the squared (or absolute) deviation of temperature in the summer of 1792:

$$
R_{d}=\beta_{0}+\beta_{1} Z_{d, 1792}+\mathbf{X}_{d}^{\prime} \cdot \gamma+v_{d}
$$

where $\mathbf{X}_{d}^{\prime}$ is a vector of economic, geographical, and institutional characteristics of département $d$, and $v_{d}$ is an error term for département $d$.

We report the regression results in columns (6) and (7) of Table D.5 in Appendix D. Larger temperature shocks at the département level in the summer of 1792 lead systematically to more riots. Figure D.1 provides a graphical representation of the statistical association implied by column (6) in Table D.5. The evidence uncovered regarding the robust impact of abnormal temperatures on wheat prices and peasant revolts during the inflection point of the French Revolution, namely the summer of 1792 , increases our confidence regarding the plausibility of our identification strategy.

\section{B.3 First-Stage Robustness Checks: Temperature Shocks in the Summer of}

\section{2 and Emigration}

Given our reliance on the credibility of temperature shocks as a plausible source of variation for emigration during the Revolution, we have performed a comprehensive set of robustness checks. First, we show that the weather conditions in the summer of 1792 are the critical temperature shocks during the Revolution for understanding emigration. Second, in an attempt to mitigate concerns that our instrument correlates mechanically with preexisting measures of development (or other large-scale events after the end of the Revolution), we amassed a multitude of alternative indexes of social and economic significance, failing to find any systematic association.

Specifically, emigration rates are explained neither by deviations from temperatures in the spring, fall, or winter of 1792 in Table D.6, nor by deviations from temperatures in all the other summers between 1788 and 1800 in Table D.7 and Figure D.2. Also, we show in Table D.8 that squared and absolute deviations from standardized rainfall in the summer of 1792 do not explain variations in the share of émigrés. In Table D.9 we report the first-stage relationship between the squared temperature deviation in the summer of 1792 and the share of émigrés accounting for spatial dependence in the error structure (Conley (1999)). Moreover, in Table D.10, we show that our first-stage regression results are robust to using other baselines, such as a 50-year rolling window based on summer temperatures between 1747 and 1791, a couple of fixed 25-year windows 
(1751-1775 and 1776-1800), or a fixed 50-year window (1751-1800). Furthermore, in regressions available upon request, we show that deviations from temperature in the summers from 1788 to 1800 do not systematically map into variations in the number of death sentences across France during the 1793-1794 Reign of Terror (Greer (1935)). ${ }^{37}$ We also test in regressions available upon request additional specifications for the first-stage regression, finding that measures of abnormal temperatures other than the squared and absolute deviation of temperature in the summer of 1792 are less strongly correlated with the share of émigrés. In particular, we find that the one-sided deviation of temperature is only weakly correlated with the share of émigrés, thus suggesting that both higher and lower than average temperatures in the summer of 1792 contributed to the flight of the émigrés.

Moreover, we provide in Tables D.11, D.19, and D.20 several tests in support of the plausibility of the exclusion restriction. These tests are meant to show that our instrumental variable, the summer of 1792 temperature shock, is not correlated with variables which may potentially be correlated with emigration rates and the evolution of income per capita in the medium and long run. In Panel $A$ of Table D.11, we focus on violence before 1789 and after 1815, as proxied by the "flour war" of 1775 , which is viewed as the last major series of riots triggered by bad harvests and hunger before 1789 (Bouton (1993)), and by the post-1815 "white terror" when the royalist regime of Louis XVIII arrested and sentenced to death some of their revolutionary and Bonapartist opponents (Resnick (1966)). In Panel $B$ of Table D.11, we examine the demands of the French population in 1789 as expressed in the cahiers de doléances (Hyslop (1934), Shapiro and Markoff (1998)). We aggregate at the département level the number of times major political and economic issues were mentioned in the cahiers de doléances. ${ }^{38}$ Such issues include the approval of vote by head (a first step toward democratic voting which was in opposition to the vote by order as was the case under the Old Regime), state intervention in education, tendency to socialism, as well as the abolition of guilds, feudal dues, and serfdom. In Panel $C$ of Table D.11, we measure human capital before the Revolution proxied by the share of brides and grooms who could sign their wedding contracts over the 1686-1690 and 1786-1790 periods (Furet and Ozouf (1977)). Lastly, in Panel $D$ of Table D.11, we assess the presence of the clergy that was hostile to the Revolution, and the number of famous aristocratic families. We use the data from Tackett (1986) on the share of clergymen who refused to take the oath in support of the Constitution Civile du Clergé in 1791. As Tackett (1986) shows, this piece of legislation, which was hostile to the Catholic Church (Godechot (1951)), reflected not only the views of the local priests at the

\footnotetext{
${ }^{37}$ We find that the unconditional relationship between temperature deviation in the summer of 1792 is significantly and positively correlated at the $10 \%$ level with the share of death sentences during the Reign of Terror, but that this is driven by the number of death sentences in one département, Loire-Inférieure.

${ }^{38}$ Cahiers de doléances were redacted at the level of the baillage, which was an administrative division of France under the Ancien Régime.
} 
start of the Revolution but also those of the laypeople who pressured priests to accept or reject the oath, thereby providing a measure of the religiosity of the local population. In addition, we use information on the most prestigious noble families, as listed in the Almanach de Saxe Gotha, in 1750, which can be viewed as proxying for the higher ends of the stock of regional political and economic power (Squicciarini and Voigtländer (2015)). ${ }^{39}$

In Table D.19, we show that temperature shocks in the summer of 1792 are not correlated with variables that proxy religiosity during the long 19th century (see Franck and Johnson (2016) for a discussion): these are the number of religious communities in each département devoted to education, charity, and solely to religious purposes in 1856 (from the 1856 French census), as well as the share of representatives in the lower house of Parliament who voted against the separation of Church and State in 1905 (Franck (2010)). Finally, we examine in Table D.20 whether our instrument is correlated with the spread of the phylloxera in 1875 and 1890, a disease which was harmful to vine roots but also to the health of the people living in the regions hit more harshly (Banerjee, Duflo, Postel-Vinay, and Watts (2010)).

All in all, while information prior to 1789 at the département level on the number of priests, large landowners, and land distribution is missing, ${ }^{40}$ the results reported in Tables D.11, A.19, and D.20 are reassuring since none of the potentially important variables is correlated with our instrument. Indeed, if our instrument was systematically correlated with an economic and political factor related to the land distribution or the composition of the population before the Revolution, such a correlation would likely have been reflected in these observed traits including a culture of violence before, during, and after the Revolution, complaints in the cahiers de doléances, prerevolutionary human capital, local religiosity, and proxies for the presence of local elites.

\footnotetext{
${ }^{39}$ The data of Furet and Ozouf (1977) and Squicciarini and Voigtländer (2015) do not cover all the French départements and cannot therefore be included as part of the historical controls in our baseline regressions.

${ }^{40}$ While some attempts were made to survey the French population under the Old Regime, it was only under Napoleon Bonaparte's rule in 1801 that the first systematic count of the French population was undertaken (Dupâquier and Dupâquier (1985)). Still, it was only in 1851 that a survey offered for the first time systematic information on the professions of the inhabitants at the local level. Moreover, the cadastre, which registered property ownership at the local level, was also given an impulse under Napoleon Bonaparte's rule in 1807 but was only completed in 1850 (Bloch (1929)).
} 


\section{Figures and Tables}

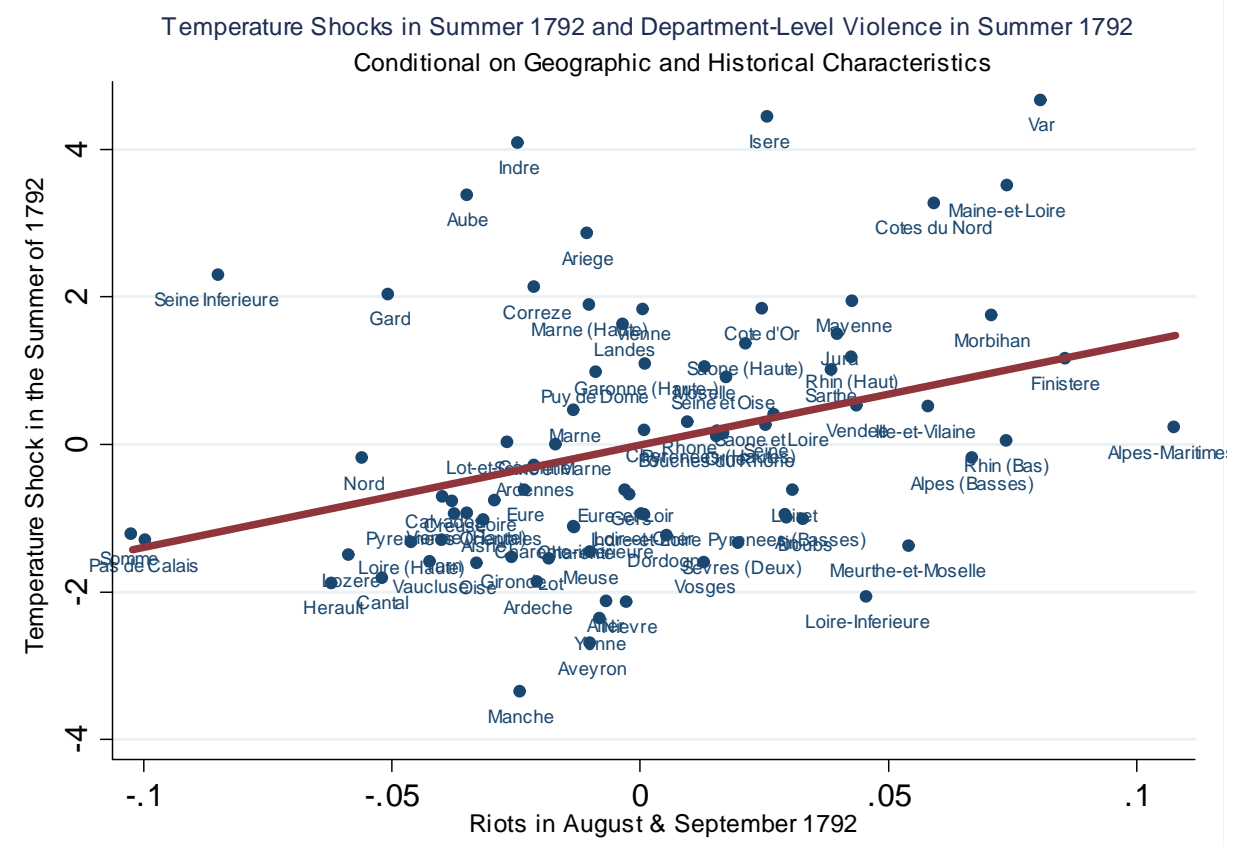

IV is the Squared Deviation from Temperature in Summer 1792

Figure D.1: Temperature Deviation in Summer 1792 and Local Violence in Summer 1792, Controlling for Geographic and Historical Characteristics

Note: This figure depicts the partial scatterplot of the effect of temperature shocks in the summer of 1792 on the logarithm of the number of riots in August and September 1792 in each French département. Thus, the $\mathrm{x}$ - and $\mathrm{y}$-axes plot the residuals obtained from regressing the logarithm of the number of riots in August and September 1792 against the squared deviation from temperature in the summer of 1792 , conditional on geographic and historical controls. 


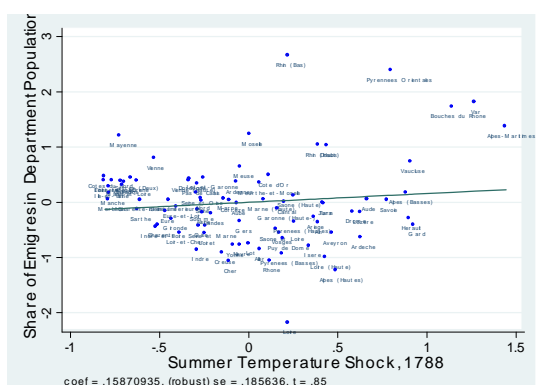

coet $=.15870935$, (nobust) $s e=.185636, t=.85$
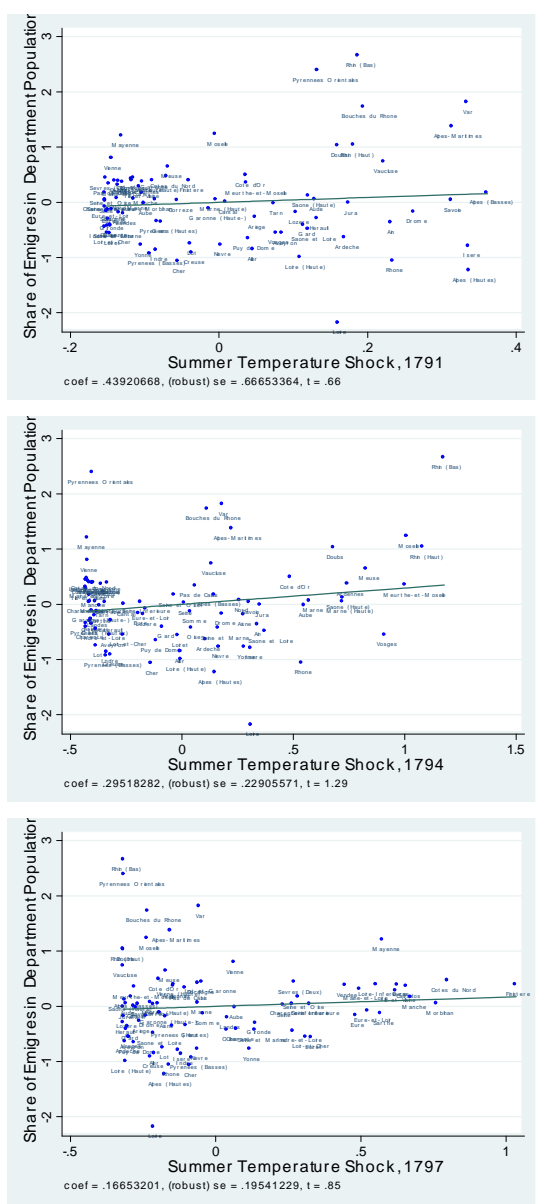
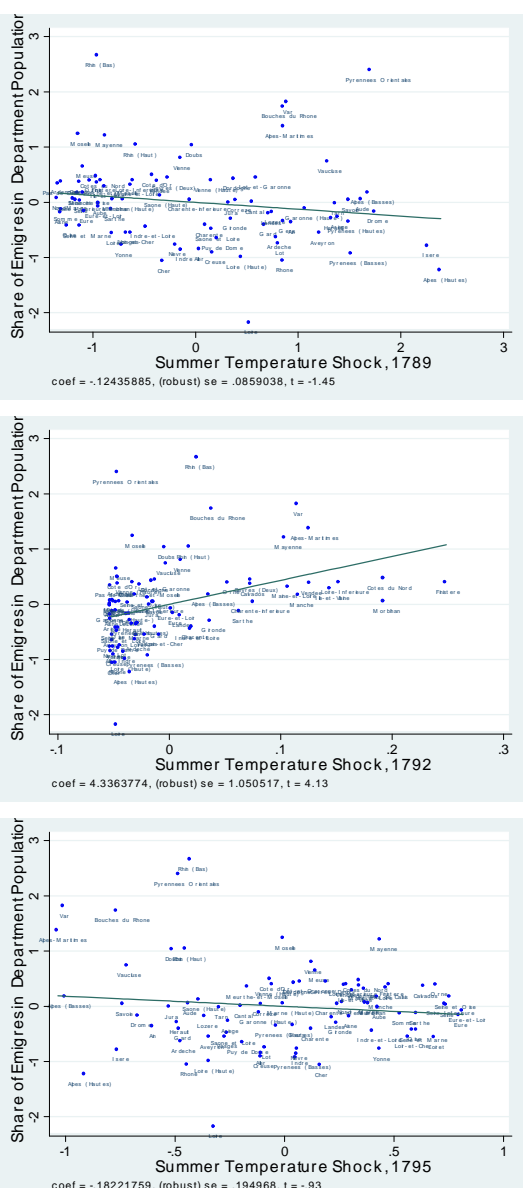

coef $=. .18221759$, (robust) se $=.194968, t=.93$

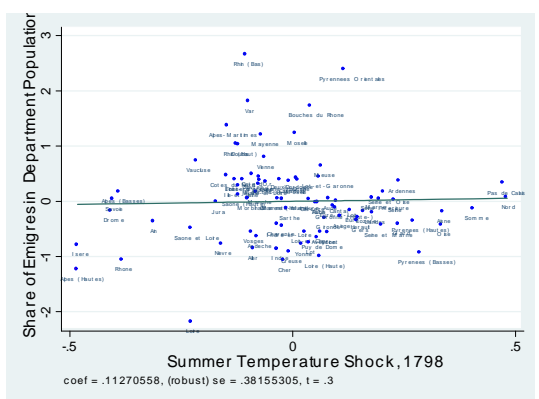

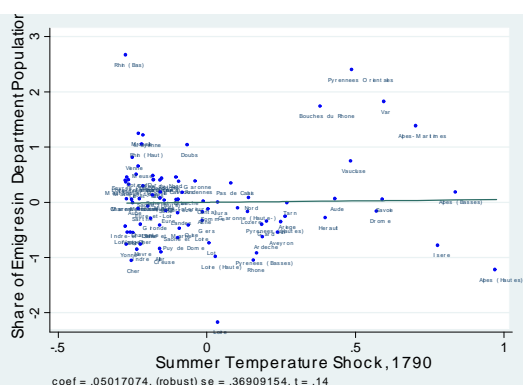
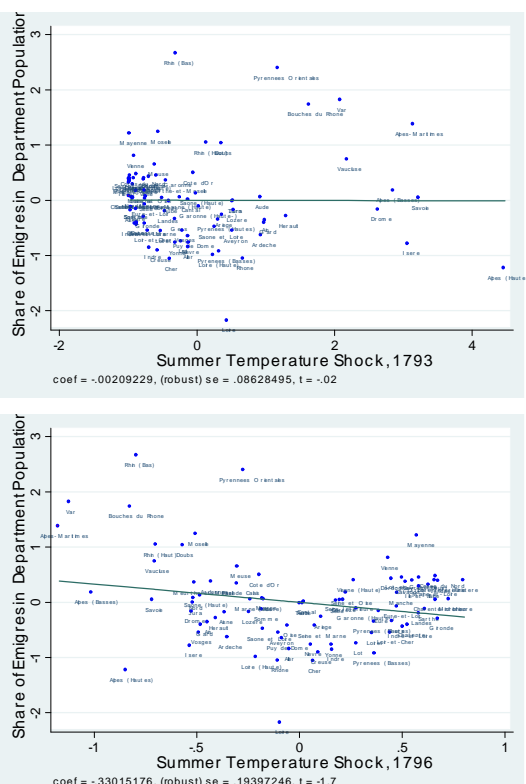

coet =

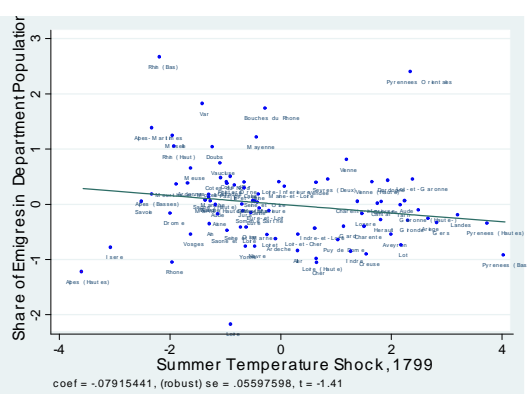

Figure D.2: Unconditional Correlation between the Squared Deviation from Temperature in Summers 1788-1799 and the Share of Emigrés in the Population

Note: This figure graphs the relationship between the squared deviation from standardized temperature in all the summers between 1788 and 1799 and the share of émigrés in the population. It shows that the negative and significant relationship between the squared deviation from standardized temperature in the summer of 1792 and the share of émigrés does not hold for any other summer between 1788 and 1799 . 
Wheat Prices Chang es and Differences in Summer Temp. Shocks 1797-1798

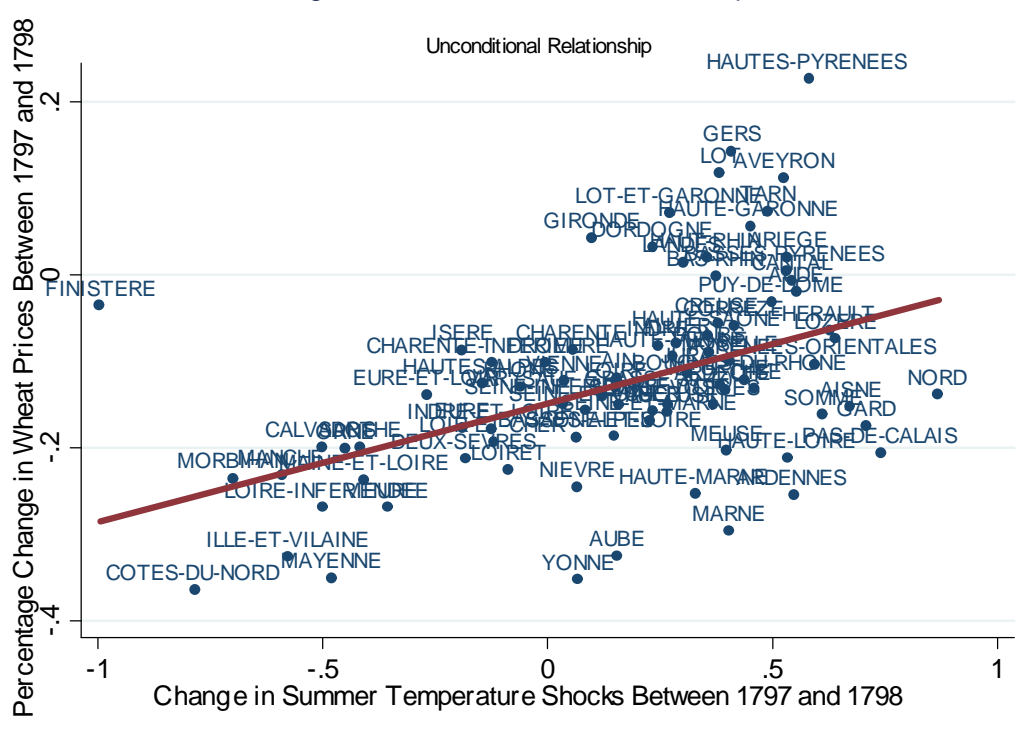

Wheat Price Changes,1797-1798

Figure D.3: Wheat Price Changes and Differences in Summer Temperature Shocks, 1797-1798

Note: This figure graphs the relationship between the change in the summer temperature shocks between 1797 and 1800 and the percent change in wheat prices between 1797 and 1798 . 


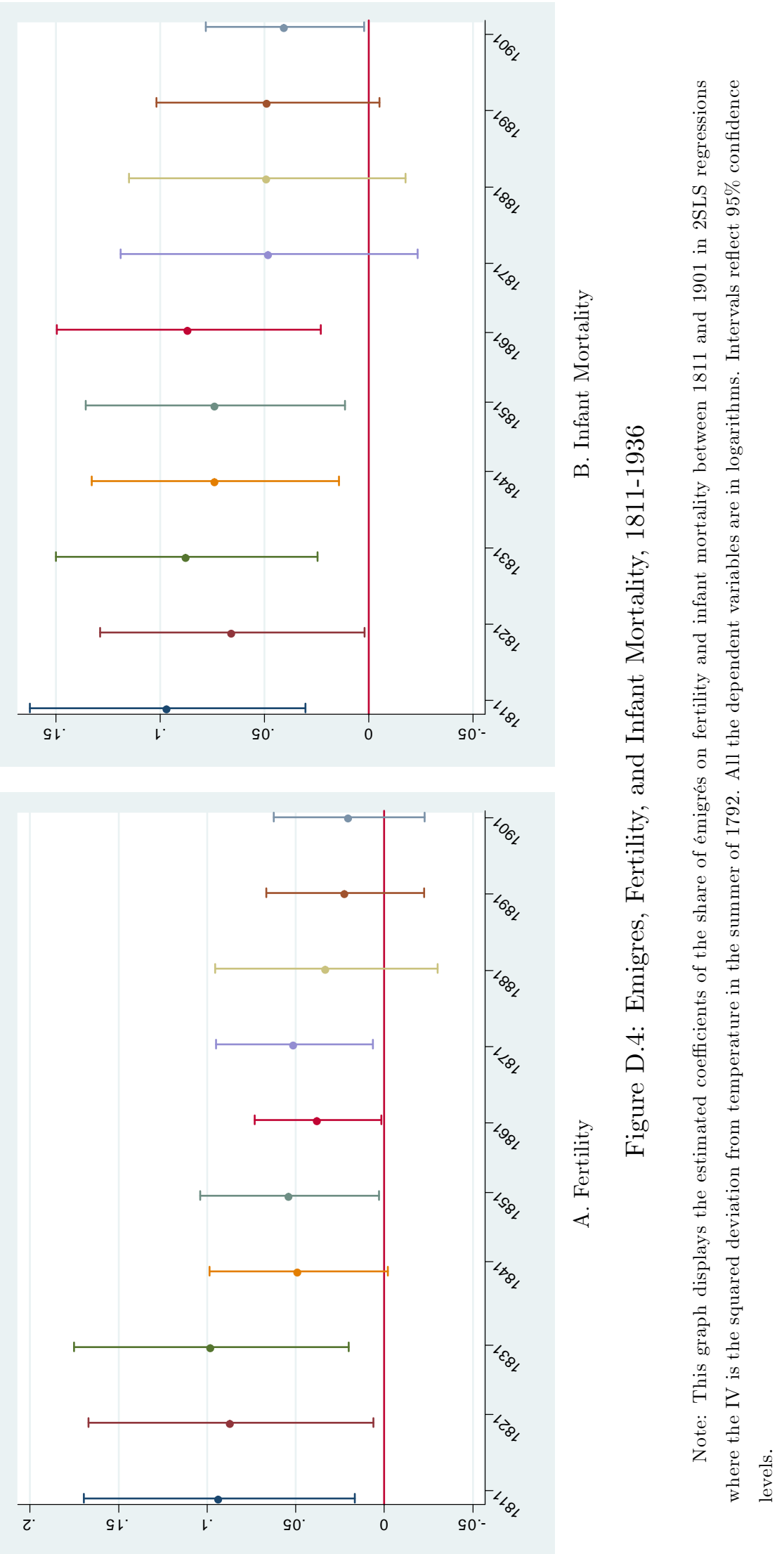



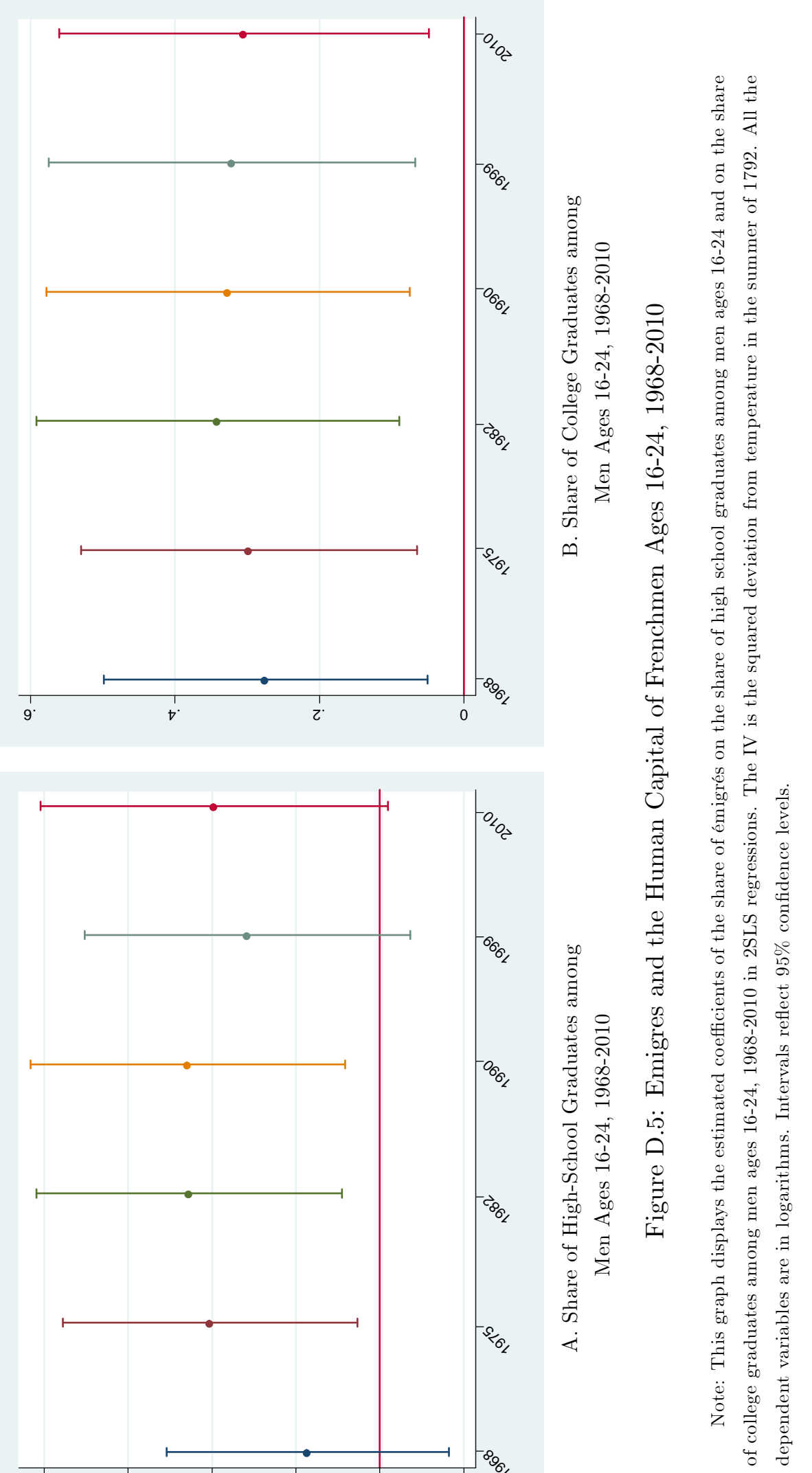
Table D.1: Average Farm Size in France in 1862 and in the USA in 1860

\begin{tabular}{|c|c|c|c|c|c|c|}
\hline & Observations & Mean & Median & Std.Dev. & Min. & Max. \\
\hline \multicolumn{7}{|l|}{ Average Farm Size, France, 1862} \\
\hline Average Farm Size & 88 & 23.12 & 18.12 & 13.14 & 4.57 & 62.83 \\
\hline Average Farm Size, Above Median Temperature Shock in Summer 1792 & 43 & 27.35 & 25.98 & 14.39 & 7.97 & 62.83 \\
\hline Average Farm Size, Below Median Temperature Shock in Summer 1792 & 45 & 17.02 & 19.08 & 10.46 & 4.57 & 49.80 \\
\hline Average Farm Size, Above Median Wheat Production 1862 & 44 & 29.86 & 28.51 & 13.20 & 8.56 & 62.83 \\
\hline Average Farm Size, Below Median Wheat Production 1862 & 44 & 16.38 & 14.47 & 9.05 & 4.57 & 49.27 \\
\hline \multicolumn{7}{|l|}{ Average Farm Size, USA, 1860} \\
\hline Average Farm Size & 1944 & 336.17 & 562.54 & 218.64 & 10.78 & 15172.6 \\
\hline Average Farm Size, Above Median Wheat Production 1860 & 979 & 248.49 & 189.38 & 301.30 & 10.78 & 5610.0 \\
\hline Average Farm Size, Below Median Wheat Production 1860 & 964 & 425.42 & 291.56 & 728.33 & 11.71 & 15172.6 \\
\hline \multicolumn{7}{|l|}{ Average Farm Size, France 1862, Excluding Farms below 5 ha $(=12.36$ acres $)$} \\
\hline Average Farm Size, Excluding Farms below 5 ha (=12.36 acres) & 88 & 102.99 & 78.59 & 91.33 & 36.32 & 705.58 \\
\hline Average Farm Size, Excluding Farms below 5 ha (=12.36 acres), Above Median Temperature Shock in Summer 1792 & 43 & 107.01 & 92.09 & 81.61 & 46.33 & 484.77 \\
\hline Average Farm Size, Excluding Farms below 5 ha (=12.36 acres), Below Median Temperature Shock in Summer 1792 & 45 & 99.16 & 75.48 & 100.51 & 36.32 & 705.58 \\
\hline Average Farm Size, Excluding Farms below 5 ha (=12.36 acres), Above Median Wheat Production 1862 & 44 & 108.74 & 78.98 & 107.87 & 42.29 & 705.58 \\
\hline Average Farm Size, Excluding Farms below 5 ha (=12.36 acres), Below Median Wheat Production 1862 & 44 & 97.25 & 77.91 & 71.91 & 36.32 & 484.77 \\
\hline \multicolumn{7}{|l|}{ Average Farm Size, USA 1860, Excluding Farms Below 9 acres } \\
\hline Average Farm Size Excluding Farms Below 9 acres & 1944 & 354.74 & 231.11 & 639.89 & 12.14 & 17403.0 \\
\hline Average Farm Size, Excluding Farms Below 9 acres, Above Median Wheat Production 1860 & 979 & 256.89 & 194.18 & 310.37 & 12.14 & 5610.0 \\
\hline Average Farm Size, Excluding Farms Below 9 acres, Below Median Wheat Production 1860 & 965 & 454.00 & 309.44 & 841.41 & 26.00 & 17403.0 \\
\hline
\end{tabular}

Note: Farm size is measured in acres. 
Table D.2: Descriptive Statistics

\begin{tabular}{|c|c|c|c|c|c|}
\hline & Obs. & Mean & Std.Dev & Min. & Max. \\
\hline \multicolumn{6}{|l|}{ Explanatory variables } \\
\hline Share of Emigres in Population & 86 & 0.0047 & 0.0064 & 0.00 & 0.05 \\
\hline Altitude & 88 & 353.37 & 344.24 & 36.02 & 1729.22 \\
\hline Land Suitability & 88 & 0.75 & 0.19 & 0.21 & 0.98 \\
\hline Latitude & 88 & 46.54 & 2.11 & 42.60 & 50.49 \\
\hline Longitude & 88 & 2.62 & 2.66 & -4.06 & 7.55 \\
\hline Distance to Paris & 88 & 357.07 & 178.66 & 0.00 & 693.86 \\
\hline Distance to Lyon & 88 & 322.25 & 145.85 & 0.00 & 709.62 \\
\hline Distance to Marseille & 88 & 448.50 & 210.44 & 0.00 & 879.23 \\
\hline Department Area & 88 & 618807.00 & 148900.10 & 61087.20 & 1084890.00 \\
\hline Distance to Border & 88 & 191.11 & 134.17 & 16.56 & 557.59 \\
\hline Distance to Coast & 88 & 159.54 & 111.61 & 10.42 & 411.07 \\
\hline Temperature in Summer 1792 & 88 & 17.97 & 1.36 & 13.69 & 21.82 \\
\hline Lack of Commons in Department & 88 & 0.32 & 0.47 & 0 & 1 \\
\hline Mechanical Mills 1789 & 88 & 0.08 & 0.31 & 0 & 2 \\
\hline Encyclopedie Subscribers & 86 & 1.00 & 0.00 & 1 & 1.00 \\
\hline University in 1700 & 88 & 0.18 & 0.39 & 0 & 1 \\
\hline \multicolumn{6}{|l|}{ GDP per capita } \\
\hline GDP per capita 1860 & 87 & 498.18 & 144.20 & 273.00 & 1105.00 \\
\hline GDP per capita 1901 & 86 & 863.42 & 269.40 & 255.30 & 1816.40 \\
\hline GDP per capita 1930 & 87 & 6464.61 & 1500.21 & 4033.47 & 14109.90 \\
\hline GDP per capita 1995 & 88 & 17.64 & 3.17 & 13.23 & 38.83 \\
\hline GDP per capita 2000 & 88 & 20.37 & 3.99 & 15.49 & 47.72 \\
\hline GDP per capita 2010 & 88 & 24.65 & 5.60 & 18.36 & 63.22 \\
\hline \multicolumn{6}{|l|}{ Value added by workforce in each sector } \\
\hline 1860 Value Added per Worker in Agriculture & 87 & 0.00 & 0.00 & 0.00 & 0.00 \\
\hline 1930 Value Added per Worker in Agriculture & 87 & 0.01 & 0.00 & 0.00 & 0.02 \\
\hline 1982 Value Added per Worker in Agriculture & 88 & 3699.27 & 6510.40 & 225.52 & 55433.29 \\
\hline 1990 Value Added per Worker in Agriculture & 88 & 6069.24 & 6372.52 & 320.53 & 36589.30 \\
\hline 1860 Value Added per Worker in Industry & 87 & 0.00 & 0.00 & 0.00 & 0.00 \\
\hline 1930 Value Added per Worker in Industry & 87 & 0.02 & 0.00 & 0.01 & 0.03 \\
\hline 1982 Value Added per Worker in Industry & 88 & 5182.49 & 9865.68 & 304.84 & 88828.12 \\
\hline 1990 Value Added per Worker in Industry & 88 & 10524.74 & 23123.32 & 685.78 & 210220.80 \\
\hline 1860 Value Added per Worker in Services & 87 & 0.00 & 0.00 & 0.00 & 0.00 \\
\hline 1930 Value Added per Worker in Services & 87 & 0.01 & 0.00 & 0.01 & 0.02 \\
\hline 1982 Value Added per Worker in Services & 88 & 6716.78 & 12338.99 & 670.73 & 111846.40 \\
\hline 1990 Value Added per Worker in Services & 88 & 10455.12 & 20475.20 & 1034.12 & 186043.20 \\
\hline \multicolumn{6}{|c|}{ Workforce in agriculture, industry and services } \\
\hline Share of the Workforce in Agriculture 1860 & 87 & 0.63 & 0.16 & 0.01 & 0.89 \\
\hline Share of the Workforce in Agriculture 1930 & 87 & 0.45 & 0.16 & 0.00 & 0.73 \\
\hline Share of the Workforce in Agriculture 1982 & 88 & 0.13 & 0.07 & 0.00 & 0.34 \\
\hline Share of the Workforce in Agriculture 1990 & 88 & 0.09 & 0.05 & 0.00 & 0.26 \\
\hline Share of the Workforce in Agriculture 1999 & 88 & 0.07 & 0.04 & 0.00 & 0.19 \\
\hline Share of the Workforce in Agriculture 2010 & 88 & 0.22 & 0.09 & 0.00 & 0.47 \\
\hline Share of the Workforce in Industry 1860 & 87 & 0.22 & 0.11 & 0.06 & 0.52 \\
\hline Share of the Workforce in Industry 1930 & 87 & 0.30 & 0.11 & 0.13 & 0.63 \\
\hline Share of the Workforce in Industry 1982 & 88 & 0.34 & 0.07 & 0.20 & 0.49 \\
\hline Share of the Workforce in Industry 1990 & 88 & 0.31 & 0.06 & 0.15 & 0.44 \\
\hline Share of the Workforce in Industry 1999 & 88 & 0.26 & 0.05 & 0.14 & 0.36 \\
\hline Share of the Workforce in Industry 2010 & 88 & 0.23 & 0.03 & 0.14 & 0.33 \\
\hline Share of the Workforce in Services 1860 & 87 & 0.15 & 0.07 & 0.05 & 0.47 \\
\hline Share of the Workforce in Services 1930 & 87 & 0.25 & 0.08 & 0.13 & 0.54 \\
\hline Share of the Workforce in Services 1982 & 88 & 0.53 & 0.07 & 0.40 & 0.71 \\
\hline Share of the Workforce in Services 1990 & 88 & 0.60 & 0.06 & 0.47 & 0.76 \\
\hline Share of the Workforce in Services 1999 & 88 & 0.68 & 0.06 & 0.57 & 0.85 \\
\hline Share of the Workforce in Services 2010 & 88 & 0.53 & 0.09 & 0.37 & 0.86 \\
\hline
\end{tabular}


Table D.3: Descriptive Statistics

\begin{tabular}{|c|c|c|c|c|c|}
\hline & Obs. & Mean & Std.Dev & Min. & Max. \\
\hline \multicolumn{6}{|l|}{ Child Labor, Agricultural Survey, 1929} \\
\hline Share of French agricultural workers below age 15 in the agricultural sector & 87 & 0.01 & 0.01 & 0.00 & 0.07 \\
\hline Share of French agricultural workers below age 15 among agricultural workers & 89 & 0.01 & 0.01 & 0.00 & 0.06 \\
\hline Share of French agricultural workers below age 15 among agricultural workers below age 15 & 89 & 1.00 & 0.00 & 1.00 & 1 \\
\hline Share of French agricultural workers below age 15 among agricultural workers above age 15 & 89 & 0.07 & 0.05 & 0.01 & 0.26 \\
\hline \multicolumn{6}{|l|}{ Voters in 1839} \\
\hline Share of Electors in Departmental Population & 82 & 0.01 & 0.00 & 0.00 & 0.01 \\
\hline Share of Landowners Among Electors & 67 & 0.56 & 0.09 & 0.28 & 0.72 \\
\hline Share of Businessmen Among Electors & 67 & 0.24 & 0.09 & 0.10 & 0.60 \\
\hline Share of Professionals Among Electors & 67 & 0.11 & 0.04 & 0.04 & 0.24 \\
\hline Share of Civil Servants Among Electors & 67 & 0.09 & 0.04 & 0.02 & 0.18 \\
\hline \multicolumn{6}{|l|}{ Share of Illiterate Conscripts } \\
\hline Share of Illiterate Conscripts 1840 s & 85 & 0.37 & 0.18 & 0.03 & 0.71 \\
\hline Share of Illiterate Conscripts $1850 \mathrm{~s}$ & 85 & 0.32 & 0.17 & 0.03 & 0.68 \\
\hline Share of Illiterate Conscripts $1860 \mathrm{~s}$ & 88 & 0.23 & 0.14 & 0.02 & 0.54 \\
\hline Share of Illiterate Conscripts 1870 s & 89 & 0.16 & 0.10 & 0.01 & 0.47 \\
\hline Share of Illiterate Conscripts 1880s & 86 & 0.11 & 0.08 & 0.01 & 0.38 \\
\hline Share of Illiterate Conscripts 1890s & 86 & 0.05 & 0.04 & 0.01 & 0.20 \\
\hline Share of Illiterate Conscripts 1900s & 86 & 0.03 & 0.03 & 0.00 & 0.15 \\
\hline Share of Illiterate Conscripts 1910s & 86 & 0.03 & 0.02 & 0.00 & 0.09 \\
\hline Share of Illiterate Conscripts 1930s & 89 & 0.05 & 0.01 & 0.03 & 0.08 \\
\hline \multicolumn{6}{|l|}{ Price of Wheat, 1797-1800 } \\
\hline Wheat Price, $1797-1800$ & 337 & 18.28 & 4.92 & 9.08 & 38.48 \\
\hline \multicolumn{6}{|l|}{ Share of Church Land Sold in Department } \\
\hline Share of Church Land Sold in Department & 67 & 0.025 & 0.013 & 0.00 & 0.156 \\
\hline
\end{tabular}


Table D.4: Descriptive Statistics

Average Temperature in Summers 1788-1800

Average Temperature in Summer 1788

Average Temperature in Summer 1789

Average Temperature in Summer 1790

Average Temperature in Summer 1791

Average Temperature in Summer 1792

Average Temperature in Summer 1793

Average Temperature in Summer 1794

Average Temperature in Summer 1795

Average Temperature in Summer 1796

Average Temperature in Summer 1797

Average Temperature in Summer 1798

Average Temperature in Summer 1799

Average Temperature in Summer 1800

Squared Standardized Deviation of Summer Temperature

Squared Standardized Deviation of Summer Temperature 1788 (1763-1787)

Squared Standardized Deviation of Summer Temperature 1789 (1764-1788)

Squared Standardized Deviation of Summer Temperature 1790 (1765-1789)

Squared Standardized Deviation of Summer Temperature 1791 (1766-1790)

Squared Standardized Deviation of Summer Temperature 1792 (1767-1791)

Squared Standardized Deviation of Summer Temperature 1793 (1768-1792)

Squared Standardized Deviation of Summer Temperature 1794 (1769-1793)

Squared Standardized Deviation of Summer Temperature 1795 (1770-1794)

Squared Standardized Deviation of Summer Temperature 1796 (1771-1795)

Squared Standardized Deviation of Summer Temperature 1797 (1772-1796)

Squared Standardized Deviation of Summer Temperature 1798 (1773-1797)

Squared Standardized Deviation of Summer Temperature 1799 (1774-1798)

Squared Standardized Deviation of Summer Temperature 1800 (1775-1799)

Absolute Standardized Deviation of Summer Temperature

Absolute Standardized Deviation of Summer Temperature 1788 (1763-1787)

Absolute Standardized Deviation of Summer Temperature 1789 (1764-1788)

Absolute Standardized Deviation of Summer Temperature 1790 (1765-1789)

Absolute Standardized Deviation of Summer Temperature 1791 (1766-1790)

Absolute Standardized Deviation of Summer Temperature 1792 (1767-1791)

Absolute Standardized Deviation of Summer Temperature 1793 (1768-1792)

Absolute Standardized Deviation of Summer Temperature 1794 (1769-1793)

Absolute Standardized Deviation of Summer Temperature 1795 (1770-1794)

Absolute Standardized Deviation of Summer Temperature 1796 (1771-1795)

Absolute Standardized Deviation of Summer Temperature 1797 (1772-1796)

Absolute Standardized Deviation of Summer Temperature 1798 (1773-1797)

Absolute Standardized Deviation of Summer Temperature 1799 (1774-1798)

Absolute Standardized Deviation of Summer Temperature 1800 (1775-1799)

\begin{tabular}{ccccc} 
Obs. & Mean & Std.Dev & Min. & Max. \\
88 & 18.48 & 1.38 & 14.18 & 22.31 \\
88 & 17.37 & 1.3 & 12.66 & 20.87 \\
88 & 18.09 & 1.43 & 14.03 & 22.04 \\
88 & 18.16 & 1.37 & 13.93 & 21.95 \\
88 & 17.97 & 1.36 & 13.69 & 21.82 \\
88 & 18.49 & 1.44 & 14.72 & 22.53 \\
88 & 18.38 & 1.33 & 14.16 & 22.13 \\
88 & 17.39 & 1.38 & 13.23 & 21.34 \\
88 & 17.37 & 1.37 & 13.21 & 21.34 \\
88 & 17.84 & 1.41 & 13.58 & 21.93 \\
88 & 18.48 & 1.37 & 13.83 & 22.13 \\
88 & 16.82 & 1.32 & 12.88 & 20.77 \\
88 & 17.86 & 1.42 & 13.39 & 21.57 \\
& & & & \\
86 & 0.82 & 0.53 & 0.02 & 2.27 \\
86 & 1.34 & 1.00 & 0.00 & 3.73 \\
86 & 0.27 & 0.29 & 0.00 & 1.25 \\
86 & 0.15 & 0.15 & 0.00 & 0.51 \\
86 & 0.05 & 0.07 & 0.00 & 0.30 \\
86 & 0.97 & 1.17 & 0.00 & 5.45 \\
86 & 0.43 & 0.44 & 0.00 & 1.61 \\
86 & 1.35 & 0.47 & 0.32 & 2.17 \\
86 & 1.48 & 0.49 & 0.31 & 2.28 \\
86 & 0.32 & 0.34 & 0.00 & 1.35 \\
86 & 0.48 & 0.19 & 0.00 & 0.96 \\
86 & 5.25 & 1.64 & 1.68 & 9.31 \\
86 & 0.26 & 0.32 & 0.00 & 1.29 \\
& & & & \\
86 & 0.85 & 0.32 & 0.13 & 1.51 \\
86 & 1.05 & 0.48 & 0.01 & 1.93 \\
86 & 0.44 & 0.28 & 0.00 & 1.12 \\
86 & 0.33 & 0.21 & 0.02 & 0.72 \\
86 & 0.19 & 0.14 & 0.01 & 0.55 \\
86 & 0.81 & 0.56 & 0.01 & 2.33 \\
86 & 0.54 & 0.37 & 0.01 & 1.27 \\
86 & 1.14 & 0.22 & 0.56 & 1.47 \\
86 & 1.20 & 0.22 & 0.56 & 1.51 \\
86 & 0.47 & 0.31 & 0.01 & 1.16 \\
86 & 0.67 & 0.17 & 0.02 & 0.98 \\
86 & 2.26 & 0.36 & 1.30 & 3.05 \\
86 & 0.41 & 0.31 & 0.01 & 1.13 \\
\hline & & & &
\end{tabular}


Table D.5: Do Temperature Deviations Influence Local Food Prices and Local Violence?

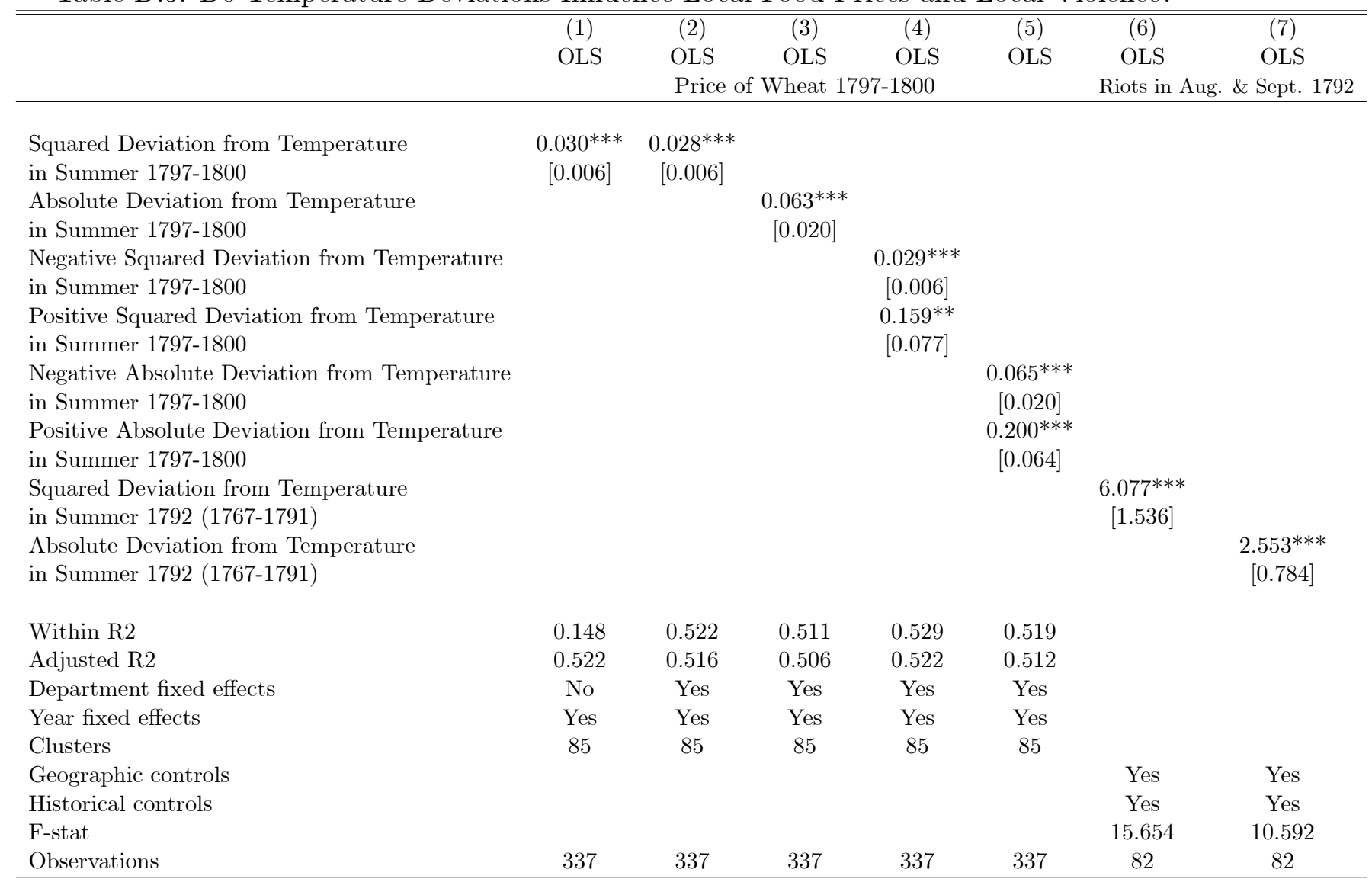

Note: This table reports the effect of the absolute and squared deviation from standardized temperature in summer 1797-1800 on the price of wheat in OLS regressions with département- and year-fixed effects in 1797-1800 period (columns 1-4) and in the summer of 1792 on the number of riots in August and September 1792 accounting for geographic and historical controls (columns 5-6). All the dependent variables are in logarithm. Robust standard errors are reported in brackets. *** significant at the $1 \%$ level, ** at the $5 \%$ level, * at the $10 \%$ level. 


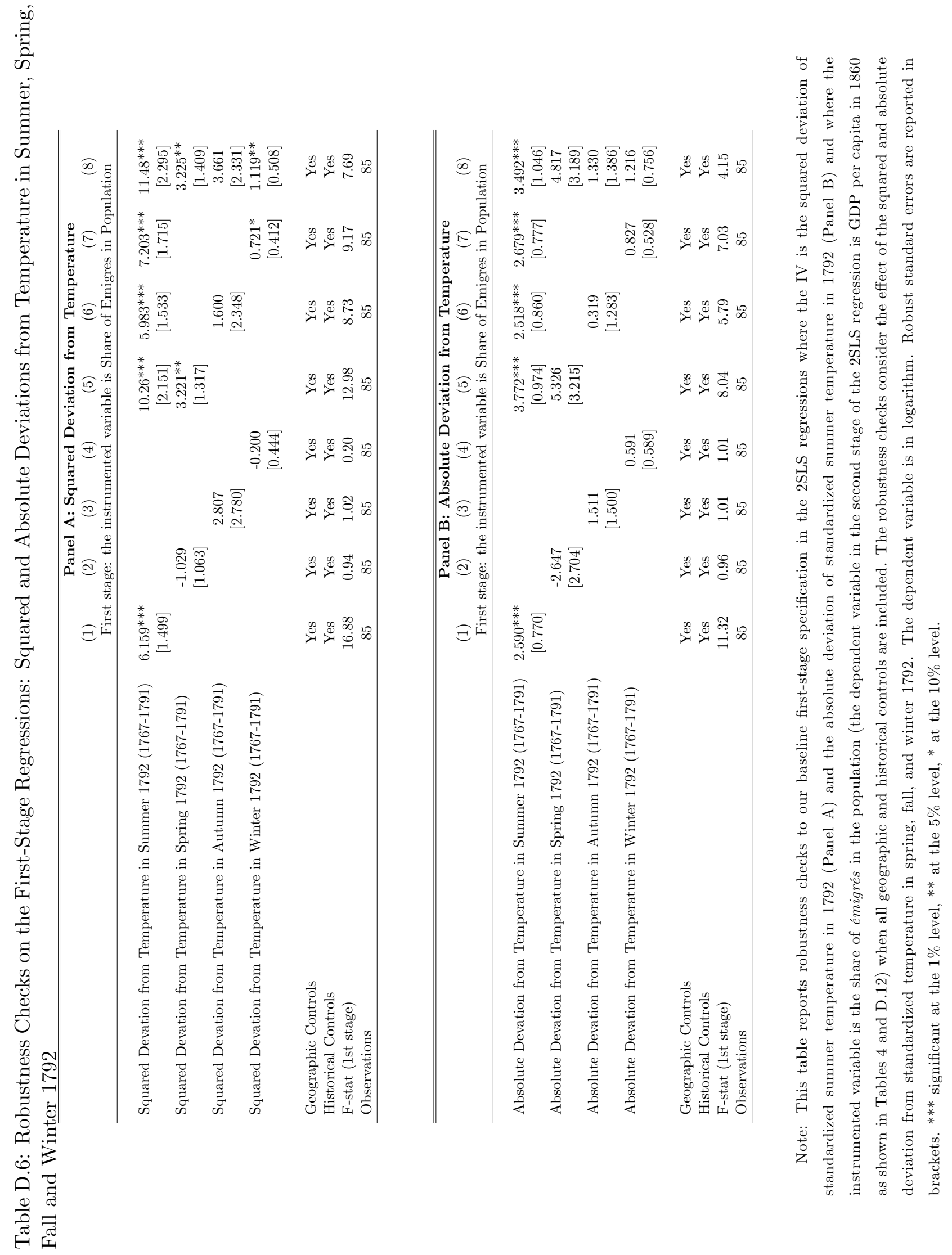


Table D.7: Robustness Checks: Deviations from Temperature in Summer 1792 on GDP per Capita 1860: Summers 1788-1800

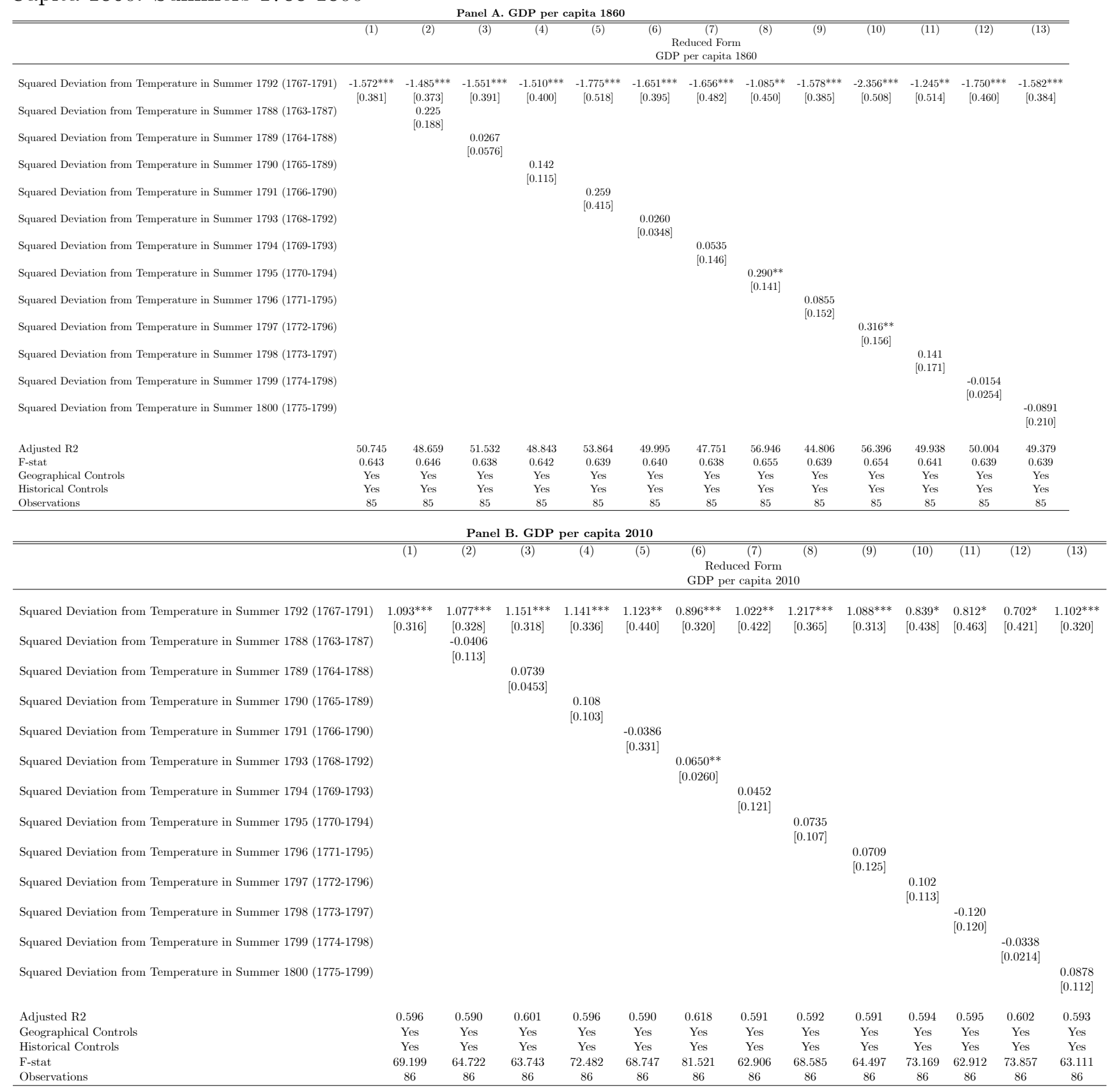

Note: This table reports reduced-form regressions that assess the effect of the squared deviation from standardized temperature in the summer of 1792 on GDP per capita in 1860 (Panel A) and GDP per capita in 2010 (Panel B), accounting for the squared deviation standardized temperature in the summers over the 1788-1800 period. It shows that only the squared deviation from standardized temperature in 1792 has a negative impact on GDP per capita in 1860 and a positive impact on GDP per capita in 2010. The dependent variables are in logarithm. Robust standard errors are reported in brackets. ${ }^{* * *}$ significant at the $1 \%$ level, ** at the $5 \%$ level, * at the $10 \%$ level. 
Table D.8: First-Stage Regressions: Squared and Absolute Deviations from Temperature and Rainfall in Summer 1792

\begin{tabular}{|c|c|c|c|c|}
\hline \multirow{2}{*}{\multicolumn{5}{|c|}{$\begin{array}{lcc} & (1) & (2) \\
\text { First stage: the instrumented variable is the Share of Emigres }\end{array}$}} \\
\hline & & & & \\
\hline Squared Deviation from Temperature in Summer 1792 (1767-1791) & $\begin{array}{l}6.159^{* * *} \\
{[1.499]}\end{array}$ & $\begin{array}{c}6.458^{* * *} \\
{[1.524]}\end{array}$ & & \\
\hline Squared Deviation from Rainfall in Summer 1792 (1767-1791) & & $\begin{array}{l}0.980^{*} \\
{[0.525]}\end{array}$ & & \\
\hline Absolute Deviation from Temperature in Summer 1792 (1767-1791) & & & $\begin{array}{c}2.590^{* * *} \\
{[0.770]}\end{array}$ & $\begin{array}{c}2.840^{* * *} \\
{[0.828]}\end{array}$ \\
\hline Absolute Deviation from Rainfall in Summer 1792 (1767-1791) & & & & $\begin{array}{c}0.617 \\
{[0.420]}\end{array}$ \\
\hline Geographic controls & Yes & Yes & Yes & Yes \\
\hline Historical controls & Yes & Yes & Yes & Yes \\
\hline F-stat (1st stage) & 85 & 85 & 85 & 85 \\
\hline Observations & 16.862 & 28.958 & 13.190 & 18.876 \\
\hline
\end{tabular}

Note: This table reports robustness checks to our baseline first-stage specification in the 2SLS regressions where the IV is the squared and absolute deviation of standardized summer temperature in 1792 and where the instrumented variable is the share of émigrés in the population (the dependent variable in the second stage of the 2SLS regression is GDP per capita in 1860 as shown in Table 3). The robustness checks consider the effect of the squared and absolute deviation from standardized rainfall in the summer of 1792 . All the dependent variables are in logarithm. Robust standard errors are reported in brackets. *** significant at the $1 \%$ level, $* *$ at the $5 \%$ level, * at the $10 \%$ level. 
Table D.9: First-Stage Regressions: The Impact of Summer Deviations from Temperature in Summer 1792 on Emigration, Accounting from Spatial Correlation

\begin{tabular}{|c|c|c|c|}
\hline & $\begin{array}{c}(1) \\
\text { OLS }\end{array}$ & $\begin{array}{l}(2) \\
\text { OLS }\end{array}$ & $\begin{array}{c}\text { OLS } \\
\text { OLS }\end{array}$ \\
\hline & \multicolumn{3}{|c|}{ Share of Emigres } \\
\hline $\begin{array}{l}\text { Squared Deviation from Temperature } \\
\text { in Summer } 1792(1767-1791)\end{array}$ & 4.336 & 5.950 & 6.216 \\
\hline White Robust Standard Errors & {$[1.140]^{* * *}$} & {$[1.445]^{* * *}$} & {$[1.481]^{* * *}$} \\
\hline Spatial std. errors, $25 \mathrm{~km}$ & {$[1.038]^{* * *}$} & {$[1.278]^{* * *}$} & {$[1.332]^{* * *}$} \\
\hline Spatial std. errors, 50 km & {$[1.043]^{* * *}$} & {$[1.279]^{* * *}$} & {$[1.333]^{* * *}$} \\
\hline Spatial std. errors, $100 \mathrm{~km}$ & {$[1.141]^{* * *}$} & {$[1.278]^{* * *}$} & {$[1.319]^{* * *}$} \\
\hline Spatial std. errors, $200 \mathrm{~km}$ & {$[1.449]^{* * *}$} & {$[1.185]^{* * *}$} & {$[1.177]^{* * *}$} \\
\hline Spatial std. errors, $300 \mathrm{~km}$ & {$[1.634]^{* * *}$} & {$[1.154]^{* * *}$} & {$[1.102]^{* * *}$} \\
\hline Spatial std. errors, $400 \mathrm{~km}$ & {$[1.732]^{* *}$} & {$[1.185]^{* * *}$} & {$[1.071]^{* * *}$} \\
\hline Spatial std. errors, $500 \mathrm{~km}$ & {$[1.761]^{* *}$} & {$[1.229]^{* * *}$} & {$[1.069]^{* * *}$} \\
\hline Geographic controls & No & Yes & Yes \\
\hline Historical controls & No & No & Yes \\
\hline Observations & 86 & 86 & 86 \\
\hline
\end{tabular}

Note: This table reports White robust standard errors and spatial Conley (1999) standard errors for the first stage of our 2SLS regressions between our IV, the squared deviation from standardized temperature in the summer of 1792 , and the instrumented variable, the share of émigrés in the population. The dependent variable is in logarithm. Robust standard errors are reported in brackets. *** significant at the $1 \%$ level, ** at the $5 \%$ level, * at the $10 \%$ level. 
Table D.10: Robustness Checks: Baseline Deviations from Temperature in Summer 1792 and GDP per capita 1860 and 2010

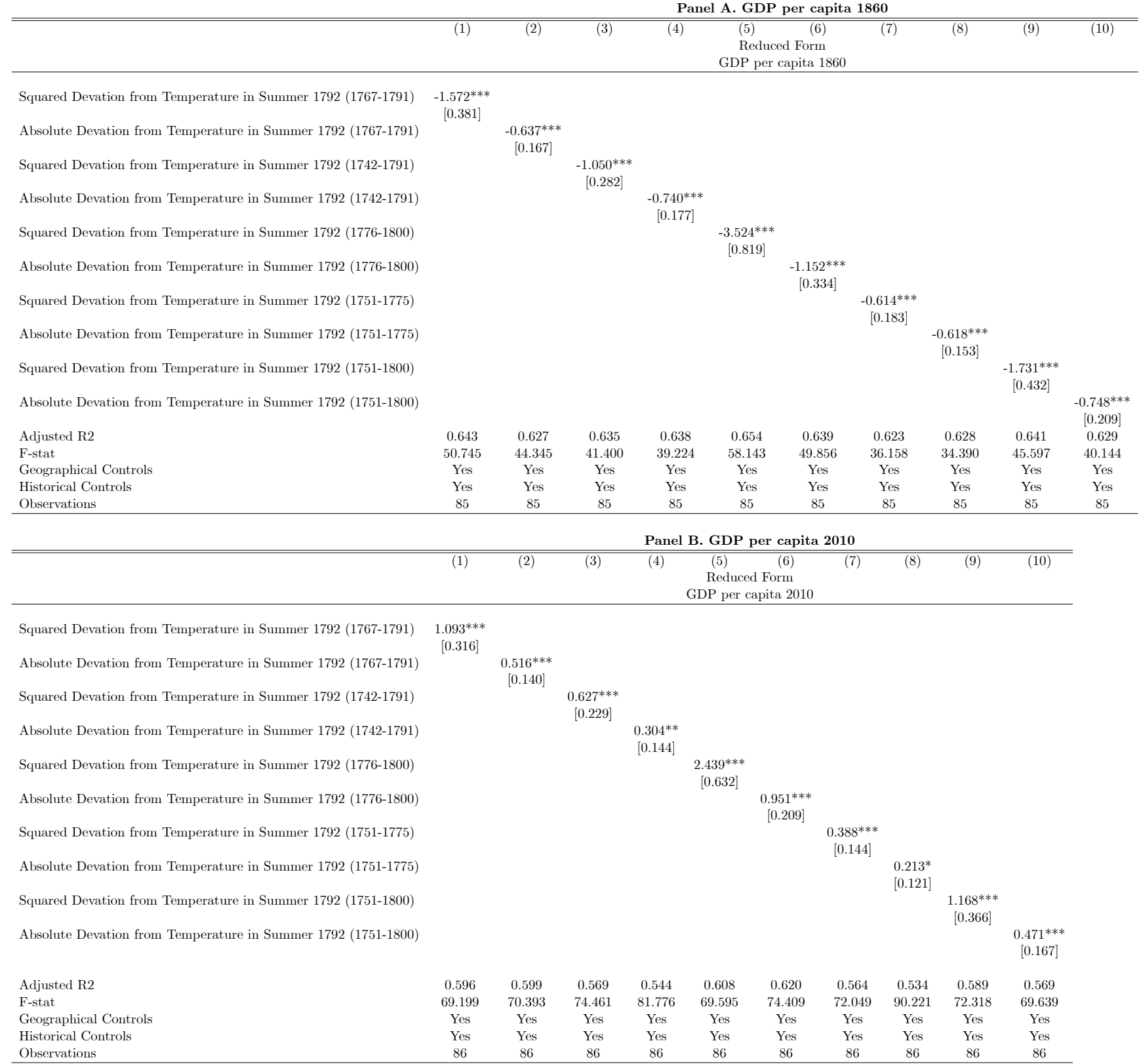

Note: This table reports reduced-form regressions that assess the effect of our IVs, the squared and absolute deviations from standardized temperature in the summer of 1792, on GDP per capita in 1860 (Panel A) and GDP per capita in 2010 (Panel B), where we consider baseline periods other than the 25 years preceding 1792. In all specifications, the squared deviation from standardized temperature in 1792 has a negative impact on GDP per capita in 1860 and a positive impact on GDP per capita in 2010. The dependent variables are in logarithm. Robust standard errors are reported in brackets. *** significant at the $1 \%$ level, ** at the $5 \%$ level, * at the $10 \%$ level. 
Table D.11: Summer Temperature Shock 1792 and Emigration: Falsification Tests

Panel A. Violence before and after 1789-1815.

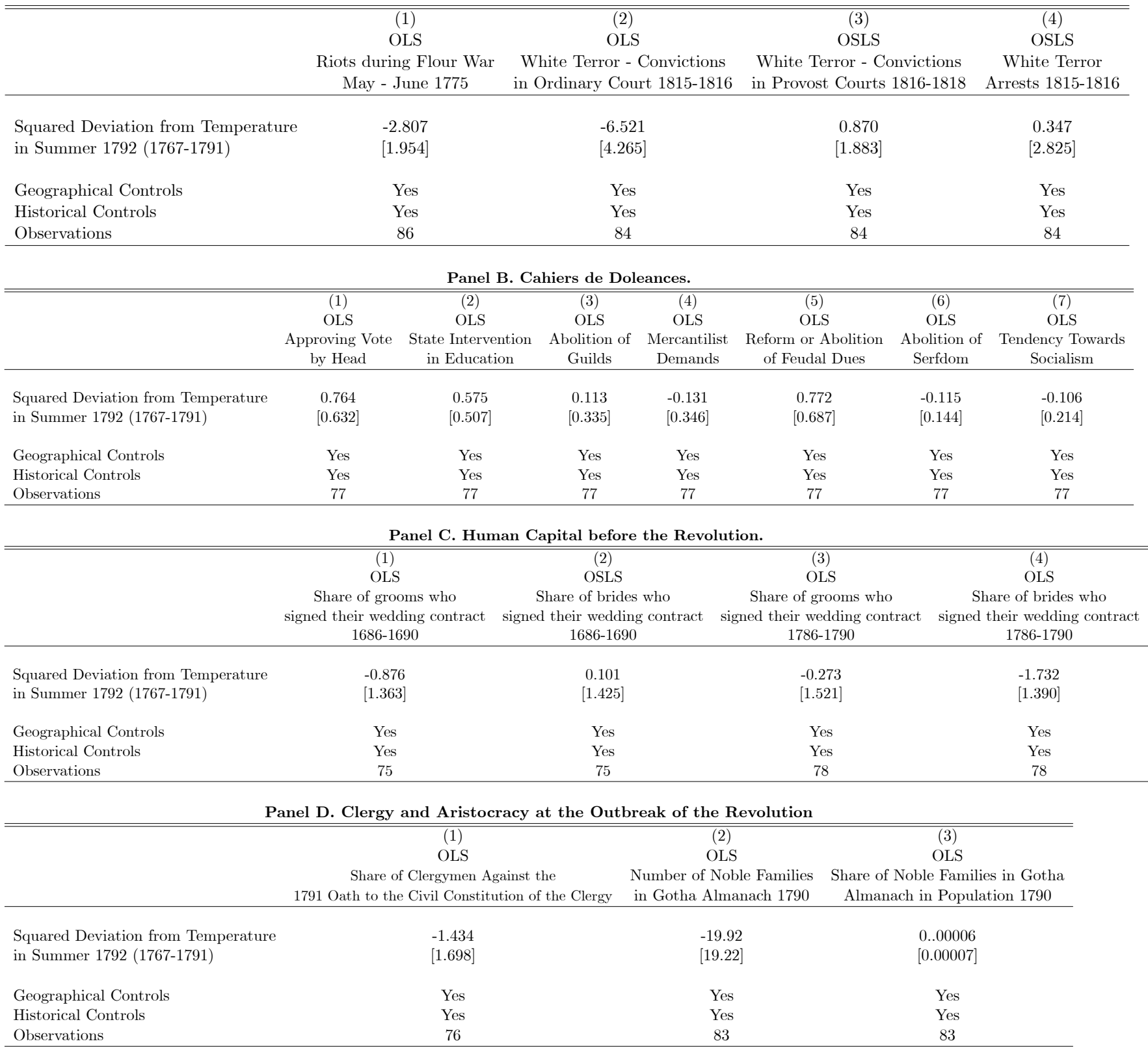

Note: This table reports reduced-form regressions between our IV, the squared deviation from standardized temperature in the summer of 1792 and several variables which could potentially be endogenous to economic growth, and which could bias our estimates if they were correlated with our IV. These are variables pertaining to violence before 1789 and after 1815, demands from the cahiers de doléances (Panel B), measures of human capital before the Revolution (Panel C), and measures for the presence of the local clergy and aristocracy at the outbreak of the Revolution (Panel D). All the dependent variables are in logarithm. Robust standard errors are reported in brackets. ${ }^{* *}$ significant at the $1 \%$ level, ${ }^{* *}$ at the $5 \%$ level, ${ }^{*}$ at the $10 \%$ level. 
Table D.12: Emigrés and GDP per capita (IV: Absolute Deviation of Temperature in Summer 1792)

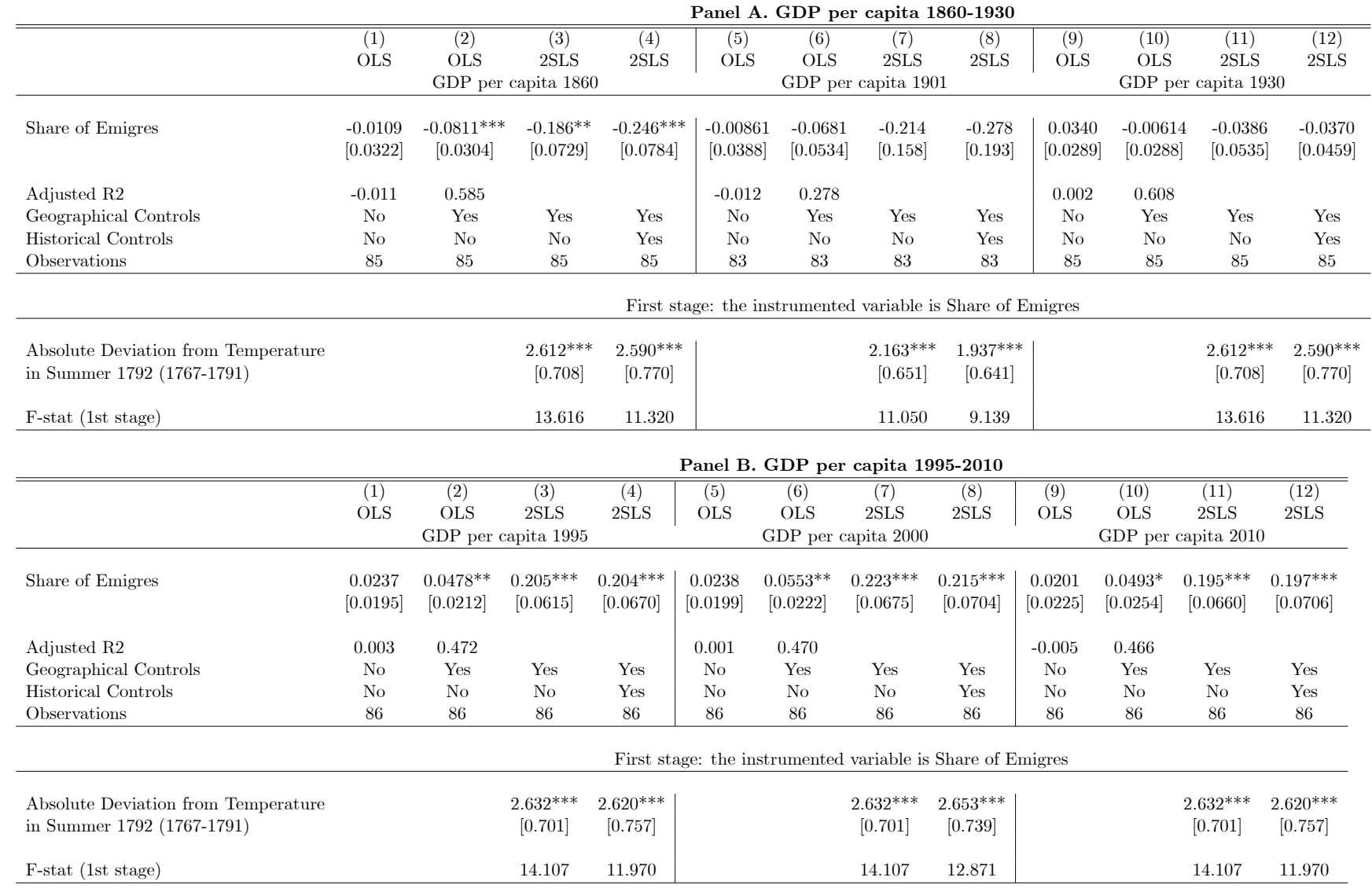

Note: This table reports the effect of the share of émigrés in the population on the logarithm of GDP per capita in OLS and 2SLS regressions in 1860, 1901, and 1930 (Panel A) and in 1995, 2000, and 2010 (Panel B). The IV in the first stage of the 2SLS regressions is the absolute standardized deviation from temperature in the summer of 1792. All the dependent variables are in logarithm. Robust standard errors are reported in brackets. ${ }^{* * *}$ significant at the $1 \%$ level, ${ }^{* *}$ at the $5 \%$ level, ${ }^{*}$ at the $10 \%$ level. 
Table D.13: The Effect of the Social Categories of Emigrés on GDP per capita in 1860 and 2010

\begin{tabular}{|c|c|c|c|c|}
\hline & $\begin{array}{c}(1) \\
2 \text { SLS }\end{array}$ & $\begin{array}{c}(2) \\
\text { 2SLS }\end{array}$ & $\begin{array}{c}(3) \\
\text { 2SLS }\end{array}$ & $\begin{array}{c}(4) \\
2 \text { SLS }\end{array}$ \\
\hline $\begin{array}{l}\text { Share of Rich Emigres } \\
\text { (Clergy, Nobility, Upper Middle Class) } \\
\text { Share of Poor Emigres } \\
\text { (Lower Middle Class, Workers, Peasants) }\end{array}$ & $\begin{array}{c}-0.293^{* *} \\
{[0.116]}\end{array}$ & $\begin{array}{c}-0.0824^{* * *} \\
{[0.0313]}\end{array}$ & $\begin{array}{l}0.205^{* *} \\
{[0.0885]}\end{array}$ & $\begin{array}{c}0.0605^{* *} \\
{[0.0244]}\end{array}$ \\
\hline $\begin{array}{l}\text { Geographic Controls } \\
\text { Historical Controls } \\
\text { Observations }\end{array}$ & $\begin{array}{l}\text { Yes } \\
\text { Yes } \\
68\end{array}$ & $\begin{array}{l}\text { Yes } \\
\text { Yes } \\
68\end{array}$ & $\begin{array}{l}\text { Yes } \\
\text { Yes } \\
69\end{array}$ & $\begin{array}{c}\text { Yes } \\
69\end{array}$ \\
\hline
\end{tabular}

First stage: the instrumented variable is

Share of Rich Emigres Share of Poor Emigres Share of Rich Emigres Share of Poor Emigres

\begin{tabular}{|c|c|c|c|c|}
\hline $\begin{array}{l}\text { Squared Deviation from Temperature } \\
\text { in Summer } 1792(1767-1791)\end{array}$ & $\begin{array}{c}4.342^{* * *} \\
{[1.247]}\end{array}$ & $\begin{array}{c}15.46^{* * *} \\
{[3.840]}\end{array}$ & $\begin{array}{c}4.638^{* * *} \\
{[1.293]}\end{array}$ & $\begin{array}{c}15.70^{* * *} \\
{[3.760]}\end{array}$ \\
\hline F-stat (1st stage) & 12.130 & 16.207 & 12.862 & 17.422 \\
\hline
\end{tabular}

Note: This table reports the effect of the different categories of émigrés in the population on GDP per capita in 1860 and 2010 in 2SLS regressions. All the dependent variables are in logarithm. The IV in the first stage of the 2SLS regressions is the squared standardized deviation from temperature in the summer of 1792 . Robust standard errors are reported in brackets. ${ }^{* * *}$ significant at the $1 \%$ level, ${ }^{* *}$ at the $5 \%$ level, ${ }^{*}$ at the $10 \%$ level. 
Table D.14: Emigrés and Population Size, 1801-2010

\begin{tabular}{|c|c|c|c|c|c|c|c|c|c|c|c|c|}
\hline & $\begin{array}{c}(1) \\
2 \text { SLS }\end{array}$ & $\begin{array}{c}(2) \\
2 S L S\end{array}$ & $\begin{array}{c}(3) \\
2 \text { SLS }\end{array}$ & $\begin{array}{c}(4) \\
2 \text { SLS }\end{array}$ & $\begin{array}{c}(5) \\
2 \mathrm{SLS}\end{array}$ & $\begin{array}{c}(6) \\
\text { 2SLS }\end{array}$ & $\begin{array}{c}(7) \\
\text { 2SLS }\end{array}$ & $\begin{array}{c}(8) \\
2 S L S\end{array}$ & $\begin{array}{c}(9) \\
\text { 2SLS }\end{array}$ & $\begin{array}{l}(10) \\
\text { 2SLS }\end{array}$ & $\begin{array}{l}(11) \\
\text { 2SLS }\end{array}$ & \\
\hline & \multicolumn{11}{|c|}{ Population of Département } & \\
\hline & 1801 & 1821 & 1841 & 1861 & 1881 & 1901 & 1921 & 1968 & 1982 & 1999 & 2010 & \\
\hline Share of Emigres & $\begin{array}{c}0.0600 \\
{[0.0927]}\end{array}$ & $\begin{array}{c}0.0778 \\
{[0.0956]}\end{array}$ & $\begin{array}{c}0.0975 \\
{[0.0989]}\end{array}$ & $\begin{array}{l}0.0630 \\
{[0.107]}\end{array}$ & $\begin{array}{l}-0.139 \\
{[0.148]}\end{array}$ & $\begin{array}{r}-0.0447 \\
{[0.165]}\end{array}$ & $\begin{array}{c}0.202 \\
{[0.148]}\end{array}$ & $\begin{array}{c}0.398 * * \\
{[0.182]}\end{array}$ & $\begin{array}{c}0.492^{* *} \\
{[0.195]}\end{array}$ & $\begin{array}{c}0.554^{* * *} \\
{[0.204]}\end{array}$ & $\begin{array}{c}0.594^{* * *} \\
{[0.208]}\end{array}$ & \\
\hline $\begin{array}{l}\text { Geographic controls } \\
\text { Historical controls } \\
\text { Observations }\end{array}$ & $\begin{array}{l}\text { Yes } \\
\text { Yes } \\
84 \\
\end{array}$ & $\begin{array}{l}\text { Yes } \\
\text { Yes } \\
84 \\
\end{array}$ & $\begin{array}{l}\text { Yes } \\
\text { Yes } \\
84 \\
\end{array}$ & $\begin{array}{l}\text { Yes } \\
\text { Yes } \\
86 \\
\end{array}$ & $\begin{array}{l}\text { Yes } \\
\text { Yes } \\
84 \\
\end{array}$ & $\begin{array}{l}\text { Yes } \\
\text { Yes } \\
84 \\
\end{array}$ & $\begin{array}{l}\text { Yes } \\
\text { Yes } \\
86 \\
\end{array}$ & $\begin{array}{l}\text { Yes } \\
\text { Yes } \\
86 \\
\end{array}$ & $\begin{array}{l}\text { Yes } \\
\text { Yes } \\
86 \\
\end{array}$ & $\begin{array}{l}\text { Yes } \\
\text { Yes } \\
86 \\
\end{array}$ & $\begin{array}{l}\text { Yes } \\
\text { Yes } \\
86 \\
\end{array}$ & \\
\hline Observations & \multicolumn{11}{|c|}{ First stage: the instrumented variable is Share of Emigres } & \\
\hline $\begin{array}{l}\text { Squared Deviation from Temperature } \\
\text { in Summer } 1792 \text { (1767-1791) }\end{array}$ & $\begin{array}{c}6.834^{* * *} \\
{[1.547]}\end{array}$ & $\begin{array}{c}6.834^{* * *} \\
{[1.547]}\end{array}$ & $\begin{array}{c}6.834^{* * *} \\
{[1.547]}\end{array}$ & $\begin{array}{c}6.216^{* * *} \\
{[1.487]}\end{array}$ & $\begin{array}{c}5.131^{* * *} \\
{[1.221]}\end{array}$ & $\begin{array}{c}5.131^{* * *} \\
{[1.221]}\end{array}$ & $\begin{array}{c}6.216^{* * *} \\
{[1.487]}\end{array}$ & $\begin{array}{c}6.216^{* * *} \\
{[1.487]}\end{array}$ & $\begin{array}{c}6.216^{* * *} \\
{[1.487]}\end{array}$ & $\begin{array}{c}6.216^{* * *} \\
{[1.487]}\end{array}$ & $\begin{array}{c}6.216^{* * *} \\
{[1.487]}\end{array}$ & \\
\hline \multirow[t]{6}{*}{ F-stat (1st stage) } & 19.515 & 19.515 & 19.515 & 17.476 & 17.657 & 17.657 & 17.476 & 17.476 & 17.476 & 17.476 & 17.476 & \\
\hline & \multicolumn{12}{|c|}{ Panel B. Population of Chef-Lieu of Département, 1806-2006 } \\
\hline & (1) & (2) & $\begin{array}{l}(3) \\
\end{array}$ & (4) & $(5)$ & (6) & (7) & $(8)$ & (9) & (10) & (11) & (12) \\
\hline & 2SLS & 2SLS & 2SLS & 2SLS & 2SLS & 2SLS & 2SLS & 2SLS & 2SLS & 2SLS & 2SLS & 2SLS \\
\hline & \multicolumn{12}{|c|}{ Population of Chef-Lieu of Département } \\
\hline & 1806 & 1821 & 1841 & 1861 & 1881 & 1901 & 1921 & 1946 & 1968 & 1982 & 1999 & 2006 \\
\hline Share of Emigres & $\begin{array}{l}-0.188 \\
{[0.273]}\end{array}$ & $\begin{array}{c}-0.0795 \\
{[0.240]}\end{array}$ & $\begin{array}{l}-0.186 \\
{[0.219]}\end{array}$ & $\begin{array}{l}0.0696 \\
{[0.270]}\end{array}$ & $\begin{array}{c}0.143 \\
{[0.298]}\end{array}$ & $\begin{array}{c}0.517 \\
{[0.475]}\end{array}$ & $\begin{array}{c}0.585 \\
{[0.508]}\end{array}$ & $\begin{array}{c}0.700 \\
{[0.518]}\end{array}$ & $\begin{array}{c}0.802 \\
{[0.498]}\end{array}$ & $\begin{array}{l}0.867^{*} \\
{[0.491]}\end{array}$ & $\begin{array}{l}0.942^{*} \\
{[0.492]}\end{array}$ & $\begin{array}{c}0.972^{* *} \\
{[0.482]}\end{array}$ \\
\hline Geographic controls & Yes & Yes & Yes & Yes & Yes & Yes & Yes & Yes & Yes & Yes & Yes & Yes \\
\hline Historical controls & Yes & Yes & Yes & Yes & Yes & Yes & Yes & Yes & Yes & Yes & Yes & Yes \\
\hline \multirow[t]{2}{*}{ Observations } & 86 & 86 & 84 & 85 & 86 & 86 & 86 & 86 & 86 & 86 & 86 & 86 \\
\hline & \multicolumn{12}{|c|}{ First stage: the instrumented variable is Share of Emigres } \\
\hline $\begin{array}{l}\text { Squared Deviation from Temperature } \\
\text { in Summer } 1792 \text { (1767-1791) }\end{array}$ & $\begin{array}{c}6.216^{* * *} \\
{[1.487]}\end{array}$ & $\begin{array}{c}6.216^{* * *} \\
{[1.487]}\end{array}$ & $\begin{array}{c}6.834^{* * *} \\
{[1.547]}\end{array}$ & $\begin{array}{c}6.209^{* * *} \\
{[1.484]}\end{array}$ & $\begin{array}{c}6.216^{* * *} \\
{[1.487]}\end{array}$ & $\begin{array}{c}6.216^{* * *} \\
{[1.487]}\end{array}$ & $\begin{array}{c}6.216^{* * *} \\
{[1.487]}\end{array}$ & $\begin{array}{c}6.216^{* * *} \\
{[1.487]}\end{array}$ & $\begin{array}{c}6.216^{* * *} \\
{[1.487]}\end{array}$ & $\begin{array}{c}6.216^{* * *} \\
{[1.487]}\end{array}$ & $\begin{array}{c}6.216^{* * *} \\
{[1.487]}\end{array}$ & $\begin{array}{c}6.216^{* * *} \\
{[1.487]}\end{array}$ \\
\hline F-stat (1st stage) & 17.476 & 17.476 & 19.515 & 17.514 & 17.476 & 17.476 & 17.476 & 17.476 & 17.476 & 17.476 & 17.476 & 17.476 \\
\hline
\end{tabular}

Note: This table reports the effect of the share of émigrés in the population on the population in each département (Panel A) and in the chef-lieu (i.e., main administrative center) of each département over the 1801-2010 period. All the dependent variables are in logarithm. The IV in the first stage of the 2SLS regressions is the squared standardized deviation from temperature in the summer of 1792. Robust standard errors are reported in brackets. ${ }^{* * *}$ significant at the $1 \%$ level, ${ }^{* *}$ at the $5 \%$ level, ${ }^{*}$ at the $10 \%$ level. 
Table D.15: Emigrés and Financial Development: Savings Banks' Loans and Contracts Sealed by Notaries

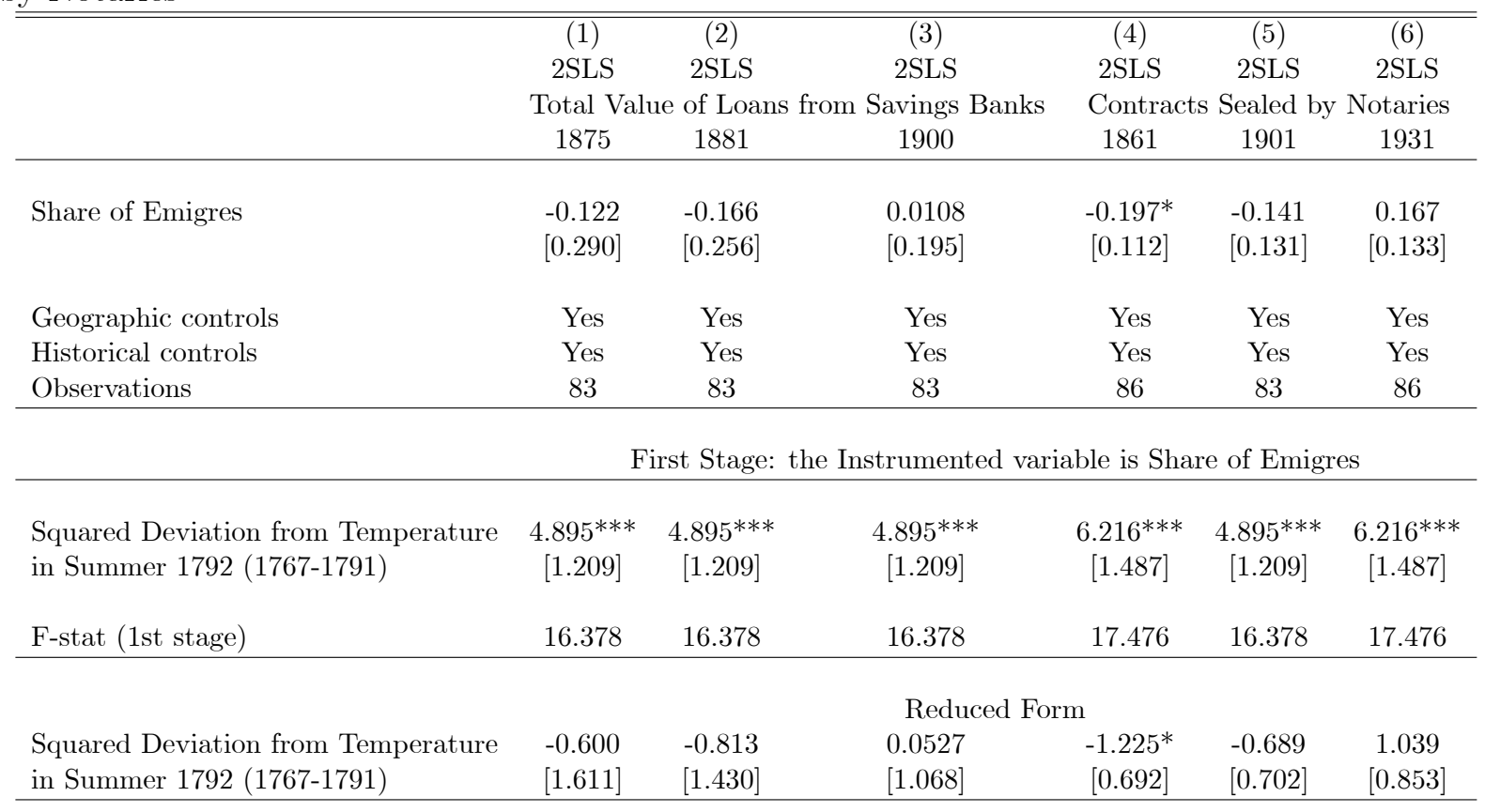

Note: This table reports the effect of the share of émigrés in the population on the amount of loans given by savings banks (columns 1-3) and the number of contracts sealed by notaries (columns 4-6) where the IV is the squared standardized deviation from summer temperature in 1792. All the dependent variables are in logarithm. Robust standard errors are reported in brackets. *** significant at the $1 \%$ level, ** at the $5 \%$ level, * at the $10 \%$ level. 
Table D.16: Emigrés and Civil Servants in the Workforce in the 19th century

\begin{tabular}{|c|c|c|c|}
\hline & $\begin{array}{c}(1) \\
\text { 2SLS }\end{array}$ & $\begin{array}{c}(2) \\
\text { 2SLS }\end{array}$ & $\begin{array}{c}(3) \\
2 S L S\end{array}$ \\
\hline & \multicolumn{3}{|c|}{ Share of Civil Servants in Workforce } \\
\hline & 1851 & 1866 & 1881 \\
\hline Share of Emigres & $\begin{array}{c}0.814^{* * *} \\
{[0.217]}\end{array}$ & $\begin{array}{c}0.363^{* *} \\
{[0.180]}\end{array}$ & $\begin{array}{l}0.150 \\
{[0.262]}\end{array}$ \\
\hline Geographic controls & Yes & Yes & Yes \\
\hline Historical controls & Yes & Yes & Yes \\
\hline Observations & 84 & 86 & 83 \\
\hline \multicolumn{4}{|c|}{ First stage: the instrumented variable is Share of Emigres } \\
\hline $\begin{array}{l}\text { Squared Deviation from Temperature } \\
\text { in Summer } 1792 \text { (1767-1791) }\end{array}$ & $\begin{array}{c}6.834^{* * *} \\
{[1.547]}\end{array}$ & $\begin{array}{c}6.216^{* * *} \\
{[1.487]}\end{array}$ & $\begin{array}{c}4.895^{* * *} \\
{[1.209]}\end{array}$ \\
\hline F-stat (1st stage) & 19.515 & 17.476 & 16.378 \\
\hline
\end{tabular}

Note: This table reports the effect of the share of emigrés in the population on the share of civil servants in the workforce during the 19th century where the IV is the squared standardized deviation from summer temperature in 1792. All the dependent variables are in logarithm. Robust standard errors are reported in brackets. ${ }^{* * *}$ significant at the $1 \%$ level, ${ }^{* *}$ at the $5 \%$ level, ${ }^{*}$ at the $10 \%$ level. 
Table D.17: Emigrés and Octroi Tax Rates, 1875

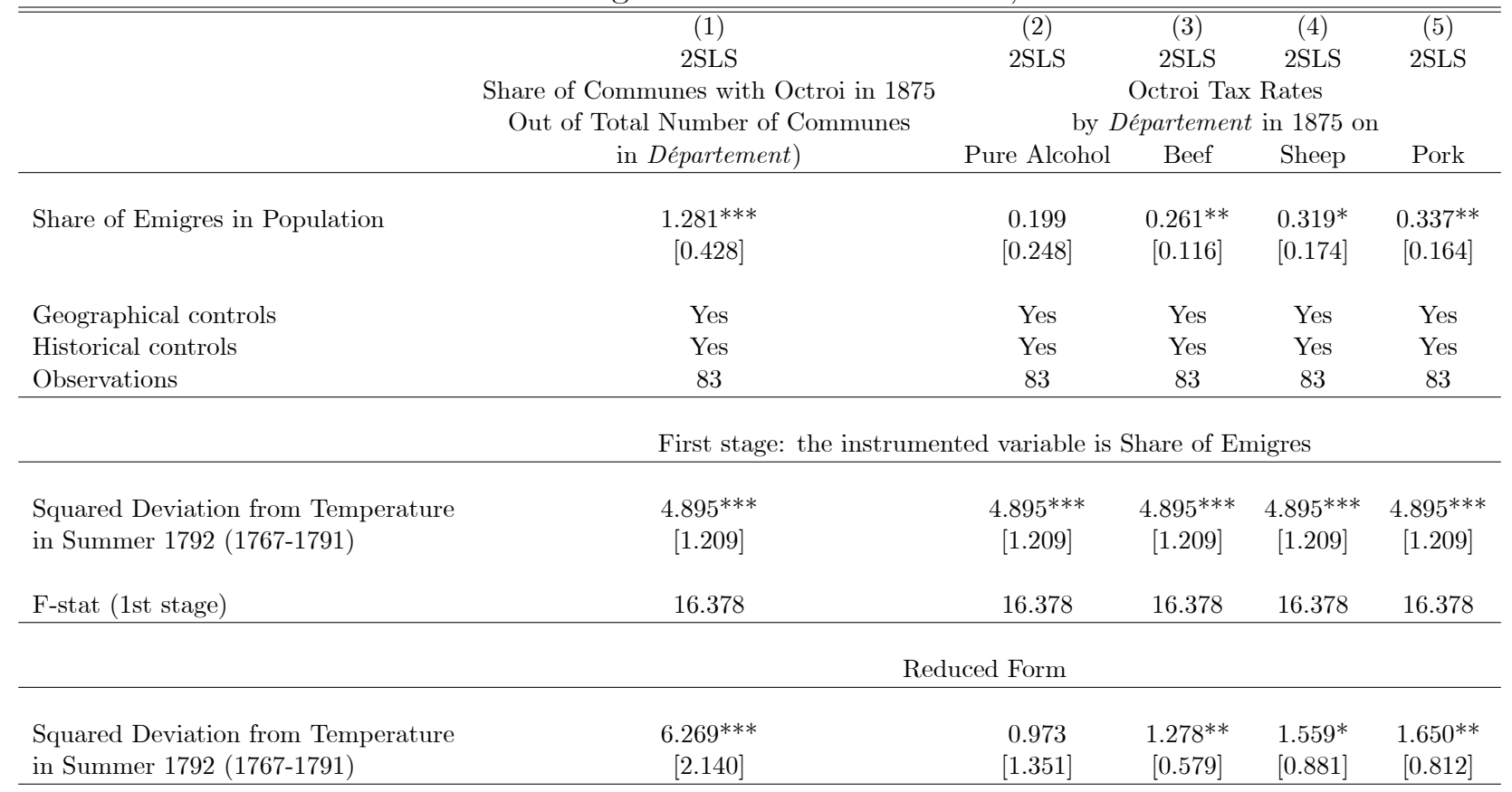

Note: This table reports the effect of the share of émigrés in the population on the share of communes with an octroi in each département in 1875 as well as on the tax rates on several goods in 1875 where the IV is the squared standardized deviation from summer temperature in 1792. All the dependent variables are in logarithm. Robust standard errors are reported in brackets. $* * *$ significant at the $1 \%$ level, $* *$ at the $5 \%$ level, * at the $10 \%$ level. 
Table D.18: Emigrés and Public Spending before World War I Panel A. Primary schools and male \& female population age 5-15

\begin{tabular}{|c|c|c|c|c|c|c|}
\hline & (1) & $(2)$ & (3) & (4) & (5) & (6) \\
\hline & 2SLS & 2SLS & 2SLS & 2SLS & 2SLS & 2SLS \\
\hline & \multicolumn{6}{|c|}{ Ratio of schools to male and female population age 5-15 } \\
\hline & 1876 & 1881 & 1886 & 1891 & 1896 & 1901 \\
\hline \multirow[t]{2}{*}{ Share of Emigres } & $-0.387^{* *}$ & $-0.407^{* *}$ & $-0.389^{* *}$ & $-0.335^{*}$ & -0.277 & $-0.427 * * *$ \\
\hline & {$[0.156]$} & {$[0.167]$} & {$[0.157]$} & {$[0.183]$} & {$[0.187]$} & {$[0.156]$} \\
\hline Geographic controls & Yes & Yes & Yes & Yes & Yes & Yes \\
\hline Historical controls & Yes & Yes & Yes & Yes & Yes & Yes \\
\hline \multirow[t]{2}{*}{ Observations } & 83 & 83 & 82 & 82 & 83 & 83 \\
\hline & \multicolumn{6}{|c|}{ First Stage: the instrumented variable is Share of Emigres } \\
\hline Squared Deviation from Temperature & $4.895^{* * *}$ & $4.895^{* * *}$ & $4.893^{* * *}$ & $4.811^{* * *}$ & $4.895^{* * *}$ & $4.895^{* * *}$ \\
\hline in Summer $1792(1767-1791)$ & {$[1.209]$} & {$[1.209]$} & {$[1.210]$} & {$[1.239]$} & [1.209] & [1.209] \\
\hline F-stat (1st stage) & 16.378 & 16.378 & 16.359 & 15.065 & 16.378 & 16.378 \\
\hline
\end{tabular}

Panel B. Total Public Spending on Education per Pupil in Primary Schools

\begin{tabular}{lccccccc}
\multicolumn{7}{c}{ Panel B. Total Public Spending on Education per Pupil in Primary Schools } \\
\hline \hline & $(1)$ & $(2)$ & $(3)$ & $(4)$ & $(5)$ & $(6)$ \\
& $2 S L S$ & 2SLS & 2SLS & 2SLS & 2SLS & 2 2SLS \\
& 1876 & 1881 & 1886 & 1891 & 1896 & 1901 \\
\hline \multirow{2}{*}{$\begin{array}{c}\text { Total Public Spending per Pupil } \\
\text { Share of Emigres }\end{array}$} & 0.0005 & $-0.184^{*}$ & -0.133 & $-0.393^{* *}$ & -0.127 & $-0.358^{* *}$ \\
& {$[0.0971]$} & {$[0.102]$} & {$[0.0908]$} & {$[0.165]$} & {$[0.103]$} & {$[0.139]$} \\
Geographic controls & Yes & Yes & Yes & Yes & Yes & Yes \\
Historical controls & Yes & Yes & Yes & Yes & Yes & Yes \\
Observations & 83 & 83 & 83 & 83 & 83 & 83 \\
\hline
\end{tabular}

First Stage: the Instrumented variable is Share of Emigres

\begin{tabular}{lccccccc}
\hline & & & & & & \\
Squared Devation from Temperature & $4.895^{* * *}$ & $4.895^{* * *}$ & $4.895^{* * *}$ & $4.895^{* * *}$ & $4.895^{* * *}$ & $4.895^{* * *}$ \\
in Summer 1792 (1767-1791) & {$[1.209]$} & {$[1.209]$} & {$[1.209]$} & {$[1.209]$} & {$[1.209]$} & {$[1.209]$} \\
& & & & & & & \\
& & 16.378 & 16.378 & 16.378 & 16.378 & 16.378 & 16.378 \\
\hline
\end{tabular}

\begin{tabular}{|c|c|c|c|c|c|c|c|c|c|}
\hline \multicolumn{10}{|c|}{ Panel C. Roads \& Railroads } \\
\hline & (1) & (2) & (3) & (4) & (5) & $(6)$ & (7) & (8) & (9) \\
\hline & 2SLS & 2SLS & 2SLS & 2SLS & 2SLS & 2SLS & 2SLS & 2SLS & 2SLS \\
\hline & \multicolumn{3}{|c|}{$\begin{array}{l}\text { Area Covered by Roads } \\
\text { within Department'sTerritory }\end{array}$} & \multicolumn{3}{|c|}{$\begin{array}{l}\text { Area Covered by Railroad } \\
\text { within Department'sTerritory }\end{array}$} & \multicolumn{3}{|c|}{$\begin{array}{l}\text { Total Spending on } \\
\text { Road Maintenance }\end{array}$} \\
\hline & 1881 & 1900 & 1913 & 1881 & 1900 & 1913 & 1881 & 1900 & 1913 \\
\hline Share of Emigres & $\begin{array}{c}-0.526^{* * *} \\
{[0.160]}\end{array}$ & $\begin{array}{c}-0.447^{* * *} \\
{[0.143]}\end{array}$ & $\begin{array}{c}-0.671^{* * *} \\
{[0.225]}\end{array}$ & $\begin{array}{c}-0.443^{* *} \\
{[0.223]}\end{array}$ & $\begin{array}{l}-0.172 \\
{[0.130]}\end{array}$ & $\begin{array}{l}-0.155 \\
{[0.117]}\end{array}$ & $\begin{array}{l}-0.153 \\
{[0.179]}\end{array}$ & $\begin{array}{c}-0.587^{* * *} \\
{[0.175]}\end{array}$ & $\begin{array}{c}-0.417^{* * *} \\
{[0.134]}\end{array}$ \\
\hline Geographic controls & Yes & Yes & Yes & Yes & Yes & Yes & Yes & Yes & Yes \\
\hline Historical controls & Yes & Yes & Yes & Yes & Yes & Yes & Yes & Yes & Yes \\
\hline Observations & 83 & 83 & 83 & 83 & 83 & 83 & 83 & 83 & 83 \\
\hline & \multicolumn{9}{|c|}{ First Stage: the Instrumented variable is Share of Emigres } \\
\hline $\begin{array}{l}\text { Squared Deviation from Temperature } \\
\text { in Summer } 1792 \text { (1767-1791) }\end{array}$ & $\begin{array}{c}4.895 * * * \\
{[1.209]}\end{array}$ & $\begin{array}{c}4.895 * * * \\
{[1.209]}\end{array}$ & $\begin{array}{c}4.895^{* * *} \\
{[1.209]}\end{array}$ & $\begin{array}{c}4.895^{* * *} \\
{[1.209]}\end{array}$ & $\begin{array}{c}4.895^{* * *} \\
{[1.209]}\end{array}$ & $\begin{array}{c}4.895^{* * *} \\
{[1.209]}\end{array}$ & $\begin{array}{c}4.895^{* * * *} \\
{[1.209]}\end{array}$ & $\begin{array}{c}4.895^{* * *} \\
{[1.209]}\end{array}$ & $\begin{array}{c}4.895^{* * *} \\
{[1.209]}\end{array}$ \\
\hline F-stat (1st stage) & 16.378 & 16.378 & 16.378 & 16.378 & 16.378 & 16.378 & 16.378 & 16.378 & 16.378 \\
\hline
\end{tabular}

Note: This table reports the effect of the share of émigrés in the population on measures pertaining to public spending on education per pupil (Panel A), the number of primary schools with respect to the male and female population ages 5-15 (Panel C), and the infrastructure of roads and railroads (Panel C) where the IV is the squared standardized deviation from summer temperature in 1792. All the dependent variables are in logarithm. Robust standard errors are reported in brackets. *** significant at the $1 \%$ level, $* *$ at the $5 \%$ level, * at the $10 \%$ level. 
Table D.19: Summer Temperature Shock 1792 and Religiosity before World War I: Falsification Tests

\begin{tabular}{|c|c|c|c|c|}
\hline & $\begin{array}{c} \\
\text { OLS }\end{array}$ & $\begin{array}{c}(2) \\
\text { OLS }\end{array}$ & $\begin{array}{c}(3) \\
\text { OLS }\end{array}$ & $\begin{array}{c}(4) \\
\text { OLS }\end{array}$ \\
\hline & $\begin{array}{c}\text { Share of Representatives in the lower House of Parliament } \\
\text { Against the Separation of Church \& State }\end{array}$ & $\begin{array}{r}\text { Number } \\
\text { Educational Purposes } 1856\end{array}$ & $\begin{array}{l}\text { of Religious Communities } \\
\text { Charity Purposes } 1856\end{array}$ & $\begin{array}{l}\text { Devoted to } \\
\text { Only Religious Purposes } 1856\end{array}$ \\
\hline $\begin{array}{l}\text { Squared Deviation from Temperature } \\
\text { in Summer } 1792(1767-1791)\end{array}$ & $\begin{array}{l}-0.671 \\
{[0.534]}\end{array}$ & $\begin{array}{l}-2.419 \\
{[2.131]}\end{array}$ & $\begin{array}{c}2.930 \\
{[1.903]}\end{array}$ & $\begin{array}{l}-0.254 \\
{[2.467]}\end{array}$ \\
\hline $\begin{array}{l}\text { Geographical Controls } \\
\text { Historical Controls } \\
\text { Observations }\end{array}$ & $\begin{array}{l}\text { Yes } \\
\text { Yes } \\
83\end{array}$ & $\begin{array}{l}\text { Yes } \\
\text { Yes } \\
82\end{array}$ & $\begin{array}{l}\text { Yes } \\
\text { Yes } \\
82\end{array}$ & $\begin{array}{l}\text { Yes } \\
\text { Yes } \\
82\end{array}$ \\
\hline
\end{tabular}

Note: This table reports reduced-form regressions between our IV, the squared deviation from standardized temperature in the summer of 1792 and variables which could potentially be endogenous to economic growth, and which could bias our estimates if they were correlated with our IV. These are variables pertaining to religiosity before World War I. All the dependent variables are in logarithm. Robust standard errors are reported in brackets. ${ }^{* * *}$ significant at the $1 \%$ level, ${ }^{* *}$ at the $5 \%$ level, ${ }^{*}$ at the $10 \%$ level.

Table D.20: Summer Temperature Shock 1792 and the Phylloxera: Falsification Tests

\begin{tabular}{lcc}
\hline \hline & $(1)$ & $(2)$ \\
& OLS & OLS \\
& \multicolumn{3}{c}{$\begin{array}{c}\text { Departments hit by } \\
\text { the Phylloxera in }\end{array}$} \\
& 1875 & 1890 \\
\hline & & \\
Squared Deviation from Temperature & -0.347 & -0.312 \\
in Summer 1792 (1767-1791) & {$[0.735]$} & {$[1.005]$} \\
& & \\
Geographical Controls & Yes & Yes \\
Historical Controls & Yes & Yes \\
Observations & 86 & 86 \\
\hline
\end{tabular}

Note: This table reports reduced-form regressions between our IV, the squared deviation from standardized temperature in the summer of 1792 and variables which could potentially be endogenous to economic growth, and which could bias our estimates if they were correlated with our IV. These are variables pertaining to the départements hit by the phylloxera in 1875 and 1890. All the dependent variables are in logarithm. Robust standard errors are reported in brackets. ${ }^{* * *}$ significant at the $1 \%$ level, ${ }^{* *}$ at the $5 \%$ level, ${ }^{*}$ at the $10 \%$ level. 
Table D.21: Descriptive Statistics for Variables in Robustness Analysis

\begin{tabular}{lccccc}
\hline \hline & Obs. & Mean & Std.Dev & Min. & Max. \\
Infant Mortality (Age 0-1) & & & & & \\
Infant Mortality (Age 0-1) 1811 & 85 & 0.30 & 0.08 & 0.16 & 0.53 \\
Infant Mortality (Age 0-1) 1821 & 85 & 0.29 & 0.10 & 0.14 & 0.60 \\
Infant Mortality (Age 0-1) 1831 & 85 & 0.32 & 0.09 & 0.16 & 0.53 \\
Infant Mortality (Age 0-1) 1841 & 85 & 0.27 & 0.08 & 0.14 & 0.46 \\
Infant Mortality (Age 0-1) 1851 & 85 & 0.30 & 0.08 & 0.16 & 0.48 \\
Infant Mortality (Age 0-1) 1861 & 88 & 0.29 & 0.10 & 0.12 & 0.63 \\
Infant Mortality (Age 0-1) 1871 & 86 & 0.31 & 0.08 & 0 & 0.49 \\
Infant Mortality (Age 0-1) 1881 & 86 & 0.25 & 0.08 & 0 & 0.48 \\
Infant Mortality (Age 0-1) 1891 & 86 & 0.22 & 0.06 & 0 & 0.40 \\
Infant Mortality (Age 0-1) 1901 & 86 & 0.19 & 0.04 & 0 & 0.29 \\
Infant Mortality (Age 0-1) 1911 & 86 & 0.04 & 0.01 & 0.02 & 0.07 \\
Infant Mortality (Age 0-1) 1931 & 89 & 0.07 & 0.01 & 0.01 & 0.10 \\
Coale Fertility Index & & & & & \\
Coale Fertility Index 1811 & 87 & 0.40 & 0.10 & 0.24 & 0.87 \\
Coale Fertility Index 1821 & 87 & 0.39 & 0.11 & 0.24 & 0.82 \\
Coale Fertility Index 1831 & 87 & 0.37 & 0.11 & 0.23 & 0.74 \\
Coale Fertility Index 1841 & 87 & 0.34 & 0.08 & 0.21 & 0.61 \\
Coale Fertility Index 1851 & 87 & 0.34 & 0.07 & 0.21 & 0.54 \\
Coale Fertility Index 1861 & 90 & 0.31 & 0.06 & 0.21 & 0.48 \\
Coale Fertility Index 1871 & 88 & 0.29 & 0.06 & 0.18 & 0.50 \\
Coale Fertility Index 1881 & 88 & 0.29 & 0.06 & 0.20 & 0.57 \\
Coale Fertility Index 1891 & 88 & 0.25 & 0.05 & 0.16 & 0.45 \\
Coale Fertility Index 1901 & 88 & 0.25 & 0.04 & 0.18 & 0.42 \\
Coale Fertility Index 1911 & 87 & 0.21 & 0.03 & 0.14 & 0.30 \\
Coale Fertility Index 1931 & 90 & 0.19 & 0.03 & 0.12 & 0.25 \\
\hline
\end{tabular}


Table D.22: Descriptive Statistics for Variables in Robustness Analysis

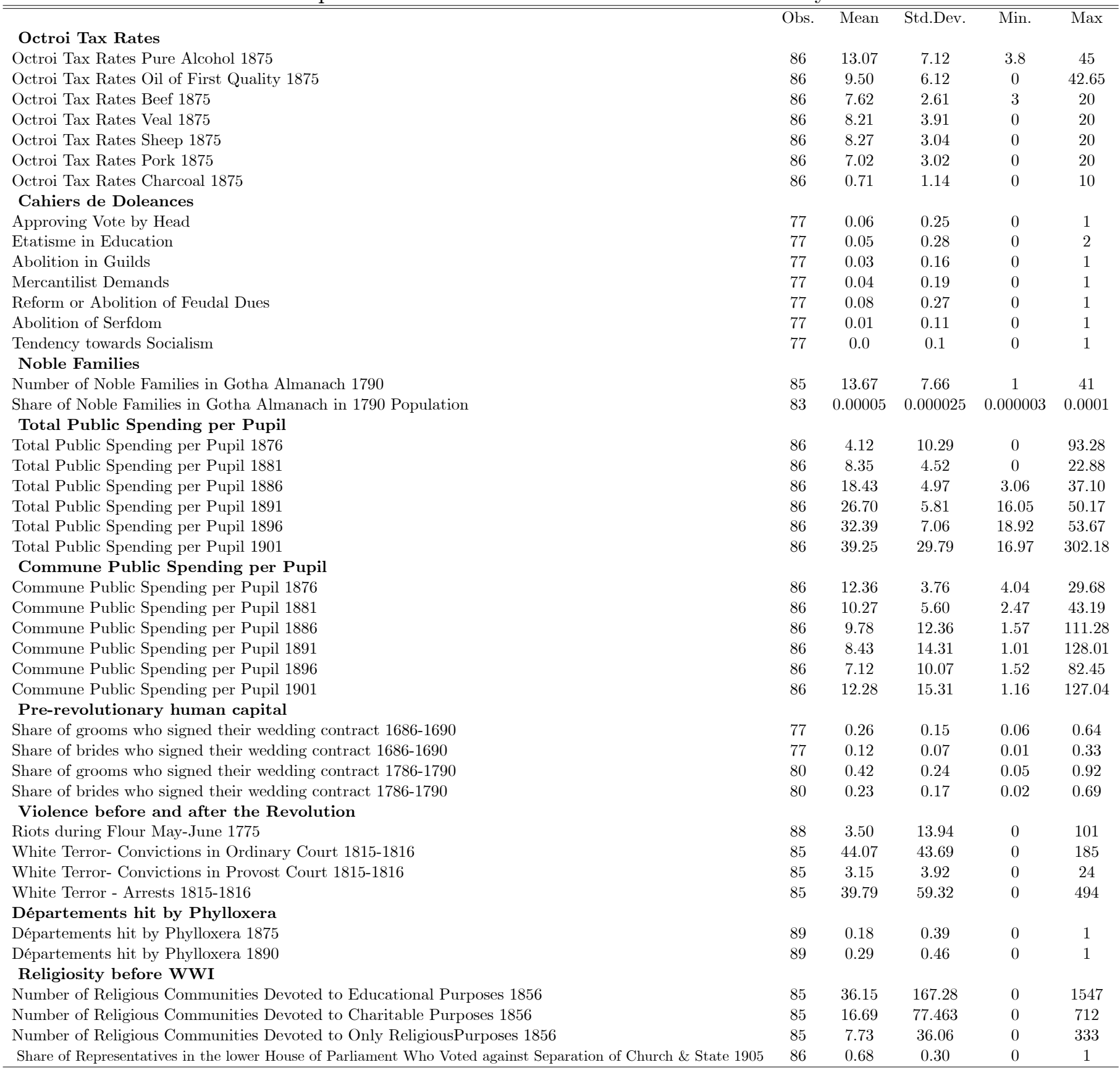


Table D.23: Descriptive Statistics for Variables in Robustness Analysis

\begin{tabular}{|c|c|c|c|c|c|}
\hline & Obs. & Mean & Std.Dev. & Min. & Max \\
\hline \multicolumn{6}{|l|}{ Population of Departement } \\
\hline Population of Departement 1801 & 85 & 641577.8 & 2933688 & 110732 & 27300000 \\
\hline Population of Departement 1821 & 86 & 706318.6 & 3249226 & 121418 & 30500000 \\
\hline Population of Departement 1841 & 86 & 793475.5 & 3651846 & 132584 & 34200000 \\
\hline Population of Departement 1861 & 89 & 837300.4 & 3925182 & 125100 & 37400000 \\
\hline Population of Departement 1881 & 87 & 862890.3 & 4005441 & 74244 & 37700000 \\
\hline Population of Departement 1901 & 87 & 892279.3 & 4150369 & 92304 & $3.90 \mathrm{E}+07$ \\
\hline Population of Departement 1921 & 89 & 876884.7 & 4138580 & 89275 & $3.92 \mathrm{E}+07$ \\
\hline Population of Departement 1968 & 88 & 593623.9 & 791113.2 & 80736 & 6648664 \\
\hline Population of Departement 1992 & 88 & 649898 & 821404.6 & 76948 & 6285496 \\
\hline Population of Departement 1999 & 88 & 698841.7 & 878124.3 & 75644 & 6340619 \\
\hline Population of Departement 2010 & 88 & 747640.3 & 942826 & 79096.9 & 6860285 \\
\hline \multicolumn{6}{|l|}{ Population of Chef-Lieu of Departement } \\
\hline Population of Chef-Lieu of Departement 1806 & 88 & 28030.7 & 70275.86 & 857 & 649412 \\
\hline Population of Chef-Lieu of Departement 1821 & 88 & 28839.17 & 71452.48 & 2792 & 657172 \\
\hline Population of Chef-Lieu of Departement 1841 & 85 & 38780.45 & 102935.3 & 4465 & 935261 \\
\hline Population of Chef-Lieu of Departement 1861 & 87 & 58251.8 & 184675.9 & 5139 & 1696141 \\
\hline Population of Chef-Lieu of Departement 1881 & 88 & 73552.09 & 245154.9 & 6749 & 2269023 \\
\hline Population of Chef-Lieu of Departement 1901 & 88 & 98459.64 & 311575.6 & 7065 & 2714068 \\
\hline Population of Chef-Lieu of Departement 1921 & 88 & 111380.4 & 353485.3 & 6109 & 2906472 \\
\hline Population of Chef-Lieu of Departement 1946 & 88 & 122694.7 & 367106 & 6010 & 2725374 \\
\hline Population of Chef-Lieu of Departement 1968 & 88 & 158219.7 & 441138.5 & 9331 & 3224442 \\
\hline Population of Chef-Lieu of Departement 1982 & 88 & 154265.8 & 427001.5 & 9282 & 3370085 \\
\hline Population of Chef-Lieu of Departement 1999 & 88 & 155334.1 & 428480.4 & 9109 & 3427738 \\
\hline Population of Chef-Lieu of Departement 2006 & 88 & 154276.4 & 435911.3 & 8681 & 3479900 \\
\hline \multicolumn{6}{|l|}{ Ratio of schools to male and female population age 5-15 } \\
\hline Ratio of schools to male and female population age 5-15 1876 & 86 & 0.013 & 0.005 & 0.004 & 0.029 \\
\hline Ratio of schools to male and female population age 5-15 1881 & 86 & 0.013 & 0.006 & 0.004 & 0.054 \\
\hline Ratio of schools to male and female population age 5-15 1886 & 85 & 0.013 & 0.004 & 0.004 & 0.028 \\
\hline Ratio of schools to male and female population age 5-15 1891 & 84 & 0.011 & 0.004 & 0.003 & 0.021 \\
\hline Ratio of schools to male and female population age 5-15 1896 & 86 & 0.014 & 0.006 & 0.003 & 0.029 \\
\hline Ratio of schools to male and female population age 5-15 1901 & 86 & 0.016 & 0.006 & 0.004 & 0.033 \\
\hline \multicolumn{6}{|l|}{ Infrastructure and Spending on Infrastructure } \\
\hline Roads in Departement's Territory 1881 (in percent) & 86 & 12.53 & 3.46 & 5.00 & 21.20 \\
\hline Roads in Departement's Territory 1900 (in percent) & 86 & 5.47 & 1.86 & 2.34 & 12.86 \\
\hline Roads in Departement's Territory 1913 (in percent) & 86 & 12.70 & 3.53 & 1.81 & 20.65 \\
\hline Area Covered by Railroad withiin Departement's Territory 1881 (in percent) & 85 & 0.62 & 0.70 & 0.14 & 5.97 \\
\hline Area Covered by Railroad withiin Departement's Territory 1901 (in percent) & 85 & 0.84 & 0.53 & 0.25 & 4.55 \\
\hline Area Covered by Railroad withiin Departement's Territory 1913 (in percent) & 85 & 1.00 & 0.65 & 0.32 & 5.91 \\
\hline Total Spending on Road Maintenance 1881 & 86 & 3101386 & 1962050 & 335044 & 16200000 \\
\hline Total Spending on Road Maintenance 1900 & 86 & 1624075 & 1062873 & 218520 & 7595945 \\
\hline Total Spending on Road Maintenance 1912 & 86 & 2757364 & 1466609 & 353330 & 8948850 \\
\hline \multicolumn{6}{|l|}{ Contracts Sealed by Notaries } \\
\hline Contrats Sealed by Notaries 1861 & 88 & 40001.82 & 18805.45 & 8644 & 139690 \\
\hline Contrats Sealed by Notaries 1901 & 85 & 31436.32 & 22222.62 & 6157 & 179727 \\
\hline Contrats Sealed by Notaries 1931 & 88 & 33577.77 & 35862.64 & 4662 & 306451 \\
\hline \multicolumn{6}{|l|}{ Total Value of Loans from Savings Banks } \\
\hline Total Value of Loans from Savings Banks 1875 & 86 & 3132973 & 2964086 & 300374 & 18500000 \\
\hline Total Value of Loans from Savings Banks 1881 & 86 & 5864920 & 5311230 & 716117 & 37400000 \\
\hline Total Value of Loans from Savings Banks 1900 & 85 & 13200000 & 15800000 & 2360311 & 139000000 \\
\hline
\end{tabular}

